
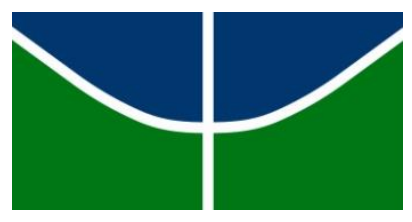

UNIVERSIDADE DE BRASÍLIA

INSTITUTO DE CIÊNCIAS BIOLÓGICAS DEPARTAMENTO DE FITOPATOLOGIA

PROGRAMA DE PÓS-GRADUAÇÃO EM FITOPATOLOGIA

\title{
ESPÉCIES DE Ralstonia NO BRASIL: CARACTERIZAÇÃO FENOTÍPICA, MOLECULAR, NOVAS FONTES DE RESISTÊNCIA EM TOMATEIRO E PATOGENICIDADE EM CAFEEIRO
}

MAURÍCIO ROSSATO

Brasília - DF

2016 


\section{MAURÍCIO ROSSATO}

ESPÉCIES DE Ralstonia NO BRASIL: CARACTERIZAÇÃO FENOTÍPICA, MOLECULAR, NOVAS FONTES DE RESISTÊNCIA EM TOMATEIRO E PATOGENICIDADE EM CAFEEIRO

Tese apresentada à Universidade de Brasília como requisito parcial para a obtenção do título de Doutor em Fitopatologia pelo Programa de Pós Graduação em Fitopatologia

\section{Orientador}

Leonardo Silva Boiteux, Ph.D.

BRASÍLIA

DISTRITO FEDERAL - BRASIL

2016 


\section{FICHA CATALOGRÁFICA}

Rossato, Maurício.

Espécies de Ralstonia no Brasil: caracterização fenotípica, molecular, novas fontes de resistência em tomateiro e patogenicidade em cafeeiro. / Maurício Rossato.

Brasília, 2016.

Número de páginas $165 \mathrm{p}$.

Tese de doutorado. Programa de Pós-graduação em Fitopatologia, Universidade de Brasília, Brasília.

1. murcha bacteriana, Ralstonia pseudosolanacearum, biovares, melhoramento.

I. Universidade de Brasília. PPG/FIT.

II. Espécies de Ralstonia no brasil: caracterização fenotípica, molecular, novas fontes de resistência em tomateiro e patogenicidade em cafeeiro. 


\section{DEDICATÓRIA}

Dedico aos meus pais, Nivaldo e Rosa, que sempre me estimularam pela busca do saber 
"None of us is as smart as all of us"

Kenneth H. Blanchard 


\section{AGRADECIMENTOS}

- Primeiramente agradeço a Deus.

- Agradeço à Capes e ao CNPq, pelo suporte financeiro durante o período do doutorado.

- Agradeço ao meu orientador, Dr. Leonardo e à Dra. Maria Esther de Noronha Fonseca que me receberam no laboratório de Melhoramento Genético da Embrapa Hortaliças e me orientaram.

- Agradeço ao Departamento de Fitopatologia da Universidade de Brasília, pelos professores excelentes e dedicados.

- Agradeço à Embrapa Hortaliças, local que convivi por 8 anos excepcionais e onde aprendi o que me permite hoje chegar ao nível de doutor. Que me forneceu espaço para desenvolvimentos pesquisas desde a minha graduação até o doutorado.

- Agradeço ao Dr. Carlos Alberto Lopes que me orientou desde o começo da minha vida acadêmica sempre indicando a forma mais ética de fazer pesquisa.

- Agradeço a todos meus amigos e mentores da Embrapa Hortaliças que me acompanharam nesse aprendizado e me auxiliaram: Amanda, Cecília, Celma, Danielle, Edivânio, Elenice, Fabiana, Fred, Luana, Luiz, Michele, Niday, Rayane, Túlio, Dra. Alice Quezado, Dr. Ailton Reis, Dr. Jadir Pinheiro e outros tantos que por aí passaram.

- Agradeço aos meus familiares que me deram suporte.

- Agradeço ao Raphael que me ajudou a trilhar esse caminho tortuoso que é a pósgraduação.

- Agradeço à minha amiga Cléia que estuda comigo desde a graduação, e que me forneceu a oportunidade de entrar na Embrapa Hortaliças para meu primeiro estágio.

- Agradeço à minha amiga Thais que me ajudou com os conhecimentos em Ralstonia e sempre foi uma boa companhia.

- Agradeço aos demais amigos que fizeram parte da minha formação e por ventura se separaram pelos caminhos da vida. 
Trabalho realizado junto ao Departamento de Fitopatologia do Instituto de Ciências Biológicas da Universidade de Brasília, sob orientação do Doutor Leonardo Silva Boiteux, com apoio da Coordenação de Aperfeiçoamento de Pessoal de Nível Superior - CAPES e do Conselho Nacional de Desenvolvimento Científico e Tecnológico - CNPq.

\title{
Espécies de Ralstonia no Brasil: Caracterização Fenotípica, Molecular, Novas Fontes de Resistência em Tomateiro e Patogenicidade em Cafeeiro
}

\section{Maurício Rossato}

TESE APROVADA em 05/10/2016 por:

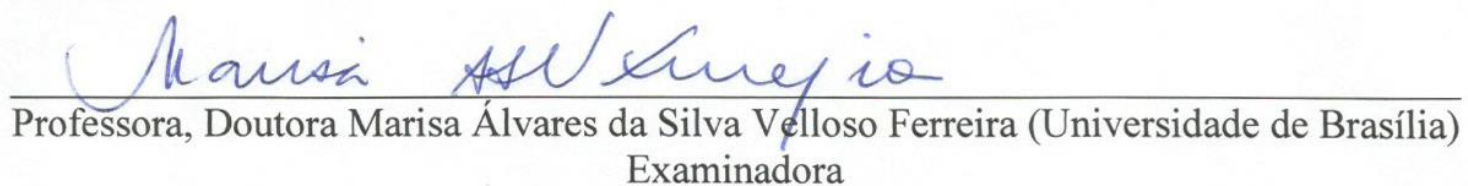

Jhoin Ribeino Soutioge

Doutora Thais Riberio Santiago (Embrapa Agroenergia)

Examinadora

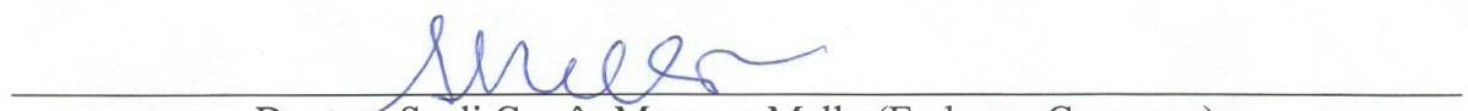

Doutora Sueli Corrêa Marques Mello (Embrapa Cenargen)

Examinadora

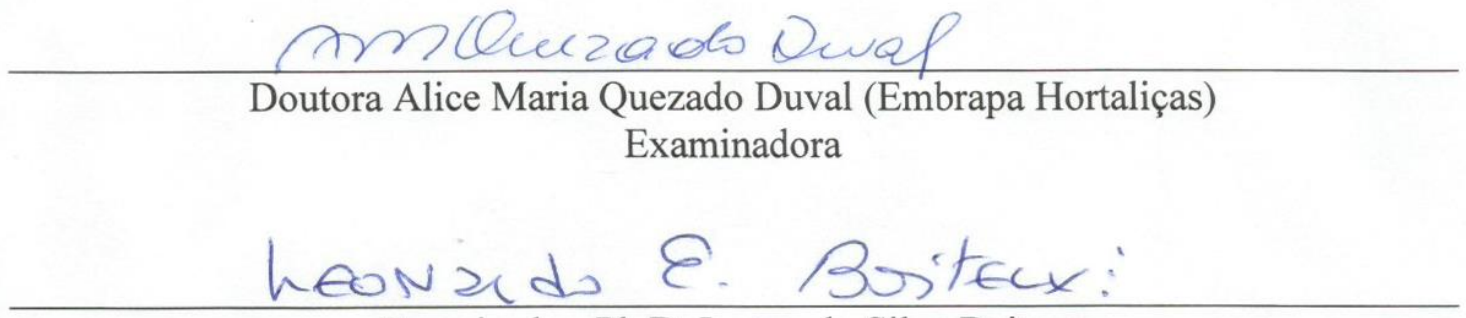

Pesquisador, Ph.D. Leonardo Silva Boiteux

Orientador (Presidente)

\author{
BRASÍLIA - DISTRITO FEDERAL \\ BRASIL




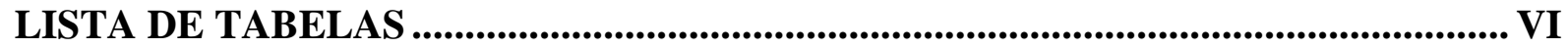

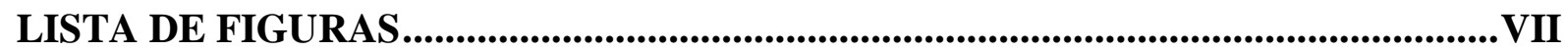

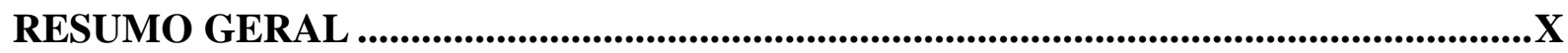

GENERAL ABSTRACT ..........................................................................................

INTRODUÇÃO GERAL E REVISÃO DE LITERATURA...............................................1

1. O PATÓGENO Ralstonia solanacearum .............................................................. 1

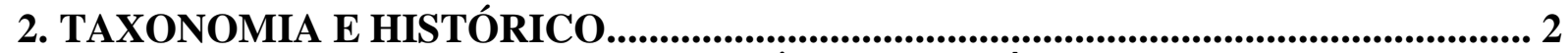

3. O GENOMA DO COMPLEXO DE ESPÉCIES DO GÊNERO Ralstonia .................... 5

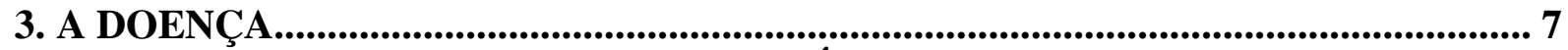

4. CONTROLE E MELHORAMENTO GENÉTICO ............................................. 8

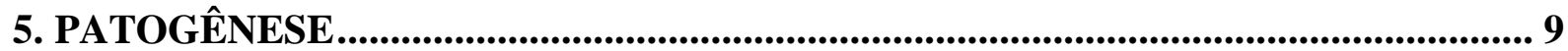

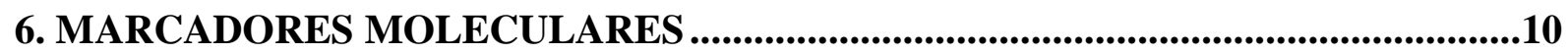

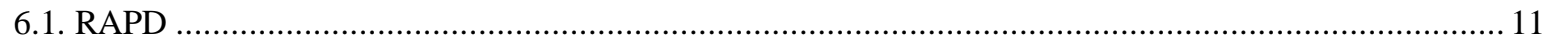

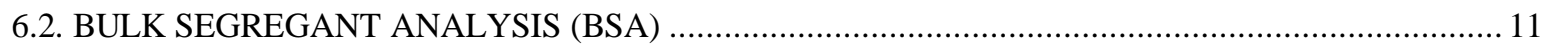

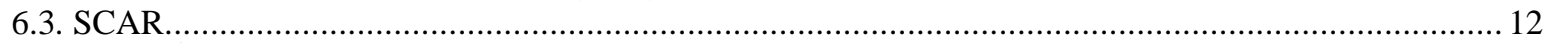

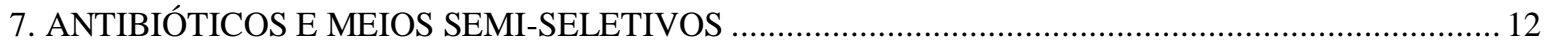

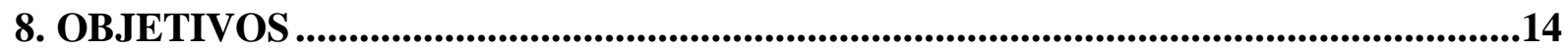

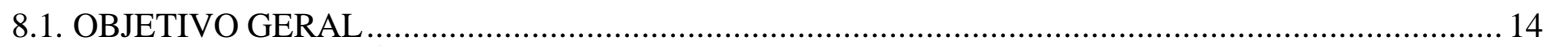

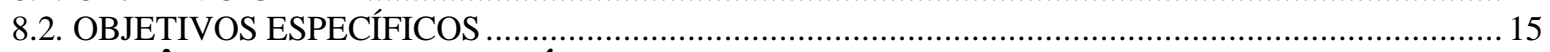

9. REFERÊNCIAS BIBLIOGRÁFICAS ....................................................................15

CARACTERIZAÇÃO DE UM ISOLADO DE Ralstonia solanacearum CAPAZ DE SUPERAR A RESISTÊNCIA DA LINHAGEM DE TOMATEIRO (Solanum

lycopersicum) 'HAWAII 7996' ...............................................................................................24

RESUMO .................................................................................................................................24

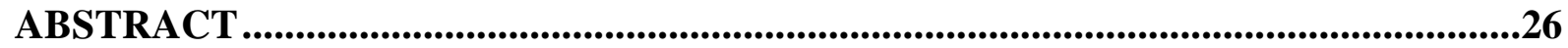

1. INTRODUÇÃO .....................................................................................................................28

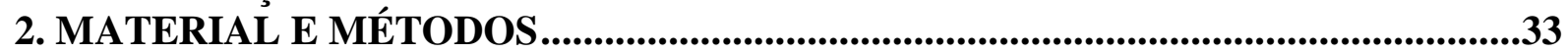

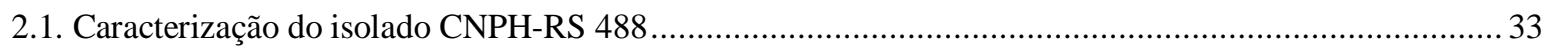

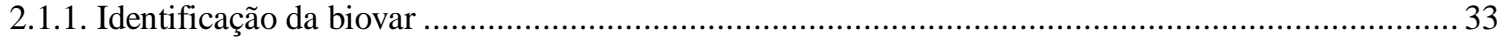

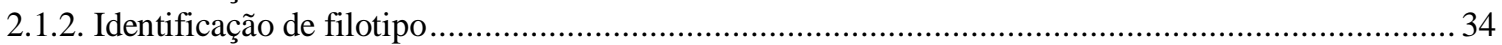

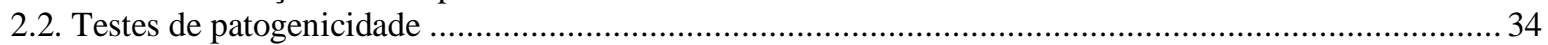

2.2.1. Teste de patogenicidade em tomateiro e batateira ........................................................................ 34

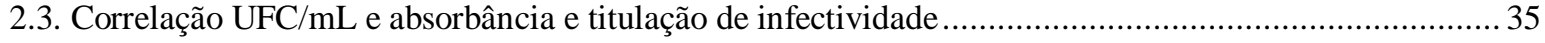

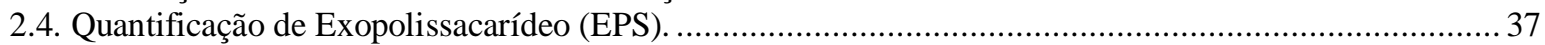

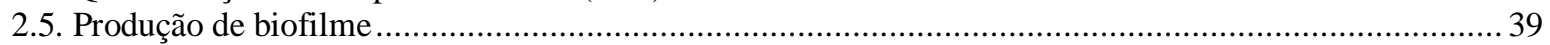

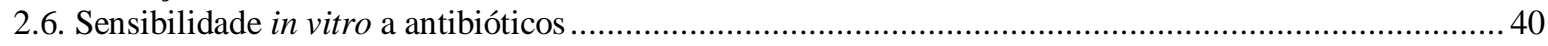

2.7. Resposta de uma gama de plantas hospedeiras a inoculações com o isolado CNPH-RS 488 .................. 40

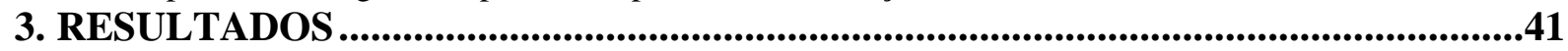

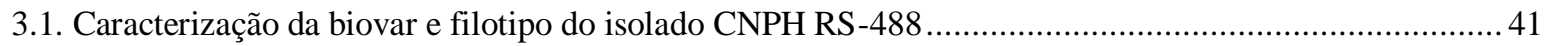

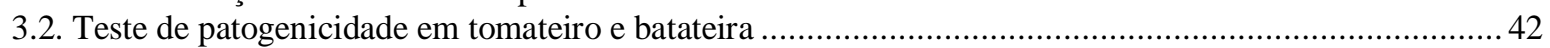

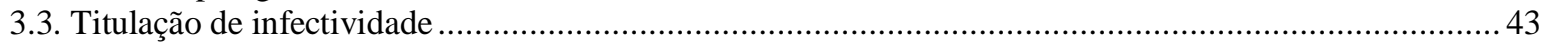

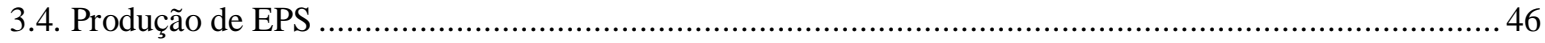

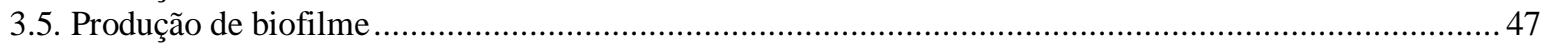

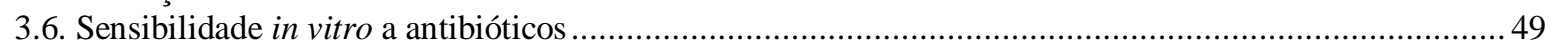

3.7. Perfil de virulência em uma gama de plantas hospedeiras .................................................................... 51

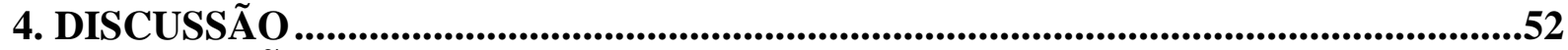

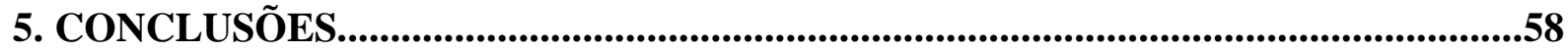




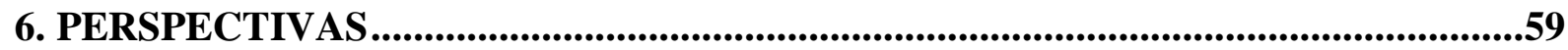

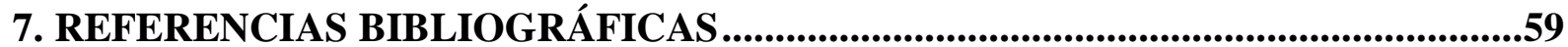

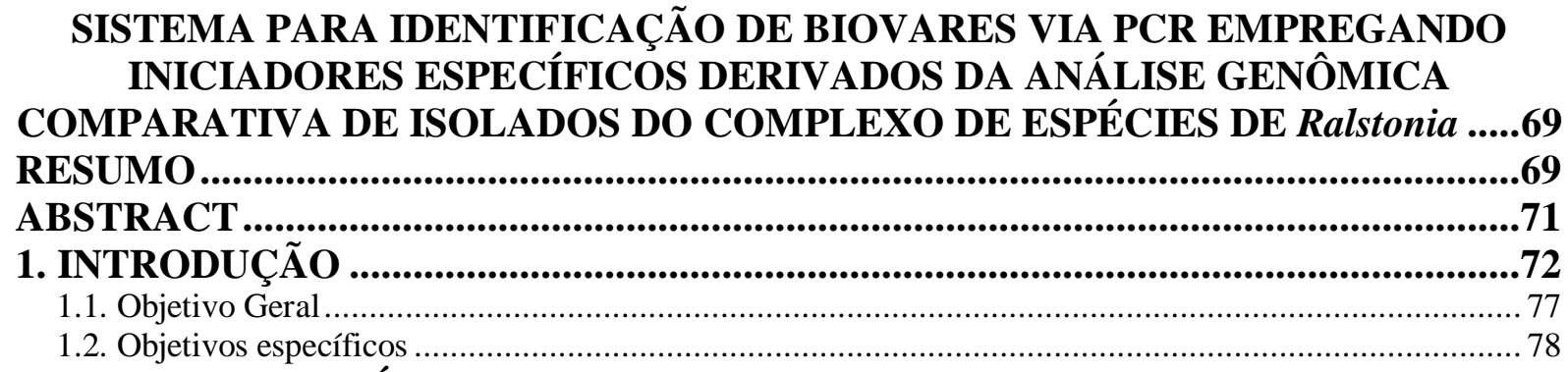

2. MATERIAL E MÉTODOS.................................................................................................78

2.1. Seleção dos isolados para estabelecimento de bulks contrastantes para as diferentes biovares ................78

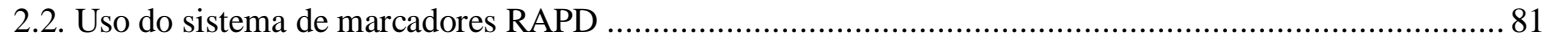

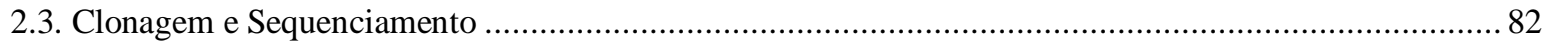

2.4. Análise de sequências dos amplicons RAPD polimórficos e desenho de primers SCARs..................... 83

2.5. Análise de sequência, identificação de regiões com identidade e localização física dos marcadores RAPD

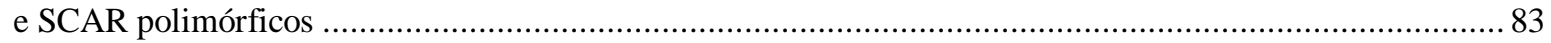

2.6. Desenvolvimento de primers específicos para o gene codificador da sorbitol desidrogenase (um dos

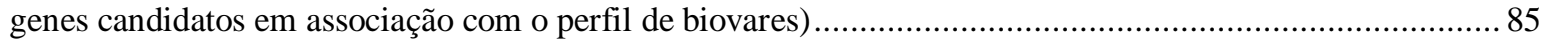

2.7. Avaliação dos primers em gradientes de temperaturas de anelamento ..............................................85

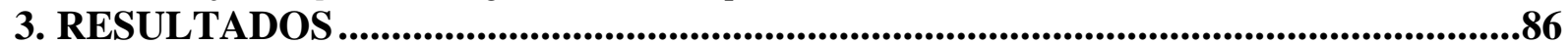

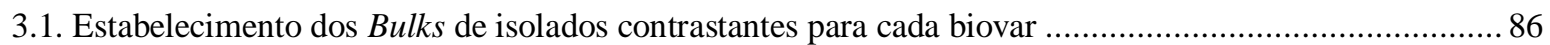

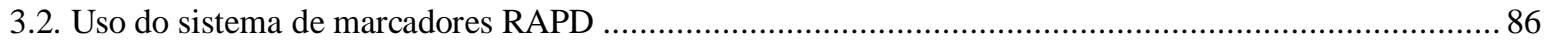

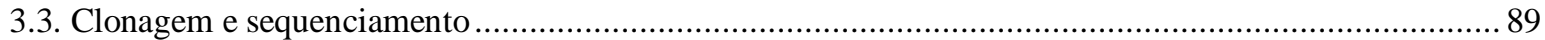

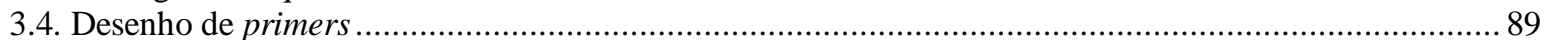

3.5. Análise das sequências dos amplicons polimórficos entre isolados contrastantes para as diferentes

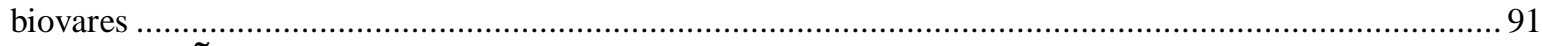

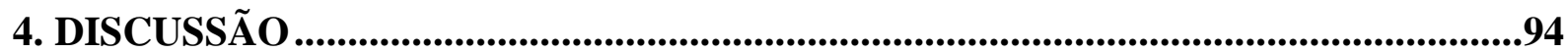

5. CONCLUSÕES.........................................................................................................99

6. PERSPECTIVAS ......................................................................................................99

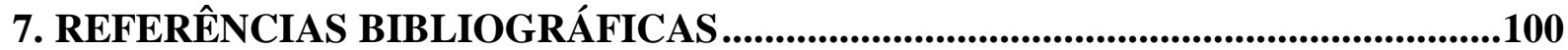

BUSCA POR FONTES DE RESISTÊNCIA A ISOLADOS DE Ralstonia solanacearum DIVERGENTES EM RELAÇÃO À CAPACIDADE DE INFECTAR A LINHAGEM

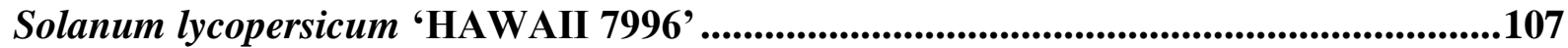

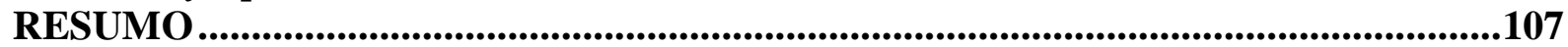

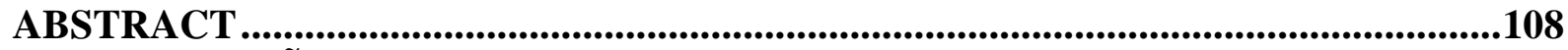

1. INTRODUÇÃ

1.1. O complexo de espécies de Ralstonia, agente causal da murcha bacteriana do tomateiro. .................. 109

1.2. O controle da murcha bacteriana via melhoramento genético ....................................................... 110

1.3. Solanum peruvianum e seu potencial como fonte de genes de resistência a doenças ............................ 111

2. MATERIAL E MÉTODOS .............................................................................113

2.1. Seleção de isolados ................................................................................................... 113

2.2. Genótipos utilizados nas avaliações............................................................................... 114

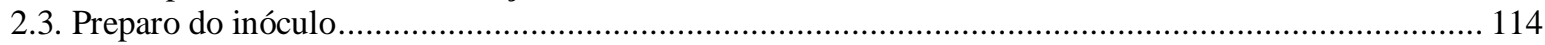

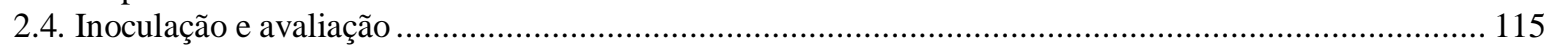

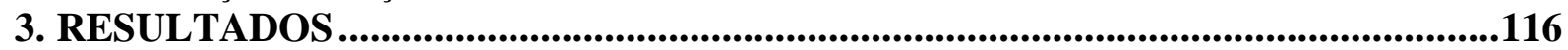

3.1. Avaliação de genótipos de tomateiro do banco de germoplasma da Embrapa Hortaliças ..................... 116

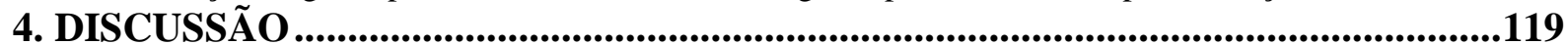

5. CONCLUSÕES..........................................................................................................122

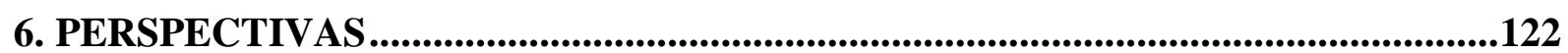


CARACTERIZAÇÃO DO CAFEEIRO (Coffea arabica - FAMÍLIA RUBIACEAE) COMO HOSPEDEIRO DE ISOLADOS DE Ralstonia pseudosolanacearum FILOTIPO

I. RESUMO

ABSTRACT

1. INTRODUÇÃO

2. MATERIAL E MÉTODOS

3. RESULTADOS

4. DISCUSSÃO

5. CONCLUSÕES

6. PERSPECTIVAS 


\section{LISTA DE TABELAS}

Tabela 1. Novas propostas de divisão do complexo de espécies do gênero Ralstonia elaboradas por dois grupos de pesquisa: Remenant et al. (2011) e Safni et al. (2014) a partir da divisão previamente proposta por Fegan \& Prior (2005).

Tabela 2. Lista de isolados do complexo de espécies de Ralstonia com genoma sequenciado e suas respectivas características.

Tabela 3. Lista de meios de cultura semi-seletivos, ano de desenvolvimento, seus respectivos componentes e antibióticos empregados.

Tabela 4. Lista de isolados do complexo de espécies de Ralstonia usados nos experimentos com suas respectivas hospedeiras, local de coleta, data do isolamento, biovar e filotipo. Isolados com origem no Brasil foram identificados com o Estado/País de origem, isolados estrangeiros foram identificados com o país de origem. .36

Tabela 5. Percentagem de plantas apresentando sintomas de murcha em testes de patogenicidade conduzidos com quatro isolados de Ralstonia solanacearum (raça 3/biovar 2). Plantas de duas linhagens de tomateiro, 'L390' (suscetível) e 'Hawaii 7996' (resistente) e da batateira suscetível 'Monalisa' foram inoculadas pelo método de penetração do caule.

Tabela 6. Resposta de sensibilidade in vitro de 48 isolados de quatro biovares (1, 2A, 2T e 3 ) do complexo de espécies de Ralstonia a 16 antibióticos e ao meio semi-seletivo SMART de (Kawanishi et al., 2011). (+) = crescimento; (-) = inibição de crescimento. Os números na tabela representam o diâmetro do halo de inibição em centímetros.

Tabela 7. Lista dos isolados do complexo de espécies de Ralstonia com genomas completos disponíveis na base de dados do GenBank e EMBL que foram utilizados em análises via subtração in silico em busca de regiões exclusivas para as diferentes biovares.

Tabela 8. Lista das biovares e os respectivos primers RAPD com polimorfismos entre as biovares do complexo de espécies de Ralstonia.

Tabela 9. Primers RAPD utilizados por biovar estudada de isolados do complexo de espécies de Ralstonia com seus respectivos amplicons.

Tabela 10. Lista dos pares de primers desenhados e dos amplicons sequenciados para marcadores gerados para cada biovar do complexo de espécies de Ralstonia, com suas respectivas características como: genoma com maior identidade com o amplicon sequenciado via análise com BLAST, anotação da região homóloga ao amplicon, porcentagem de identidade com a região homóloga, região dos amplicons correspondendo ao intervalo da sequência em que os primers anelam, e tamanho do amplicon. Tamanho amplicon SCARs se refere ao 
tamanho do fragmento gerado pelos primers SCARs, ou seja, desenhados como uma extensão do primer RAPD. O tamanho amplicon primers se refere ao fragmento gerado pelos primers desenhados internamente ao segmento sequenciado.

Tabela 11. Lista de primers desenhados a partir dos sequenciamentos de fragmentos RAPD amplificados usando DNA genômico de isolados do complexo de espécies de Ralstonia de diferentes biovares. Os primers SCAR são listados com o prefixo "SCAR", os demais foram desenhados internamente baseados em polimorfismos visualizados na subtração in silico.....91

Tabela 12. Condições utilizadas para a PCR e programa do termociclador para uso com os pares de primers J1-B1-B, SCAR-i18-B2A e Sorb-B3.

Tabela 13. Porcentagem de plantas murchas de Coffea arabica 'Catucaí', 'Catuaí Amarelo' e 'Catuaí Vermelho' (média das três cultivares) e de plantas de tomateiro 'San Vito' inoculados por imersão de raízes podadas em suspensão bacteriana de nove diferentes isolados de origens e hospedeiras diferentes.

\section{LISTA DE FIGURAS}

Figura 1. Aparência de colônias virulentas do complexo de espécies de Ralstonia nos meios de cultura. A - Meio Kelman sem tetrazólio. B - Meio Kelman com tetrazólio. C - Isolado biovar 2A com produção de pigmento marrom.

Figura 2. Gel de agarose (1\%) resultante da eletroforese dos produtos da PCR multiplex com os primers Nmult e o par 759/760 para identificação do filotipo e da espécie dos isolados CNPH-RS 461, CNPH-RS 488 e CNPH-RS 498. Eletroforese com o marcador 1kb plus, amplicon de $372 \mathrm{pb}$ indica o filotipo II. A presença do amplicon de $281 \mathrm{pb}$ confirma que o isolado é do complexo de espécies de Ralstonia.

Figura 3. Titulação de infectividade das linhagens de tomateiro 'L390' (suscetível) e 'Hawaii 7996' (resistente) avaliadas com cinco concentrações de inóculo de quatro isolados de Ralstonia solanacearum (CNPH-RS 461, CNPH-RS 488, CNPH-RS 498, CNPH-RS 534). As plantas foram avaliadas dos três até os 16 dias após a inoculação. As cores representam os resultados obtidos com as diferentes concentrações de inóculo. Eixo vertical representa o número absoluto de plantas murchas enquanto o horizontal o número de dias após a inoculação (D.A.I.). O método de Inoculação utilizado foi de borrifamento das raízes com aproximadamente $4 \mathrm{~mL}$ de suspensão bacteriana.

Figura 4. Variação na produção de exopolissacarídeo (EPS) por diferentes isolados do complexo de espécies de Ralstonia. A - Curva de calibração para estimativa da concentração 
de carboidratos totais. B - Médias das estimadas das concentrações de carboidratos totais nos diferentes isolados do complexo de espécies de Ralstonia. Médias seguidas por diferentes letras em cada coluna diferiram estatisticamente, entre si, para o teste de Scott-Knott $(5 \%$ de probabilidade).

Figura 5. Quantificação da produção de biofilme por isolados do complexo de espécies de Ralstonia de diferentes filotipos e biovares com análise estatística por teste de Scott-Knott a $5 \%$ de probabilidade.

Figura 6. Porcentagem (incidência) de plantas murchas aos 20 dias após a inoculação de seis hospedeiras (berinjela, tomate, jiló, amendoim, tagetes e gergelim) inoculadas com cinco isolados do complexo de espécies de Ralstonia.

Figura 7. Distribuição dos isolados brasileiros do complexo de espécies de Ralstonia que formaram os bulks contrastantes para as biovares 1, 2A, 2T e 3. Os triângulos verdes indicam os locais de coleta dos isolados da biovar 1, quadrados vermelhos da biovar 2A, quadrados azuis da biovar $2 \mathrm{~T}$ e círculos pretos indicam isolados da biovar 3. Lista da classificação de biovar, hospedeira original, local e ano de isolamento do conjunto de isolados do complexo de espécies de Ralstonia utilizado no estabelecimento dos bulks contrastantes para as distintas biovares e que foram analisados via Bulked segregant analysis (BSA).

Figura 8. Painel de géis de agarose mostrando o perfil de amplicons resultantes de ensaios de PCR com um conjunto de primers RAPD (Operon). Os códigos dos primers empregados estão identificados na parte superior, seguido da biovar do bulk de isolados do complexo de espécies de Ralstonia. Em vermelho estão destacados os amplicons polimórficos

Figura 9. Géis de agarose após eletroforese das reações de PCR dos 10 DNAs dos isolados do complexo de espécies de Ralstonia que compuseram os quatro bulks das biovares 1, 2A, 2T e 3 com os primers RAPD OP-A7, OP-i18, OP-J1 e OP-K10. A - Segmento do gel de eletroforese da PCR com os bulks com quadrados em azul representando os amplicons exclusivos amplificados. B - Gel de eletroforese da PCR para validação do amplicon verificado no anterior.

Figura 10. Painel de géis de eletroforese em gel de agarose com os produtos de PCR de dez isolados de cada biovar do complexo de espécies de Ralstonia com os pares de primers J1-B1B, SCAR-i18-B2A e Sorb-B3, ilustrando os níveis de especificidade de cada par.

Figura 11. Gráfico da análise da área abaixo da curva de progresso da doença (AACPD) de 75 genótipos de Solanum peruvianum avaliados quanto sua resistência à murcha bacteriana com os isolados CNPH-RS 488 (raça 3/biovar 2A) e CNPH-RS 489 (raça 1/biovar 1). Os acessos foram comparados com as linhagens 'Hawaii 7996' (controle resistente) e 'L390' (controle 
suscetível). A barra vermelha indica o resultado da linhagem suscetível ('L390') e em azul o resultado da linhagem resistente ('Hawaii 7996'). Quadros com letras indicam os grupos estatísticos formados pelo teste Scott-Knott ao nível de significância de 5\%

Figura 12. Plântulas de Coffea arabica em estágio de inoculação (com folhas cotiledonares) imersas em suspensão bacteriana de um isolado do complexo de espécies de Ralstonia. Foto: C. A. Lopes.

Figura 13. Sintomas de murcha bacteriana em plantas de cafeeiro Coffea arabica. (A) Necrose de uma das folhas cotiledonares; (B) Perda de turgidez e brilho da face adaxial foliar; (C) Evolução da perda de turgidez seguido de início de necrose da folha; (D) Fluxo bacteriano exsudando de caules seccionados de plantas de cafeeiro infectadas e sintomáticas; (E) À esquerda uma planta não inoculada e à direita planta inoculada com isolado do complexo de espécies de Ralstonia apresentando sintomas de murcha verde também com necrose em folhas mais velhas. Fotos: C. A. Lopes. 138 


\section{RESUMO GERAL}

Rossato, Maurício. Espécies de Ralstonia no Brasil: caracterização fenotípica, molecular, novas fontes de resistência em tomateiro e patogenicidade em cafeeiro. 2016. 165p. Doutorado em Fitopatologia - Universidade de Brasília, Brasília, DF.

A murcha bacteriana, atualmente reconhecida como sendo causada por um complexo de espécies do gênero Ralstonia (Ralstonia solanacearum, R. pseudosolanacearum e R. syzygii) apresenta uma ampla diversidade, podendo ser dividida em raças, biovares, filotipos e sequevares. O objetivo deste trabalho foi: (i) ampliar os conhecimentos sobre o importante complexo de espécies de Ralstonia por meio da caracterização biológica, bioquímica e molecular do isolado CNPH-RS 488, que se mostrou capaz de suplantar a resistência da linhagem 'Hawaii 7996'; (ii) gerar um novo protocolo de identificação de biovares por meio de técnicas moleculares, visando aumentar a eficiência do processo e reduzir os custos associados com o teste de biovar; (iii) identificar novas fontes de resistência em tomateiro à murcha bacteriana em germoplasma selvagem de Solanum, considerando o melhoramento antecipatório contra possíveis novos variantes do patógeno, como o isolado CNPH-RS 488; (iv) gerar informações sobre o patossistema Coffea - Ralstonia. No presente estudo, o isolado CNPH-RS 488 foi classificado quanto ao biovar e filotipo, e foram caracterizados o seu perfil de virulência, a capacidade de suplantar de resistência da linhagem 'Hawaii 7996', a produção de EPS e de biofilme, bem como a sensibilidade a antibióticos e sua gama de hospedeiras. Os sistemas de marcadores RAPD/SCAR em associação com a estratégia de bulk segregant analysis foram inicialmente empregados visando o desenvolvimento de primers específicos para identificação de biovares. Para a busca por novas fontes de resistência avaliou-se uma coleção de 75 genótipos de Solanum peruvianum em comparação com as linhagens controle 'Hawaii 7996' (resistente) e 'L390' (suscetível). Os genótipos foram inoculados com os isolados CNPH-RS 488 (biovar 2A) e CNPH-RS 489 (biovar 1). O status do cafeeiro como hospedeira do complexo 
de espécies de Ralstonia foi demonstrado em bioensaios com nove isolados em três cultivares de Coffea arabica, comparando com a resposta do tomateiro suscetível 'San Vito'. A confirmação da capacidade de suplantação da resistência do 'Hawaii 7996' pelo CNPH-RS 488 não pôde ser explicada pelos testes de produção de exopolissacarídeo e biofilme. Foi também constatado que o isolado apresenta uma maior virulência sobre espécies mais resistentes como jiló e berinjela. Onze primers RAPD foram selecionados com potencial valor diagnóstico para identificação de biovares. Amplicons obtidos com quatro primers que geraram marcadores estáveis foram clonados e a informação de sequência foi utilizada para o desenho dos primers do tipo SCAR. Os primers J1-B1-B e SCAR-i18-B2A apresentaram especificidade parcial para isolados de biovar 1 e 2A, respectivamente. Para a biovar 3, foi empregada uma estratégia de subtração in silico que permitiu o desenho de um par de primers específico para a região do gene polS (codificador da enzima sorbitol desidrogenase). Sete genótipos dos 75 de $S$. peruvianum foram considerados como promissoras fontes para o melhoramento do tomateiro visando à resistência à murcha bacteriana. $\mathrm{O}$ cafeeiro se mostrou suscetível exclusivamente a isolados de $R$. pseudosolanacearum, indicando os potenciais riscos que a murcha bacteriana pode apresentar para a cafeicultura brasileira. O presente trabalho destaca que a existência de isolados capazes de suplantar a resistência do tomateiro, como o CNPH-RS 488, e isso implica em potenciais riscos da disseminação dos mesmos pelo país, podendo inviabilizar as cultivares de tomateiro atualmente disponíveis no mercado e que usam a linhagem 'Hawaii 7996' como parental. Estudos adicionais sobre esse variante do patógeno serão necessários bem como o desenvolvimento de programas de melhoramento com novas fontes de resistência efetivas contra isolados com um perfil de virulência similar ao apresentado pelo CNPH-RS 488.

Palavras-chave: biovares, murcha bacteriana, suplantação de resistência, SCAR, Solanum peruvianum. 


\section{GENERAL ABSTRACT}

\section{Rossato, Maurício. Ralstonia species in Brazil: Phenotypical and molecular}

characterization, new sources of resistance in tomato and pathogenicity to coffee plants. 2016. 165p. Doctorate in Plant Pathology - Universidade de Brasília, Brasília, DF.

The bacterial wilt is currently recognized as being caused by a complex of three species: Ralstonia solanacearum, R. pseudosolanacearum, and $R$. syzygii. The causal agents of the bacterial wilt display a wide diversity, being classified in races, biovars, phylotypes, and sequevars. The objective of the present thesis was: (i) add new information about this important bacterial complex via biological, biochemical and molecular characterization of the isolate $R$. solanacearum CNPH-RS 488, which was found to be able to break down the resistance of the tomato (Solanum lycopersicum) inbred line 'Hawaii 7996'; (ii) develop a new protocol for molecular characterization of biovars, focusing on making a faster and cheaper biovar identification test; (iii) search for new sources of resistance to bacterial wilt disease within a germplasm collection of wild Solanum (section Lycopersicon) species, using the preemptive breeding and developing new resistant cultivar to new and atypical strains like the CNPH-RS 488; (iv) study and characterize a new pathosystem: Coffea-Ralstonia. Studies with the isolate R. solanacearum CNPH-RS 488 involved different approaches: (1) determination of its biovar and phylotype; (2) determination of its virulence profile, including the capability of breaking down the resistance of 'Hawaii 7996'; (3) production of exopolysaccharides (EPS) and biofilm; (4) antibiotic sensitivity, and (5) host range. The RAPD/SCAR marker systems in association with bulk segregant analysis was the strategy initially employed aiming to develop biovarspecific PCR-based markers. The search for new sources of resistance to bacterial wilt was carried using 75 Solanum peruvianum accessions and two standard lines 'Hawaii 7996' (resistant) and 'L390' (susceptible). Bioassays were carried out with two isolates, CNPH-RS 488 (biovar 2A) and CNPH-RS 489 (biovar 1). For the study of coffee as a host of the Ralstonia 
species complex, plants of three $C$. arabica cultivars were inoculated with a collection of nine isolates and their reactions were compared with that of the susceptible standard (tomato 'San Vito'). The 'Hawaii 7996'-resistant breaking ability of the isolate CNPH-RS 488 could not be explained by EPS and biofilm production. In addition, it was found that this isolate displayed a wider virulence profile being also able to infect accessions of scarlet eggplant and eggplant (which are naturally more tolerant to bacterial wilt). Eleven RAPD primers with potential diagnostic value for biovar were selected. Four stable amplicons (generated by four RAPD primers) were gel-purified and cloned. The sequence information was used for the design of SCAR-like primers. The primers J1-B1-B and SCAR-i18-B2A displayed partial specificity to isolates biovar 1 and 2A, respectively. For the biovar 3, it was employed the in silico subtraction technique, which allowed the design of a pols (sorbitol dehydrogenase) gene-specific primer. Seven out of the 75 S. peruvianum accessions were considered as promising sources for future use in tomato breeding programs to bacterial wilt resistance. Coffee accessions were susceptible exclusively to $R$. pseudosolanacearum isolates, indicating the potential risk of the bacterial wilt for the Brazilian coffee production. The present work emphasizes the existence of isolates (such as the CNPH-RS 488), which are able to break down the major sources of resistance available in tomato breeding programs. The present work also points out the potential risks of the spread of isolates with similar virulence profile across the country, which may preclude the employment of 'Hawaii 7996' as parental material. More studies on these variants will be necessary aiming to help the tomato breeding programs in the search for new sources of resistance to isolates with virulence profiles similar to CNPH-RS 488.

Keywords: bacterial wilt, biovars, resistance break, SCAR, Solanum peruvianum. 


\section{INTRODUÇÃO GERAL E REVISÃO DE LITERATURA}

\section{O PATÓGENO Ralstonia solanacearum}

De acordo com a descrição de Denny \& Hayward (2001), Ralstonia solanacearum (Smith) (Yabuuchi et al., 1995) é uma bactéria bastonetiforme aeróbica, habitante do solo e pertencente à subdivisão $\beta$ das proteobactérias. A bactéria é gram-negativa, com flagelos polares, catalase e oxidase positiva (com acúmulo de poli- $\beta$-hidroxibutirato); apresenta nenhum ou pouco crescimento à $40^{\circ} \mathrm{C}$, com teste negativo para dihidrolase de arginina, liquefação de gelatina e hidrólise de amido ou esculina. Dois tipos de colônias podem surgir em meio de cultura, uma mais fluída ou mucóide (devido à produção de exopolissacarídeo) e a outra mais seca. Esse segundo tipo de colônia, mais associado à perda de virulência do isolado, quando cultivado em meio Kelman com adição de cloreto de trifenil tetrazólio cora o centro das colônias com uma coloração avermelhada (Kelman, 1954). As colônias não são fluorescentes e podem produzir pigmentos marrons em meio de cultura, em especial isolados da biovar $2 \mathrm{~A}$

(Figura 1) (Williamson et al., 2002; Horita et al., 2005).

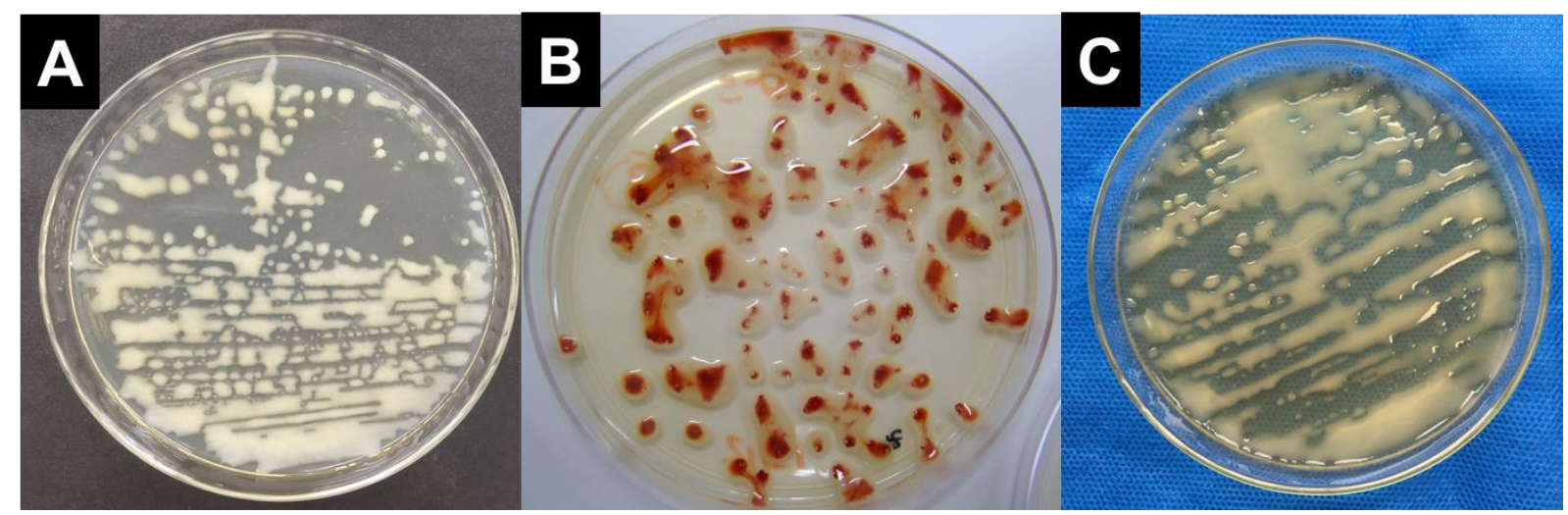

Figura 1. Aparência de colônias virulentas do complexo de espécies de Ralstonia nos meios de cultura. A - Meio Kelman sem tetrazólio. B - Meio Kelman com tetrazólio. C - Isolado biovar 2A com produção de pigmento marrom. 
Recentemente dividida em três espécies, esse complexo de patógenos pode afetar mais de 250 hospedeiras em 54 famílias botânicas (Prior et al., 2016). Existem também outras variantes, como a Ralstonia syzygii que pode ser transmitida por inseto vetor e causa a "Sumatra disease" em árvores de cravo, e a "Blood disease bacterium”, responsável por uma doença que afeta bananeiras no Velho Mundo (Prior et al., 2016). Essas duas doenças estão ausentes no Brasil.

\section{TAXONOMIA E HISTÓRICO}

O complexo de espécies de Ralstonia (CER) foi inicialmente dividido em categorias infraespecíficas, tendo a denominação de raças (Buddenhagen et al., 1962). Essa classificação de raças foge parcialmente do conceito clássico empregado na fitopatologia, uma vez que reflete a capacidade de isolados de infectar diferentes espécies vegetais e não diferentes genótipos/acessos dentro de uma mesma espécie botânica. A raça 1 é patogênica ao fumo, tomate, outras solanáceas e algumas bananas (Musa spp.) diplóides; a raça 2 é patogênica às bananas triplóides e heliconiáceas; a raça 3 é patogênica à batata, tomate, mas com baixa agressividade em outras solanáceas; a raça 4 foi reportada afetando o gengibre (Zingiber officinale Rosc., família Zingiberaceae) e raça 5, relatada em amora (gênero Rubus). As raças 4 e 5 não foram ainda detectadas no Brasil.

A classificação em biovares leva em consideração a capacidade de um isolado em utilizar e/ou oxidar álcoois (dulcitol, manitol e sorbitol) e dissacarídeos (celobiose, lactose e maltose) (Hayward, 1964; Hayward, 1994). As diferentes combinações dos compostos utilizados levam à classificação da biovar de um dado isolado. Variações para isolados de biovar 2 tropicais se caracterizam por apresentarem diferenças na temperatura necessária para indução/manifestação de sintomas, pela medida da atividade pectolítica e pelo consumo de trealose, inositol, D-ribose (Hayward, 1991b). A biovar 2T é caracterizada pela capacidade de infectar uma gama de hospedeiras mais ampla que a da biovar 2A. A biovar 2A é especialmente mais adaptada a 
batata, causando sintomas de murcha em temperaturas inferiores a $25^{\circ} \mathrm{C}$. Isolados da biovar $2 \mathrm{~A}$ aparecem, em maiores frequências que outras biovares, em associação com infecções latentes de tubérculos de batata (Hayward, 1991b).

Fegan \& Prior (2005) criaram uma nova classificação infraespecífica baseada em informações do genoma de isolados do complexo de espécies de Ralstonia. Até o momento, o sistema é composto por quatro filotipos e 57 sequevares (Wicker et al., 2012; Santiago et al., 2016). A classificação atual em filotipos se baseia na variação de tamanho de amplicons gerados da sequência ITS (intergenic transcribed spacer) do cromossomo entre os genes de RNA ribossomal 16S e 23S com os primers Nmult (Fegan \& Prior, 2005). As análises feitas por Fegan \& Prior (2005) via PCR multiplex foram validadas por hibridização genômica comparativa (Guidot et al., 2007). As sequevares compõem um nível taxonômico inferior aos filotipos e estão relacionadas com polimorfismos na sequência do gene da endoglucanase (egl) (Wicker et al., 2007). No entanto, recombinações que ocorrem com certa frequência na região do gene $e g l$ podem levar a identificações incorretas de uma sequevar quando somente esse gene é utilizado em análises filogenéticas (Prior \& Fegan, 2004; Ivey et al., 2007; Wicker et al., 2012). Desta forma, outros genes têm sido empregados para complementar a análise de sequevares, incluindo os genes mutS (proteína de reparo de DNA) e hrpB (proteína associada à patogênese e resposta hipersensível).

Recentemente duas novas propostas de divisões da espécie foram feitas. Ambas usaram abordagens distintas e alcançaram resultados similares (Tabela 1). A primeira proposta foi elaborada por Remenant et al. (2011) que dividiram as espécies usando como base os filotipos. A segunda proposta, feita por Safni et al. (2014), considerou a divisão dos filotipos criada por Fegan \& Prior (2005) e estudou a evolução do patógeno, demonstrando as similaridades genéticas entre os filotipos I e III pela média de identidade nucleotídica acima dos 95\% e agrupando-os em uma nova espécie (Ralstonia pseudosolanacearum) (Remenant et al. 2011). 
A espécie $R$. solanacearum é composta exclusivamente por isolados do filotipo II, com sítio de origem putativo no continente americano (biovar 1, 2A, 2T) (Fegan \& Prior, 2005). Isolados do filotipo IV foram classificados como subespécies de Ralstonia syzygii, seguindo a recomendação do Código internacional de nomenclatura de procariotos. Desta forma, o nome já aceito de $R$. syzygii foi mantido nesta nova proposta, ao contrário do que foi sugerido por Remenant et al. (2011).

A segunda proposta foi mais amplamente aceita pela comunidade científica, em parte por ter sido publicado no periódico mais recomendado para novos tratamentos taxonômicos, o "International Journal of Systematic and Evolutionary Microbiology" (IJSEM) e por ter seguindo as normas estabelecidas pelo Código Internacional de Nomenclatura de Procariotos. Como resultado, diversos trabalhos têm sido publicados usando as novas espécies propostas (Hida et al., 2015; Stulberg \& Huang, 2016; Zhang \& Qiu, 2016).

Tabela 1. Novas propostas de divisão do complexo de espécies do gênero Ralstonia elaboradas por dois grupos de pesquisa: Remenant et al. (2011) e Safni et al. (2014) a partir da divisão previamente proposta por Fegan \& Prior (2005).

\begin{tabular}{|c|c|c|c|c|}
\hline $\begin{array}{l}\text { Classificação } \\
\text { Clássica }\end{array}$ & $\begin{array}{c}\text { Fegan \& } \\
\text { Prior, 2005 }\end{array}$ & Biovar & $\begin{array}{c}\text { Remenant et al. } \\
2011\end{array}$ & Safni et al., 2014 \\
\hline \multirow{4}{*}{$\begin{array}{c}\text { Ralstonia } \\
\text { solanacearum }\end{array}$} & Filotipo I & $3,4,5$ & $\begin{array}{l}\text { Ralstonia } \\
\text { sequeirae }\end{array}$ & $\begin{array}{l}\text { Ralstonia } \\
\text { pseudosolanacearum }\end{array}$ \\
\hline & Filotipo II & $\begin{array}{c}1,2 \mathrm{~A} \\
2 \mathrm{~T}\end{array}$ & $\begin{array}{l}\text { Ralstonia } \\
\text { solanacearum }\end{array}$ & $\begin{array}{l}\text { Ralstonia } \\
\text { solanacearum }\end{array}$ \\
\hline & Filotipo III & $1,2 \mathrm{~T}$ & $\begin{array}{l}\text { Ralstonia } \\
\text { sequeirae }\end{array}$ & $\begin{array}{l}\text { Ralstonia } \\
\text { pseudosolanacearum }\end{array}$ \\
\hline & Filotipo IV & 1,2 & $\begin{array}{l}\text { Ralstonia } \\
\text { haywardii subsp. } \\
\text { solanacearum }\end{array}$ & $\begin{array}{l}\text { Ralstonia syzygii } \\
\text { subsp. indonesiensis }\end{array}$ \\
\hline $\begin{array}{l}\text { Ralstonia } \\
\text { syzygii }\end{array}$ & Filotipo IV & - & $\begin{array}{l}\text { Ralstonia } \\
\text { haywardii subsp. } \\
\text { syzygii }\end{array}$ & $\begin{array}{l}\text { Ralstonia syzygii } \\
\text { subsp. syzygii }\end{array}$ \\
\hline BDB & Filotipo IV & - & $\begin{array}{l}\text { Ralstonia } \\
\text { haywardii subsp. } \\
\text { celebensis }\end{array}$ & $\begin{array}{l}\text { Ralstonia syzygii } \\
\text { subsp. celebensis }\end{array}$ \\
\hline
\end{tabular}




\section{O GENOMA DO COMPLEXO DE ESPÉCIES DO GÊNERO Ralstonia}

Um grande avanço nos conhecimentos sobre o CER foi obtido após o sequenciamento completo do genoma completo do isolado GMI1000 (Salanoubat et al., 2002). A partir daí a evolução de técnicas de sequenciamento e a redução de custos permitiram o sequenciamento de mais de 50 genomas completos de diferentes isolados (Tabela 2), a maioria ainda em processo de finalização de anotação (draft). Entre esses isolados encontram-se representados diferentes filotipos, biovares, raças e sequevares, permitindo diversas análises comparativas com o genoma de referência (Salanoubat et al., 2002; Safni et al., 2014; Prior et al., 2016).

Uma característica do genoma que se mostrou conservada nos isolados do CER analisados é a presença de dois replicons circulares constituídos de um cromossomo de 3,7 megabases e um megaplasmídeo de 2,1 megabases (Salanoubat et al., 2002; Genin \& Boucher, 2004). O maior replicon, também chamado de cromossomo, carrega características clássicas dos genomas bacterianos, associados à origem de replicação e outros genes constitutivos (housekeeping). O replicon menor apresenta uma presumível origem plasmidial devido à quantidade de genes repA próximos ao sítio de replicação.

Tabela 2. Lista de isolados do complexo de espécies de Ralstonia com genoma sequenciado e suas respectivas características.

\begin{tabular}{lcclll}
\multicolumn{1}{c}{ Isolado } & Filot/Seq & Biovar & \multicolumn{1}{c}{ Hospedeira } & \multicolumn{1}{c}{ Origem } & \multicolumn{1}{c}{ Acesso } \\
$\begin{array}{l}\text { FJAT-1458- } \\
\text { avir }\end{array}$ & 1 & - & $\begin{array}{l}\text { Tomate } \\
\text { Assintomático }\end{array}$ & China & GenBank: AHIX00000000.1 \\
FJAT-91 & 1 & 3 & Tomate & China & GenBank: AHIY00000000 \\
FQY_4 & I & 3 & Solo & China & GenBank: CP004012, CP004013 \\
Rs-09-161 & I & 3 & Berinjela & Índia & GenBank: NZ_CM002757.1, NZ_CM002758.1 \\
Rs-10-244 & I & 3 & Pimenta & Índia & GenBank: NZ_CM002755.1, NZ_CM002756.1 \\
Y45 & I & 3 & Fumo & China & GenBank: AFWL00000000 \\
SD54 & I-16 & 4 & Gengibre & China & GenBank: ASQR00000000.2
\end{tabular}




\begin{tabular}{|c|c|c|c|c|c|}
\hline GMI1000 & $\mathrm{I}-18$ & 3 & Tomate & $\begin{array}{l}\text { Guiana } \\
\text { Francesa }\end{array}$ & GenBank: NC_003295, NC_003296 \\
\hline NCPPB282 & II-2 & 2 & Batata & Colômbia & GenBank: JQSH00000000.1 \\
\hline 23-10BR & II-27 & 2 & Batata & Brasil & GenBank: JQOI00000000.1 \\
\hline P673 & II-4 & 1 & $\begin{array}{l}\text { Epipremnum } \\
\text { aureum }\end{array}$ & $\begin{array}{l}\text { Estados } \\
\text { Unidos }\end{array}$ & GenBank: JALO01000000 \\
\hline B50 & IIA-24 & 1 & Banana & Brasil & EMBL: PRJEB7421 \\
\hline IBSBF1900 & IIA-24 & 1 & Banana & Brasil & EMBL: PRJEB8309 \\
\hline CFBP2957 & IIA-36 & 1 & Tomate & $\begin{array}{l}\text { Antilhas } \\
\text { Francesas }\end{array}$ & EMBL: FP885897, FP885907 \\
\hline Grenada 9-1 & IIA-6 & 1 & Banana & Granada & EMBL: PRJEB7428 \\
\hline UW181 & IIA-6 & 1 & Banana da Terra & Venezuela & EMBL: PRJEB8309 \\
\hline K60T & IIA-7 & 1 & Tomate & $\begin{array}{l}\text { Estados } \\
\text { Unidos }\end{array}$ & EMBL: CAGT01000001 \\
\hline CFIA906 & IIB & 2 & - & - & GenBank: JNVP00000000.3 \\
\hline CFBP3858 & IIB-1 & 2 & Batata & Holanda & EMBL: PRJEB8309 \\
\hline IPO1609 & IIB-1 & 2 & Batata & Holanda & GenBank: CU914168, CU914166 \\
\hline NCPPB909 & IIB-1 & 2 & - & Egito & GenBank: JNGD00000000.1 \\
\hline POPS2 & IIB-1 & 2 & - & China & GenBank: JQSI00000000.1 \\
\hline $\mathrm{RS} 2$ & IIB-1 & 2 & Batata & Bolívia & EMBL: PRJEB8309 \\
\hline UY031 & IIB-1 & 2 & Batata & Uruguai & GenBank: NZ_CP012687.1, NZ_CP012688.1 \\
\hline CFBP1416 & IIB-3 & 1 & Banana da Terra & Costa Rica & EMBL: PRJEB7434 \\
\hline CIP417 & IIB-3 & 1 & Banana & Filipinas & EMBL: PRJEB7427 \\
\hline MolK2 & IIB-3 & 1 & Banana & Filipinas & GenBank: CAHW01000040 \\
\hline CFBP6783 & IIB-4 & 1 & Helicônia & $\begin{array}{l}\text { Antilhas } \\
\text { Francesas }\end{array}$ & EMBL: PRJEB7432 \\
\hline IBSBF1503 & IIB-4 & 1 & Pepino & Brasil & EMBL: PRJEB7433 \\
\hline Po82 & IIB-4 & 1 & Batata & México & GenBank: CP002819, CP002820 \\
\hline UW163 & IIB-4 & 1 & Banana da Terra 1 & Peru & EMBL: PRJEB7430 \\
\hline CFBP7014 & IIB-59 & 1 & Antúrio & Trinidad & EMBL: PRJEB8309 \\
\hline
\end{tabular}


$\begin{array}{llllll}\text { CMR15 III } & 1 & \text { Tomate } & \text { Camarões } & \text { EMBL: FP885895, FP885896 }\end{array}$

$\begin{array}{lllll}\text { PSI07 IV } & 2 & \text { Tomate } & \text { Indonésia } & \text { EMBL: FP885906, FP885891 }\end{array}$

“_“ dado não conhecido.

\section{A DOENÇA}

A murcha bacteriana é considerada um fator limitante na produção de diversas culturas, estando amplamente distribuída em regiões tropicais, subtropicais e temperadas do mundo (Hayward, 1991a). É um patógeno cosmopolita que não se restringe a alguns grupos de hospedeiras, podendo afetar plantas daninhas, plantas cultivadas, arbustivas e árvores, tanto monocotiledôneas como dicotiledôneas (Genin \& Denny, 2012). No Brasil, a doença foi relatada pela primeira vez por Von Parseval (1922) em plantas de fumo e batata e, atualmente, ocorre em todas as regiões do país (Lopes, 2005). Entre as principais hospedeiras, se encontram as espécies da família Solanaceae (Hayward, 1994), embora várias outras famílias e espécies também sejam afetadas (Malavolta et al., 2008). A doença se caracteriza por induzir sintomas de murcha verde que se manifestam nas horas mais quentes do dia, simulando, inicialmente, uma resposta a um estresse hídrico (Lopes, 2005). Com o desenvolvimento da doença os sintomas de murcha se tornam irreversíveis ou permanentes. O sintoma de murcha pode ser explicado pela ação do patógeno na planta, causando entupimento de vasos xilemáticos tanto pelas células bacterianas como também pela produção de exopolissacarídeos (Saile et al., 1997; Huang \& Allen, 2000; Tans-Kersten et al., 2001). Com as perspectivas em relação ao aquecimento global, provavelmente alguns variantes mais adaptados às temperaturas mais elevadas ganharão mais importância e é possível também que venha a se tornar mais destrutivo nas regiões em que ocorre e/ou que passe a causar danos em regiões ainda sem condições ambientais adequadas para seu desenvolvimento (Jeong et al., 2007).

Os cafeeiros (Coffea spp.) são um exemplo de espécies hospedeiras que podem ganhar importância quanto suas perdas para a murcha bacteriana (Lopes et al., 2009). A observação da 
estreita relação fillogenética entre as famílias Rubiaceae e Solanaceae (Lin et al., 2005) estimulou a condução de ensaios para verificar, a nível experimental, a potencial ocorrência do patossistema cafeeiro - Ralstonia. Os resultados foram positivos indicando a interação entre isolados do patógeno e as espécies hospedeiras do gênero Coffea.

\section{CONTROLE E MELHORAMENTO GENÉTICO}

A murcha bacteriana causada pelo CER afeta importante culturas como tomate (Solanum lycopersicum), batata (Solanum tuberosum), amendoim (Arachis hypogaea) e banana (Musa spp.) (Elphinstone, 2005), gerando grandes perdas especialmente em condições de cultivo protegido (Lopes, 2015). O controle dessa doença é especialmente complexo devido a uma somatória de características biológicas e epidemiológicas deste grupo de patógenos tais como: sobrevivência por longos períodos no solo (Lin et al., 2009), ampla gama de plantas hospedeiras (Genin \& Denny, 2012) e enorme capacidade de dispersão, por material vegetativo, cursos de água, solo contaminado e outros (Hayward, 1991a). A murcha bacteriana causada pelo CER pode obrigar a substituição da espécie cultivada, principalmente em regiões tropicais (Takatsu \& Lopes, 1997). Poucas práticas agrícolas resultam em controle eficiente, com exceção do cultivares resistentes, que em geral apresenta alta eficiência de controle, baixo custo, não exigindo conhecimentos extensos do usuário e sendo mais interessante no ponto de vista ecológico (Strange \& Scott, 2005; Jianwei et al., 2010; Wang et al., 2013; Hanson et al., 2016; Zhao et al., 2016).

A linhagem de tomateiro (Solanum lycopersicum) 'Hawaii 7996' tem sido empregada como padrão de resistência à murcha bacteriana e tem sido usada como parental para cruzamentos e diretamente como porta-enxerto (Wang et al., 2013; Lopes et al., 2015). Diversos experimentos têm confirmando sua eficiência contra uma ampla gama de isolados (Wang et al., 1998; Wang et al., 2013). A resistência nessa linhagem apresenta controle genético complexo (poligênico), sendo determinada por diferentes quantitative trait loci 
(QTLs), localizados em diferentes cromossomos (Wang et al., 1998; Carmeille et al., 2006a; Lebeau et al., 2011; Wang et al., 2013).

Mais de 40 genes de resistência já foram usados em programas de melhoramento originários de espécies silvestres do gênero Solanum (Rick \& Chetelat, 1995). Dessa forma, outras espécies do gênero Solanum podem ser potencialmente empregadas no melhoramento visando ampliar a base genética da resistência também contra a murcha bacteriana. Acessos com resistência a essa doença têm também sido identificados em acessos das espécies $S$. pennellii (Hai et al., 2008), S. pimpinellifolium (Jaworski et al., 1987) e S. peruvianum (Carmeille et al., 2006b).

\section{PATOGÊNESE}

O conhecimento detalhado dos mecanismos de patogênese associados aos patógenos causadores da murcha bacteriana é essencial quando se tem como objetivo o seu controle (Genin \& Denny, 2012). Entre os mais importantes fatores de patogênese estão o exopolissacarídeo (EPS), o biofilme e o sistema secretor do tipo III (Danhorn \& Fuqua, 2007; Genin \& Denny, 2012).

O EPS é secretado para o exterior da célula e exerce várias funções vitais tais, proteção da célula contra agentes externos (ex. antibióticos), proteção contra os sistemas de defesa da planta hospedeira (que podem detectar lipopolissacarídeos ou pili) e proteção contra o ressecamento celular (Saile et al., 1997; Murthy \& Srinivas, 2015). Outra ação também conhecida do EPS é participar do sintoma de murcha verde, auxiliando no processo de entupimento dos vasos vasculares (Milling et al., 2011). Outras potenciais implicações do EPS na patogênese foram propostas, incluindo a formação de biofilme (Genin \& Boucher, 2002; Milling et al., 2011). A rota metabólica mobilizada na produção de EPS é complexa, tendo o 
envolvimento de 12 genes presentes em um operon de 16 kb (Denny, 1995; Huang \& Schell, 1995).

A produção de biofilme é dependente de uma série de outros componentes celulares que podem determinar a velocidade ou a quantidade produzida. O pili tipo IV, por exemplo, é necessário para aderência celular necessária para ativar a síntese inicial do biofilme (Kang et al., 2002). O biofilme é composto por um conjunto diversificado de biopolímeros consistindo de polissacarídeos, proteínas, glicoproteínas, glicolipídios e pode também conter DNA extracelular (Flemming et al., 2007). O EPS é um componente importante, determinando a porosidade, a densidade, o conteúdo de água, a carga residual e estabilidade do biofilme (Flemming et al., 2007). O biofilme tem participação na patogênese devido a sua capacidade de aderência ao sistema vascular do xilema. Além disso, o biofilme pode participar da proteção celular, agindo de forma similar ao EPS, protegendo a célula bacteriana de substâncias tóxicas e evitando a detecção da bactéria pelos sistemas de defesa da planta (Bogino et al., 2013).

O sistema secretor do tipo III (SST3) apresenta características peculiares, com ativação pela detecção pela célula bacteriana de secreções externas geralmente de células hospedeiras (Cunnac et al., 2004). O mecanismo de exportação do SST3 é composto por mais de 20 diferentes proteínas, incluindo proteínas citoplasmáticas solúveis, proteínas externas de membrana e proteínas integrantes de membrana (Cunnac et al., 2004).

\section{MARCADORES MOLECULARES}

Marcadores moleculares são uma ferramenta importante para a pesquisa genética devido a sua capacidade de diferenciar e estudar variações fenotípicas e genotípicas (Moon et al., 2016). Os sistemas de marcadores moleculares (ex. RFLP, RAPD e primers específicos) tiveram participação essencial no estudo da diversidade de isolados do CER, possibilitando caracterizar algumas de suas subdivisões (Cook \& Sequeira, 1993; Genin \& Boucher, 2004; 
Prior \& Fegan, 2004). A recente popularização dos métodos de sequenciamento de genoma (next generation sequencing) como Illumina e PacBio tem fornecido novas ferramentas para análises genéticas/moleculares em larga escala, além de permitirem uma considerável redução de custos (Faure \& Joly, 2015).

\subsection{RAPD}

O sistema de marcadores RAPD (randomly amplified polymorphic DNA) ainda é amplamente utilizado na caracterização de microrganismos, em especial de bactérias (Wei et al., 2014; Pal, 2015). Esse sistema de marcadores se baseia na amplificação de regiões que ocorrem no DNA genômico utilizando primers curtos (10 nt) de sequência arbitrária (Williams et al., 1990). Somente um primer é utilizado para anelar em sítios que flanqueiam regiões alvo (com distância máxima entre os sítios de anelamento de até 4000 nt) ao longo de todo o genoma (Lacerda et al., 2002). De acordo com Williams et al. (1990) a variação em apenas uma base no sítio de anelamento do primer pode impedir a amplificação do fragmento. Os produtos da amplificação via PCR são separados em gel de agarose ou poliacrilamida. A diferença no número e no tamanho dos amplicons pode estar associada com a simples existência de deleções e inserções que ocorrem dentro da região homóloga ao primer (Lacerda et al., 2002). O sistema RAPD pode ser associado com outras estratégias como Bulk segregant analysis (BSA) ou combinada com outros tipos de marcadores, visando aumentar o conhecimento sobre a variabilidade genética/molecular um determinado organismo.

\subsection{BULK SEGREGANT ANALYSIS (BSA)}

BSA é uma estratégia geral de análise genética que permite a busca por polimorfismos associados com características qualitativas ou quantitativas (El-Soda et al., 2014; Zou et al., 2016). Essa técnica é sugerida visando reduzir custos e aumentar a eficiência processo de identificação de polimorfismos entre amostras contrastantes (Quarrie et al., 1999; Sun et al., 2010). A técnica BSA proposta por Michelmore et al. (1991) se baseia no agrupamento do DNA 
de genótipos que compartilham fenótipos comuns em pools ou bulks (com os DNAs componentes calibrados com mesma concentração) para serem contrastados com bulks contrastantes pelo uso de diferentes sistemas de marcadores tais como o RAPD. Sun et al. (2010) citam que o uso de bulks com grandes populações auxilia na identificação de genes, pois ao invés de validar marcadores putativos genotipando uma população inteira, os marcadores candidatos identificados nas etapas iniciais de BSA já têm uma probabilidade maior de serem válidos. Na criação dos bulks é recomendado o uso de grupos paralelos e com mesmas características para evitar falsos positivos, então cria-se bulks contrastantes, tendo também duplicatas de mesma característica, porém, com indivíduos distintos (Sun et al., 2010; Ghazvini et al., 2013).

\subsection{SCAR}

A estratégia de marcadores SCAR (sequence characterized amplified region) emprega, como informação inicial para geração de primers específicos, a sequencia de diversos marcadores usados para fingerprinting (Holmberg et al., 2009), tais como RAPD (Moon et al., 2016) e BOX-PCR (Rossi et al., 2014). Amplicons são purificados e sequenciados, suas sequencias são então usadas para desenho de primers específicos. Uma das vantagens dos marcadores SCAR é que eles podem ser desenvolvidos para qualquer organismo de interesse até mesmo quando a informação genética não esteja disponível (Felici et al., 2008).

\section{ANTIBIÓTICOS E MEIOS SEMI-SELETIVOS}

Historicamente os patógenos procariotos têm sido isolados, detectados e caracterizados principalmente pela técnica de meios semi-seletivos (Priou et al., 2006). O meio Kelman foi um dos primeiros descritos para o CER, constituído do meio CPG (caseína, peptona, glicerol) com a suplementação de cloreto de trifenil tetrazólio (Kelman, 1954). O cultivo de isolados do CER no meio Kelman promove uma coloração diferenciada das colônias, o que permite uma pronta seleção de variantes dessa bactéria. Outros meios diferenciais foram desenvolvidos 
visando solucionar o problema de isolamento seletivo de componentes do CER de solo (Engelbrecht, 1994). A adição de antibióticos promove uma supressão do desenvolvimento de outros organismos "contaminantes", permitindo um número restrito de espécies crescer no meio. Esses meios foram desenvolvidos levando em consideração apenas diversidade local/regional ou usando um número pequeno e pouco representativo de isolados do CER. Dessa forma, quando o meio é avaliado com outros conjuntos de isolados, pode ocorrer a supressão dos mesmos, tornando o meio ineficaz para uma detecção "universal" de subgrupos do patógeno. Essa baixa cobertura da diversidade do CER demanda uma adequação dos meios para outros isolados. Testes de antibiograma visando avaliar novos antibióticos ou estimar os limites de concentração de antibióticos para novos meios de cultura ainda são escassos (Tabela 3). 
Tabela 3. Lista de meios de cultura semi-seletivos, ano de desenvolvimento, seus respectivos componentes e antibióticos empregados.

\begin{tabular}{|c|c|c|c|}
\hline Meio & Ano & Composição & Referencia \\
\hline SM-1 & 1983 & $\begin{array}{l}\text { Cristal violeta } \\
\text { Thimerosal } \\
\text { Polimixina B } \\
\text { Tyrothricin } \\
\text { Clhoromycetin } \\
\text { Ciclohexamida }\end{array}$ & $\begin{array}{l}\text { Rica, Costa. Plant Disease } 67.10 \\
\text { (1983): 1084-1088. }\end{array}$ \\
\hline SMSA-M & 1996 & $\begin{array}{l}\text { Bacitracina } \\
\text { Polimixina B } \\
\text { Cloranfenicol } \\
\text { Penicilina } \\
\text { Cristal violeta } \\
\text { Cloreto de trifenil tetrazólio }\end{array}$ & $\begin{array}{l}\text { Elphinstone JG, Hennessy J, Wilson } \\
\text { JK, Stead DE, 1996. Sensitivity of } \\
\text { different methods for the detection } \\
\text { of Pseudomonas solanacearum } \\
\text { (Smith) in potato tuber extracts. } \\
\text { EPPO Bulletin 26, 663-78. }\end{array}$ \\
\hline CIPEB & 2006 & $\begin{array}{l}\text { Polimixina B } \\
\text { Bacitracina } \\
\text { Penicilina } \\
\text { Cloranfenicol } \\
\text { Ciclohexamida } \\
\text { Cristal violeta } \\
\text { Cloreto de trifenil tetrazólio } \\
\text { Vitamina C }\end{array}$ & $\begin{array}{l}\text { Priou, S., L. Gutarra, and P. Aley. } \\
\text { "An improved enrichment broth for } \\
\text { the sensitive detection of Ralstonia } \\
\text { solanacearum (biovars } 1 \text { and } 2 \text { A) in } \\
\text { soil using DAS-ELISA." Plant } \\
\text { Pathology } 55.1 \text { (2006): 36-45. }\end{array}$ \\
\hline SMSA-P & 2010 & $\begin{array}{l}\text { Piruvato } \\
\text { Bacitracina } \\
\text { Polimixina B } \\
\text { Cloranfenicol } \\
\text { Penicilina } \\
\text { Cristal violeta } \\
\text { Cloreto de trifenil tetrazólio }\end{array}$ & $\begin{array}{l}\text { Imazaki, Iori, and Kazuhiro } \\
\text { Nakaho. "Pyruvate-amended } \\
\text { modified SMSA medium: improved } \\
\text { sensitivity for detection of } \\
\text { Ralstonia solanacearum." Journal } \\
\text { of general plant pathology } 76.1 \\
\text { (2010): } 52-61 \text {. }\end{array}$ \\
\hline
\end{tabular}

\section{OBJETIVOS}

\subsection{OBJETIVO GERAL}

- Ampliar os conhecimentos sobre o complexo de espécies de Ralstonia por meio de estudos de plantas hospedeiras, novas fontes de resistência em tomateiro, fatores e perfil de virulência e desenvolver um novo e mais simplificado protocolo para identificação de biovares. 


\subsection{OBJETIVOS ESPECÍFICOS}

- Caracterizar os potenciais mecanismos de virulência de um isolado atípico de $R$. solanacearum (denominado de CNPH-RS 488), que se mostrou capaz de superar a resistência da linhagem de tomateiro 'Hawaii 7996';

- Desenvolver protocolo molecular para identificação de biovares usando primers específicos para cada uma das quatro biovares presentes no Brasil (1, 2A, 2T \& 3);

- Buscar acessos de S. peruvianum com potencial uso no melhoramento genético do tomateiro visando resistência a murcha bacteriana;

- Caracterizar a espécie Coffea arabica como uma potencial hospedeira experimental do complexo de espécies de Ralstonia.

\section{REFERÊNCIAS BIBLIOGRÁFICAS}

BOGINO, P.C.; OLIVA, M.D.L.M.; SORROCHE, F.G. \& GIORDANO, W. 2013. The role of bacterial biofilms and surface components in plant-bacterial associations. International Journal of Molecular Sciences 14:15838-15859.

BUDDENHAGEN, I.W.; SEQUEIRA, L. \& KELMAN, A. 1962. Designation of races of Pseudomonas solanacearum. Phytopathology 52:726-730.

CARMEILLE, A.; CARANTA, C.; DINTINGER, J.; PRIOR, P.; LUISETTI, J. \& BESSE, P. 2006a. Identification of QTLs for Ralstonia solanacearum race 3-phylotype II resistance in tomato. Theoretical and Applied Genetics 113:110-121.

CARMEILle, A.; PRIOR, P.; KODJA, H.; CHIROLEU, F.; LUISETTI, J. \& BESSE, P. 2006b. Evaluation of resistance to race 3, biovar 2 of Ralstonia solanacearum in tomato germplasm. Journal of Phytopathology 154:398-402.

COOK, D. \& SEQUEIRA, L. Strain differentiation of Pseudomonas solanacearum by molecular genetic methods. Proceedings of the aciar proceedings, 1993: australian centre for international agricultural research, 96-96.

CUNNAC, S.; OCCHIALINI, A.; BARBERIS, P.; BOUCHER, C. \& GENIN, S. 2004. Inventory and functional analysis of the large Hrp regulon in Ralstonia solanacearum: identification of novel effector proteins translocated to plant host cells through the type III secretion system. Molecular Microbiology 53:115-128. 
DANHORN, T. \& FUQUA, C. 2007. Biofilm formation by plant-associated bacteria. Annual Reviews of Microbiology 61:401-422.

DENNY, T.P. 1995. Involvement of bacterial polysaccharides in plant pathogenesis. Annual Review of Phytopathology 33:173-197.

DENNY, T.P. \& HAYWARD, A.C. 2001. Gram-negative bacteria - Ralstonia. In: SCHAAD, N.; JONES, J.B. \& CHUN, W. eds. Laboratory Guide for identification of plant pathogenic bacteria.3 ed.APS Press. Estados Unidos. p. 151-174.

EL-SODA, M.; MALOSETTI, M.; ZWAAN, B.J.; KOORNNEEF, M. \& AARTS, M.G.M. 2014. Genotype $\times$ environment interaction QTL mapping in plants: lessons from Arabidopsis. Trends in Plant Science 19:390-398.

ELPHINSTONE, J.G. 2005. The current bacterial wilt situation: a global overview. In: ALLEN, C.; PRIOR, P. \& HAYWARD, A.C. eds. Bacterial wilt disease and the Ralstonia solanacearum species complex.1 ed.APS Press. Estados Unidos. p. 9-28.

ENGELBRECHT, M.C. 1994. Modification of a semi-selective medium for the isolation and quantification of Pseudomonas solanacearum. Bacterial Wilt Newsletter:3-5.

FAURE, D. \& JOLY, D. 2015. Next-generation sequencing as a powerful motor for advances in the biological and environmental sciences. Genetica 143:129-132.

FEGAN, M. \& PRIOR, P. 2005. How complex is the Ralstonia solanacearum species complex? In: ALLEN, C.; PRIOR, P. \& HAYWARD, A.C. eds. Bacterial wilt disease and the Ralstonia solanacearum species complex.1 ed.APS Press. Estados Unidos. p. 449-461.

FELICI, C.; VETTORI, L.; TOFFANIN, A. \& NUTI, M. 2008. Development of a strainspecific genomic marker for monitoring a Bacillus subtilis biocontrol strain in the rhizosphere of tomato. FEMS microbiology ecology 65:289-298.

FLEMMING, H.-C.; NEU, T.R. \& WOZNIAK, D.J. 2007. The EPS matrix: the "house of biofilm cells". Journal of Bacteriology 189:7945-7947.

GENIN, S. \& BOUCHER, C. 2002. Ralstonia solanacearum: secrets of a major pathogen unveiled by analysis of its genome. Molecular Plant Pathology 3:111-118.

GENIN, S. \& BOUCHER, C. 2004. Lessons learned from the genome analysis of Ralstonia solanacearum. Annual Review of Phytopathology 42:107-134.

GENIN, S. \& DENNY, T.P. 2012. Pathogenomics of the Ralstonia solanacearum species complex. Annual Review of Phytopathology 50:67-89.

GHAZVINI, H.; HIEBERT, C.W.; THOMAS, J.B. \& FETCH, T. 2013. Development of a multiple bulked segregant analysis (MBSA) method used to locate a new stem rust 
resistance gene (Sr54) in the winter wheat cultivar Norin 40. Theoretical and Applied Genetics 126:443-449.

GUIDOT, A.; PRIOR, P.; SCHOENFELD, J.; CARRÈRE, S.; GENIN, S. \& BOUCHER, C. 2007. Genomic structure and phylogeny of the plant pathogen Ralstonia solanacearum inferred from gene distribution analysis. Journal of Bacteriology 189:377-387.

HAI, T.T.H.; ESCH, E. \& WANG, J.-F. 2008. Resistance to Taiwanese race 1 strains of Ralstonia solanacearum in wild tomato germplasm. European Journal of Plant Pathology 122:471-479.

HANSON, P.; LU, S.-F.; WANG, J.-F.; CHEN, W.; KENYON, L.; TAN, C.-W.; TEE, K.L.; WANG, Y.-Y.; HSU, Y.-C. \& SCHAFLEITNER, R. 2016. Conventional and molecular marker-assisted selection and pyramiding of genes for multiple disease resistance in tomato. Scientia Horticulturae 201:346-354.

HAYWARD, A. 1964. Characteristics of Pseudomonas solanacearum. Journal of Applied Bacteriology 27:265-277.

HAYWARD, A.C. 1991a. Biology and Epidemiology of a bacterial wilt caused by Pseudomonas solanacearum. Annual Review of Phytopathology 29:14.

HAYWARD, A.C. 1991b. Biology and epidemiology of bacterial wilt caused by Pseudomonas solanacearum. Annual Review of Phytopathology 29:65-87.

HAYWARD, A.C. 1994. The hosts of Pseudomonas solanacearum. In: HAYWARD, A.C. \& HARTMAN, G.L. eds. Pseudomonas solanacearum: The disease and its causative agent.1 ed.CABI International. Reino Unido. p. 101-115.

HIDA, A.; OKU, S.; KAWASAKI, T.; NAKASHIMADA, Y.; TAJIMA, T. \& KATO, J. 2015. Identification of the mcpA and mcpM genes, encoding methyl-accepting proteins involved in amino acid and i-malate chemotaxis, and involvement of mcpm-mediated chemotaxis in plant infection by Ralstonia pseudosolanacearum (formerly Ralstonia solanacearum phylotypes I and III). Applied and Environmental Microbiology 81:74207430.

HOLMBERG, A.-I.J.; MELIN, P.; LEVENFORS, J.P. \& SUNDH, I. 2009. Development and evaluation of SCAR markers for a Pseudomonas brassicacearum strain used in biological control of snow mould. Biological Control 48:181-187.

HORITA, M.; TSUCHIYA, K. \& OOSHIRO, A. 2005. Characteristics of Ralstonia solanacearum biovar N2 strains in Asia. Journal of Phytopathology 153:209-213.

HUANG, J. \& SCHELL, M. 1995. Molecular characterization of the eps gene cluster of Pseudomonas solanacearum and its transcriptional regulation at a single promoter. Molecular microbiology 16:977-989. 
HUANG, Q. \& ALLEN, C. 2000. Polygalacturonases are required for rapid colonization and full virulence of Ralstonia solanacearum on tomato plants. Physiological and Molecular Plant Pathology 57:77-83.

IVEY, M.L.L.; GARDENER, B.B.M.; OPINA, N. \& MILLER, S.A. 2007. Diversity of Ralstonia solanacearum infecting eggplant in the Philippines. Phytopathology 97:14671475 .

JAWORSKI, C.A.; PHATAK, S.C.; GHATE, S.R.; GITAITIS, R.D. \& WIDRLECHNER, M.P. 1987. Ga 1565-2-4 Bwt, Ga 219-1-2 Bwt, Ga 1095-1-4 Bwt, And Ga 1405-1-2 Bwt bacterial wilt-tolerant tomato. HortScience (USA) 22:324-325.

JEONG, Y.; KIM, J.; KANG, Y.; LEE, S. \& HWANG, I. 2007. Genetic diversity and distribution of Korean isolates of Ralstonia solanacearum. Plant Disease 91:1277-1287.

JIANWEI, L.; HUIFANG, J.; XIAOPING, R.; XIAOJIE, Z. \& BOSHOU, L. 2010. Identification and molecular traits of ICRISAT mini core collection of peanut species with resistance to bacterial wilt. Chinese Agriculture Science Bulletin 26:47-51.

KANG, Y.; LIU, H.; GENIN, S.; SCHELL, M.A. \& DENNY, T.P. 2002. Ralstonia solanacearum requires type 4 pili to adhere to multiple surfaces and for natural transformation and virulence. Molecular Microbiology 46:427-437.

KELMAN, A. 1954. The relationship of pathogenicity in Pseudomonas solanacearum to colony appearance on a tetrazolium medium. Phytopathology 44:693-695.

LACERDA, D.R.; ACEDO, M.D.P.; LEMOS FILHO, J.P.D. \& LOVATO, M.B. 2002. A técnica de RAPD: uma ferramenta molecular em estudos de conservação de plantas. Lundiana 3:87-92.

LEBEAU, A.; DAUNAY, M.C.; FRARY, A.; PALLOIX, A.; WANG, J.F.; DINTINGER, J.; CHIROLEU, F.; WICKER, E. \& PRIOR, P. 2011. Bacterial wilt resistance in tomato, pepper, and eggplant: genetic resources respond to diverse strains in the Ralstonia solanacearum species complex. Phytopathology 101:154-165.

LIN, C.; MUELlER, L.A.; MC CARTHY, J.; CROUZILlAT, D.; PETIARD, V. \& TANKSLEY, S.D. 2005. Coffee and tomato share common gene repertoires as revealed by deep sequencing of seed and cherry transcripts. Theoretical and Applied Genetics 112:114-130.

LIN, C.-H.; HSU, S.-T.; TZENG, K.-C. \& WANG, J.-F. 2009. Detection of race 1 strains of Ralstonia solanacearum in field samples in Taiwan using a BIO-PCR method. European Journal of Plant Pathology 124:75-85.

LOPES, C.A. 2005. Murchadeira da batata. 1 Ed. Associação Brasileira da Batata. Itapetininga. 
LOPES, C.A. 2015. Bacterial Wilt - a disease threatening disease of tomato cultivated under warm temperatures. Comunicado Técnico 109:4.

LOPES, C.A.; BOITEUX, L.S. \& ESCHEMBACK, V. 2015. Eficácia relativa de portaenxertos comerciais de tomateiro no controle da murcha-bacteriana. Horticultura Brasileira 33:125-130.

LOPES, C.A.; ROSSATO, M. \& BOITEUX, L.A. 2009. Murcha-bacteriana: nova ameaça à cafeicultura brasileira. In. Simpósio de Pesquisa dos Cafés do Brasil. Vitória: Embrapa Café.

MALAVOLTA, J.; BERIAM, L.; ALMEIDA, I.; RODRIGUES NETO, J. \& ROBBS, C. 2008. Bactérias fitopatogênicas assinaladas no Brasil: uma atualização. Summa Phytopathologica 34:9-87.

MICHELMORE, R.W.; PARAN, I. \& KESSELI, R.V. 1991. Identification of markers linked to disease-resistance genes by bulked segregant analysis: A rapid method to detect markers in specific genomic regions by using segregating populations. Proceedings of the National Academy of Sciences USA 88:9828-9832.

MILLING, A.; BABUJEE, L. \& ALLEN, C. 2011. Ralstonia solanacearum extracellular polysaccharide is a specific elicitor of defense responses in wilt-resistant tomato plants. PloS One 6:e15853.

MOON, B.C.; LEE, Y.M.; KIM, W.J.; JI, Y.; KANG, Y.M. \& CHOI, G. 2016. Development of molecular markers for authentication of the medicinal plant species Patrinia by random amplified polymorphic DNA (RAPD) analysis and multiplex-PCR. Horticulture, Environment, and Biotechnology 57:182-190.

MURTHY, K.N. \& SRINIVAS, C. 2015. Extraction and characterization of extracellular polysaccharide from Ralstonia solanacearum causing wilt of tomato. International Journal of Agricultural Science and Research (IJASR) 5:81-92.

PAL, P. 2015. RAPD-PCR as a molecular discriminative technique for human pathogenic bacteria-A Review. International Letters of Natural Sciences 42:13-17.

PEETERS, N.; CARRÈRE, S.; ANISIMOVA, M.; PLENER, L.; CAZALÉ, A.-C. \& GENIN, S. 2013. Repertoire, unified nomenclature and evolution of the Type III effector gene set in the Ralstonia solanacearum species complex. BMC Genomics 14:859-877.

PRIOR, P.; AILLOUD, F.; DALSING, B.L.; REMENANT, B.; SANCHEZ, B. \& ALLEN, C. 2016. Genomic and proteomic evidence supporting the division of the plant pathogen Ralstonia solanacearum into three species. BMC Genomics 17:90-101.

PRIOR, P. \& FEGAN, M. Recent developments in the phylogeny and classification of Ralstonia solanacearum. Proceedings of the I International Symposium on Tomato Diseases 695, 2004, 127-136. 
PRIOU, S.; GUTARRA, L. \& ALEY, P. 2006. An improved enrichment broth for the sensitive detection of Ralstonia solanacearum (biovars 1 and 2A) in soil using DAS-ELISA. Plant Pathology 55:36-45.

QUARRIE, S.A.; LAZIĆ-JANČIĆ, V.; KOVAČEVIĆ, D.; STEED, A. \& PEKIĆ, S. 1999. Bulk segregant analysis with molecular markers and its use for improving drought resistance in maize. Journal of Experimental Botany 50:1299-1306.

REMENANT, B.; DE CAMBIAIRE, J.-C.; CELLIER, G.; JACOBS, J.M.; MANGENOT, S.; BARBE, V.; LAJUS, A.; VALLENET, D.; MEDIGUE, C. \& FEGAN, M. 2011. Ralstonia syzygii, the blood disease bacterium and some Asian $R$. solanacearum strains form a single genomic species despite divergent lifestyles. PloS One 6:e24356-e24356.

RICK, C.M. \& CHETELAT, R.T. Utilization of related wild species for tomato improvement. Proceedings of the I International Symposium on Solanacea for Fresh Market 412, 1995, 21-38.

ROSSI, C.C.; PEREIRA, M.F.; LANGFORD, P.R. \& BAZZOLLI, D.M.S. 2014. A BOXSCAR fragment for the identification of Actinobacillus pleuropneumoniae. FEMS Microbiology Letters 352:32-37.

SAFNI, I.; CLEENWERCK, I.; DE VOS, P.; FEGAN, M.; SLY, L. \& KAPPLER, U. 2014. Polyphasic taxonomic revision of the Ralstonia solanacearum species complex: proposal to emend the descriptions of Ralstonia solanacearum and Ralstonia syzygii and reclassify current $R$. syzygii strains as Ralstonia syzygii subsp. syzygii subsp. nov., $R$. solanacearum phylotype IV strains as Ralstonia syzygii subsp. indonesiensis subsp. nov., banana blood disease bacterium strains as Ralstonia syzygii subsp. celebesensis subsp. nov. and $R$. solanacearum phylotype I and III strains as Ralstonia pseudosolanacearum sp. nov. International Journal of Systematic and Evolutionary Microbiology 64:3087-3103.

SAILE, E.; MCGARVEY, J.A.; SCHELL, M.A. \& DENNY, T.P. 1997. Role of extracellular polysaccharide and endoglucanase in root invasion and colonization of tomato plants by Ralstonia solanacearum. Phytopathology 87:1264-1271.

SALANOUBAT, M.; GENIN, S.; ARTIGUENAVE, F.; GOUZY, J.; MANGENOT, S.; ARLAT, M.; BILlAULT, A.; BROTTIER, P.; CAMUS, J. \& CATTOLICO, L. 2002. Genome sequence of the plant pathogen Ralstonia solanacearum. Nature 415:497-502.

SANTIAGO, T.R.; LOPES, C.A.; CAETANO- ANOLLÉS, G. \& MIZUBUTI, E.S.G. 2016. Phylotype and sequevar variability of Ralstonia solanacearum in Brazil, an ancient center of diversity of the pathogen. Plant Pathology.

SMITH, E.F. 1886. A bacterial disease of tomato, eggplant and Irish potato (Bacillus solanacearum sp nov.). Department of Agriculture Division of Vegetable Physiology and Pathology Bulletin 12:7. 
STRANGE, R.N. \& SCOTT, P.R. 2005. Plant disease: a threat to global food security. Phytopathology 43:83-116.

STULBERG, M.J. \& HUANG, Q. 2016. A computer program for fast and easy typing of a partial endoglucanase gene sequence into genospecies and sequevars $1 \& 2$ of the Ralstonia solanacearum species complex. Journal of Microbiological Methods 123:101107.

SUN, Y.; WANG, J.; CROUCH, J.H. \& XU, Y. 2010. Efficiency of selective genotyping for genetic analysis of complex traits and potential applications in crop improvement. Molecular Breeding 26:493-511.

TAKATSU, A. \& LOPES, C.A. 1997. Murcha bacteriana em hortaliças: avanços científicos e perspectivas de controle. Horticultura Brasileira 15:170-177.

TANS-KERSTEN, J.; HUANG, H. \& ALLEN, C. 2001. Ralstonia solanacearum needs motility for invasive virulence on tomato. Journal of Bacteriology 183:3597-3605.

VON PARSEVAL, M. 1922. Uma doença do fumo e da batata inglesa no município de Santa Cruz. Boletim do Instituto Borges de Medeiros 1:15.

WANG, J.-F.; HO, F.-I.; TRUONG, H.T.H.; HUANG, S.-M.; BALATERO, C.H.; DITTAPONGPITCH, V. \& HIDAYATI, N. 2013. Identification of major QTLs associated with stable resistance of tomato cultivar 'Hawaii 7996'to Ralstonia solanacearum. Euphytica 190:241-252.

WANG, J.F.; HANSON, P. \& BARNES, J.A. 1998. Worldwide evaluation of an international set of resistance sources to bacterial wilt in tomato. In: PRIOR, P.; ALLEN, C. \& ELPHINSTONE, J. eds. Bacterial Wilt Disease.1 ed.Springer. Alemanha. p. 269-275.

WEI, L.S.; MUSA, N.; WEEL, W.; SENG, C.T.; SHAZILI, N.A.M. \& SHAHAROM, F. 2014. Review on RAPD-PCR as a Discriminative Tool for Fish Bacteria. Chinese papers 5:1019.

WICKER, E.; GRASSART, L.; CORANSON-BEAUDU, R.; MIAN, D.; GUILBAUD, C.; FEGAN, M. \& PRIOR, P. 2007. Ralstonia solanacearum strains from Martinique (French West Indies) exhibiting a new pathogenic potential. Applied and Environmental Microbiology 73:6790-6801.

WICKER, E.; LEFEUVRE, P.; DE CAMBIAIRE, J.-C.; LEMAIRE, C.; POUSSIER, S. \& PRIOR, P. 2012. Contrasting recombination patterns and demographic histories of the plant pathogen Ralstonia solanacearum inferred from MLSA. The ISME Journal 6:961974.

WILLIAMS, J.G.K.; KUBELIK, A.R.; LIVAK, K.J.; RAFALSKI, J.A. \& TINGEY, S.V. 1990. DNA polymorphisms amplified by arbitrary primers are useful as genetic markers. Nucleic Acids Research 18:6531-6535. 
WILLIAMSON, L.; NAKAHO, K.; HUDELSON, B. \& ALLEN, C. 2002. Ralstonia solanacearum race 3, biovar 2 strains isolated from geranium are pathogenic on potato. Plant Disease 86:987-991.

YABUUCHI, E.; KOSAKO, Y.; YANO, I.; HOTTA, H. \& NISHIUCHI, Y. 1995. Transfer of two Burkholderia and an Alcaligenes species to Ralstonia gen. nov.: proposal of Ralstonia picketti (Ralston, Palleroni and Douderoff 1973) comb. nov., Ralstonia solanacearum (Smith 1986) comb. nov. \& Ralstonia eutropha (Davis 1969) comb. nov. . Microbiology and Immunology 39:7.

ZHANG, Y. \& QIU, S. 2016. Phylogenomic analysis of the genus Ralstonia based on 686 single-copy genes. Antonie van Leeuwenhoek 109:71-82.

ZHAO, Y.; ZHANG, C.; CHEN, H.; YUAN, M.; NIPPER, R.; PRAKASH, C.S.; ZHUANG, W. \& HE, G. 2016. QTL mapping for bacterial wilt resistance in peanut (Arachis hypogaea L.). Molecular Breeding 36:1-11.

ZOU, C.; WANG, P. \& XU, Y. 2016. Bulked sample analysis in genetics, genomics and crop improvement. Plant Biotechnology Journal 14:1941-1955. 


\section{CAPÍTULO 1}

CARACTERIZAÇÃO DE UM ISOLADO DE Ralstonia solanacearum CAPAZ DE SUPERAR A RESISTÊNCIA DA LINHAGEM DE TOMATEIRO (Solanum lycopersicum) 'HAWAII 7996' 


\section{Caracterização de um isolado de Ralstonia solanacearum capaz de superar a resistência da linhagem de tomateiro (Solanum lycopersicum) 'Hawaii 7996'}

\section{RESUMO}

O complexo de espécies de Ralstonia (CER) é uma grande ameaça à cultura do tomateiro, podendo causar grandes perdas. O emprego de cultivares com resistência genética é um dos principais métodos de controle da doença no tomateiro, porém a principal fonte de resistência (a linhagem Solanum lycopersicum 'Hawaii 7996') teve sua resistência quebrada por um isolado (denominado CNPH-RS 488) no Estado do Paraná em 2012. O presente capítulo apresentou como objetivo a caracterização e elucidação dos potenciais mecanismos de virulência desse isolado. O isolado CNPH-RS 488 foi identificado como pertencente à raça 3, biovar 2A, filotipo II, sequevar 1. Em testes de patogenicidade, o isolado CNPH-RS 488 foi o único dentre os isolados da biovar 2A capaz de causar murcha em todas as plantas de 'Hawaii 7996'. Na titulação da pressão de inóculo (infectividade) a concentração de $10^{8} \mathrm{ufc} / \mathrm{mL}$ se destacou, permitindo uma elevada incidência de plantas sintomáticas nas linhagens 'Hawaii 7996' e 'L390' com todos os isolados empregados. Foi também verificado que nas duas maiores concentrações o isolado CNPH-RS 488 causou murcha das plantas mais rapidamente um maior número de plantas ‘Hawaii 7996' que os demais isolados. A quantidade de exopolissacarídeo produzido pelos isolados não se mostrou alta e diretamente correlacionada com maior ou menor virulência em tomateiro. Similar tendência foi observada em relação à produção de biofilme, com o CNPH-RS 488 fazendo parte, para essa característica, do mesmo grupo de isolados de baixa e média virulência. Apenas os isolados pertencentes à biovar 3 foram capazes de crescer no meio semi-seletivo SMART, não sendo observado o desenvolvimento de isolados das biovares 1, 2A e 2T. Desta forma, esse meio não é recomendado seu uso para isolados brasileiros do CER. O antibiograma com um painel de 16 diferentes antibióticos indica a possibilidade do desenvolvimento de um meio usando oxacilina e clindamicina, associados a 
outros antibióticos para o isolamento seletivo de patógenos pertencentes ao CER. No estudo de gama de hospedeiras com as espécies amendoim (Arachis hypogaea), tagetes (Tagetes patula), jiló (Solanum aethiopicum var. gilo), berinjela (S. melongena) e gergelim (Sesamun indicum), foi possível verificar que o isolado CNPH-RS 488 é capaz de causar doença em jiló e berinjela, hospedeiras consideradas de maior resistência a biovar 2A.

Palavras-chave: biofilme, exopolissacarídeo, hospedeiros. 


\title{
Characterization of a Ralstonia solanacearum isolate capable of breaking down the resistance of the tomato (Solanum lycopersicum) line 'Hawaii 7996'
}

\begin{abstract}
The Ralstonia species complex is a great threat for the tomato crop, which may cause potential economic and quality losses. The deployment of cultivars with genetic resistance is one of the main methods of control available. However, the resistance of the inbred line 'Hawaii 7996' (one of the most employed resistant germplasm sources) was broken down by the $R$. solanacearum CNPH-RS 488 isolate, collected from Paraná State in 2012. The main objectives of the present work were to characterize this isolate and to investigate its putative virulence mechanisms. CNPH-RS 488 was identified as race 3/biovar 2A, phylotype II, and sequevar I. In pathogenicity tests, $R$. solanacearum CNPH-RS 488 was the only isolate of the biovar $2 \mathrm{~A}$ group capable of causing wilt in all 'Hawaii 7996' plants. With the inoculum pressure (infection) tittering, the concentration of $10^{8} \mathrm{cfu} / \mathrm{mL}$ was found to be the most efficient on inducing wilt symptoms. This concentration allowed all the isolates to induce higher levels of incidence on both standard tomato lines. It was verified that the isolate CNPH-RS 488 on the two highest concentrations could wilt a higher number of 'Hawaii 7996' and it also induced faster symptom onset than other isolates. The amount of exopolysaccharide produced by the isolates did not strongly correlate with virulence levels on tomato. A similar result was found in relation to biofilm formation. The isolate CNPH-RS 488 did not group with the isolates with high virulence. The semi-selective medium SMART did not allow the development of isolates from the biovars 1, 2A and 2T. Only biovar 3 isolates could develop normally. Therefore, the SMART medium is not recommended for isolation of Brazilian isolates of Ralstonia species complex. The antibiogram with a panel of 16 antibiotics showed the possibility of development of a semi-selective medium for Ralstonia species isolation using oxacilin and clindamicin, associated to other commonly used antibiotics. In the host range studies employing peanut
\end{abstract}


(Arachis hypogaea), marigold (Tagetes patula), scarlet eggplant (Solanum aethiopicum var. gilo), eggplant (S. melongena), and sesame (Sesamun indicum), it was possible to confirm that the isolate CNPH-RS 488 is also capable of infecting scarlet eggplant and eggplant, two hosts with higher resistance levels to biovar $2 \mathrm{~A}$ isolates.

Keywords: biofilm, exopolysaccharide, host range. 


\section{INTRODUÇÃO}

Ralstonia solanacearum (Smith) (Yabuuchi et al., 1995) é uma bactéria gram-negativa habitante do solo com capacidade de infectar uma ampla gama de hospedeiras em mais de 50 famílias botânicas (Kelman, 1954; Hayward, 1991; Hayward, 1994; Plener et al., 2012). Ralstonia solanacearum foi recentemente subdividida em três espécies, podendo ser chamada também de complexo de espécies de Ralstonia (CER). Os isolados de CER estão distribuídos no mundo inteiro onde causam a murcha bacteriana, uma das doenças mais destrutivas do mundo (Genin \& Denny, 2012).

As bactérias do CER iniciam o processo de infecção por meio da penetração na planta hospedeira por ferimentos, aberturas naturais ou pontos de emergência de raízes e se desenvolvem nos espaços intercelulares até alcançar os vasos do xilema (Hayward, 1991; Yao \& Allen, 2007). No tomateiro (Solanum lycopersicum L.), os isolados de CER induzem típicos sintomas de murcha verde, resultante do entupimento do xilema e também da necrose dos vasos. As grandes perdas econômicas causadas por essa doença se devem aos sintomas de murcha irreversível e morte das plantas, que ocorrem especialmente durante o período de frutificação (Lopes, 2005). No Brasil, a murcha bacteriana é considerada um dos principais problemas fitossanitários do cultivo do tomateiro e outras solanáceas em condições de cultivo protegido e é o principal fator limitante para produção de tomate na região amazônica (Lopes, 2015).

Devido a sua enorme diversidade, os patógenos pertencentes ao CER têm sido classificados em cinco raças (Buddenhagen et al., 1962), cinco biovares (Hayward, 1991), quatro filotipos e 57 sequevares (Fegan \& Prior, 2005; Wicker et al., 2012; Santiago et al., 2016). Uma proposta alternativa (definindo patotipos e perfis patogênicos) foi elaborada visando auxiliar no processo de seleção de isolados representativos para uso em programas de melhoramento de tomateiro, pimentas e pimentões (Capsicum spp.) e berinjela (Solanum melongena) (Lebeau et al., 2011). Além disso, foram identificados cinco grandes tipos de 
isolados ecologicamente similares ou ecotipos ("moko", "podridão marrom", "isolados de amora", "isolados que afetam gengibre" e "isolados emergentes"). Esses ecotipos se caracterizam por compartilharem os tipos de sintomas induzidos, as hospedeiras e outras características bioquímicas e ecológicas (Cohan, 2006; Wicker et al., 2012).

Existe também a proposta de divisão do CER em distintas espécies, levando em consideração a variabilidade presente entre os diferentes filotipos. Os isolados do filotipo II foram identificados como pertencentes à espécie $R$. solanacearum. Por sua vez, os isolados dos filotipos I e III foram classificados como pertencentes a uma nova espécie, denominada de $R$. pseudosolanacearum. Os isolados do filotipo IV foram classificados como pertencentes à espécie R. syzygii (Safni et al., 2014). Mais recentemente, Zhang \& Qiu (2016) sugeriram a divisão de $R$. solanacearum e de $R$. pseudosolanacearum em duas subespécies cada uma, buscando uma melhor catalogação da diversidade desses patógenos.

A elucidação dos mecanismos de patogênese é essencial para entender tanto o processo de suplantação quanto de estabilidade da resistência do tomateiro aos isolados pertencentes ao CER. A produção de exopolissacarídeo (EPS) (Murthy \& Srinivas, 2015), a formação de biofilme (Mori et al., 2015) e a variabilidade do sistema secretor do tipo III (SST3) (Valls et al., 2006) são alguns dos mecanismos de patogênese caracterizados nesse complexo bacteriano. Além disso, a caracterização detalhada desses mecanismos pode fornecer informações cruciais, visando elucidar os fatores associados com a vasta gama de plantas hospedeiras desse grupo de patógenos (Genin, 2010), a resistência/suscetibilidade apresentada por alguns acessos e variedades dentro das espécies hospedeiras, bem como os diferentes atributos ecológicos, fisiológicos, bioquímicos e moleculares deste complexo bacteriano.

O EPS, por exemplo, é o mecanismo associado com a proteção da integridade da célula bacteriana, impedindo as ações de defesa da planta, o contato com antibióticos e evitando o 
ressecamento (Murthy \& Srinivas, 2015). Em acessos resistentes de tomateiro (ex. Solanum lycopersicum 'Hawaii 7996') o EPS pode ser identificado/percebido pelos sistemas de defesa da célula hospedeira e funcionar como um MAMP (microbe associated molecular pattern), elicitando a resposta de resistência (Milling et al., 2011).

O biofilme, composto majoritariamente pelo EPS e, em parte, por outros componentes celulares, já foi o foco de diversos estudos. Genes e mecanismos celulares necessários para início da formação do biofilme têm sido investigados, não existindo um enfoque de relação de volume ou velocidade de sua produção com capacidade de alguns isolados de "quebrar" fatores de resistência presentes em plantas hospedeiras (Yao \& Allen, 2007; Wairuri et al., 2012).

Existe pouca informação disponível na literatura sobre resistência aos diferentes grupos de antibióticos por espécies do gênero Ralstonia bem como o uso dessa informação no desenvolvimento de meios semi-seletivos. As primeiras tentativas de elaboração de meios semiseletivos para o gênero Ralstonia foram feitas no início da década de 1980 (Rica, 1983), quando técnicas moleculares apresentavam custo elevado e não estavam ainda sendo amplamente utilizadas. Entre os meios utilizados para detecção de espécies de Ralstonia em amostras

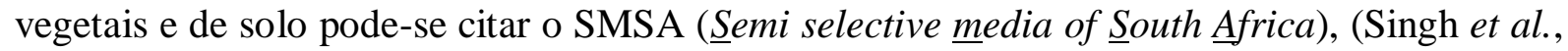
2014; Liu et al., 2016). No entanto, atualmente o emprego dos meios semi-seletivos é limitado aos trabalhos de isolamento e detecção. Os meios semi-seletivos atuais são modificações de outros previamente descritos, alterando a concentração e os grupos de antibióticos (Rica, 1983; Elphinstone et al., 1996; Priou et al., 2006; Imazaki \& Nakaho, 2010). A maior parte desses meios não apresenta utilidade com isolados brasileiros do gênero Ralstonia. Os isolados brasileiros apresentam inibição de crescimento nas concentrações de antibióticos descritas, provavelmente devido à diversidade dos patógenos nos locais onde os referidos meios foram inicialmente desenvolvidos. A ausência de meios semi-seletivos com ampla capacidade de isolamento de espécies de Ralstonia representa um interessante campo de pesquisa no sentido 
de desenvolver novos e eficientes meios para isolar representantes deste grupo de patógenos nas condições brasileiras.

Os patógenos causadores da murcha bacteriana permanecem no solo por longos períodos, sobrevivendo a partir da utilização de matéria orgânica (van Elsas et al., 2000) e, de forma epifítica, na rizosfera das plantas (Wu et al., 2015). Essa característica biológica do CER torna difícil a sua eliminação de áreas infestadas. Outro fator que dificulta o controle de murcha bacteriana é a ampla gama de espécies hospedeiras (Bi-hao et al., 2009). Diversas alternativas de manejo foram implementadas visando o controle da murcha bacteriana no tomateiro, tais como fertilizantes supressivos (Liu et al., 2015), controle biológico (Hyakumachi et al., 2013; Elsharkawy et al., 2015; Yamamoto et al., 2015), óleos essenciais (Sood \& Kumar, 2015), rotação de culturas (Yadessa et al., 2010; Deberdt et al., 2015) e enxertia (Rivard et al., 2012). No entanto, a utilização de cultivares com resistência genética é considerada a estratégia mais eficaz e economicamente viável de controle da murcha bacteriana (Hayward, 1991; Strange \& Scott, 2005; Jianwei et al., 2010; Zhao et al., 2016).

Devido à importância do CER para a cultura do tomateiro, muita informação já foi obtida sobre cultivares resistentes e sobre os mecanismos de resistência à murcha bacteriana. Fontes de resistência para uso no melhoramento genético já foram descritas, incluindo vários acessos de espécies silvestres do gênero Solanum (Kim et al., 2016). No entanto, a linhagem $S$. lycopersicum 'Hawaii 7996' ainda é considerada como uma das melhores fontes de resistência disponíveis, sendo empregada como controle resistente em experimentos de avaliação de resistência a isolados do CER devido a sua estabilidade e ao seu amplo espectro de eficiência (Grimault et al., 1995; Wang et al., 2000; Lebeau et al., 2011). Por essa razão, o acesso 'Hawaii 7996', bem como populações e híbridos derivados desse acesso, se tornaram opções preferenciais para emprego como porta enxerto (Cardoso et al., 2006; Lopes et al., 2015) e também no desenvolvimento de cultivares resistentes (Scott et al., 2004). 
A resistência contra uma ampla gama de isolados do CER identificada no acesso 'Hawaii 7996' é controlada por diversos QTLs (Quantitative Trait Loci) que apresentam distintos efeitos na expressão fenotípica dessa característica (Kim et al., 2016). Os QTLs presentes no cromossomo 6 e no cromossomo 12 têm participação importante na expressão dos níveis e no espectro da resistência (Wang et al., 2000). Por exemplo, no cromossomo 6 residem fatores de resistência de mais amplo espectro, enquanto no cromossomo 12 existem QTLs que englobam fatores de resistência do tipo isolado-específico (Wang et al., 2000). Milling et al. (2011) confirmaram a resistência do acesso 'Hawaii 7996' a isolados de raça 1/biovar 3 (filotipo I). No entanto, foi verificado que um isolado da raça 3/biovar 2 (filotipo II) foi capaz de "quebrar" a resistência do 'Hawaii 7996' (Milling et al., 2011).

O CER é considerado um grupo de patógenos cosmopolita, apresentando uma extensa gama de hospedeiras (Genin \& Denny, 2012). Em trabalhos recentes foram identificadas variantes dentro do CER que apresentaram um aumento da gama de plantas hospedeiras. Originalmente causando murcha em bananeiras, isolados da raça 2, filotipo II, têm variantes que passaram a afetar outras hospedeiras como antúrio, cucurbitáceas e solanáceas, incluindo a importante espécie batateira (Wicker et al., 2007). Frequentemente novas hospedeiras são relatadas no mundo para este importante grupo de patógenos. Na última revisão de hospedeiras de bacterioses no Brasil, foram identificadas 77 espécies relatadas como suscetíveis ao CER (Malavolta et al., 2008).

\subsection{Objetivos}

Nesse contexto, o escopo do presente capítulo foi caracterizar e elucidar os potenciais mecanismos de virulência de um isolado de $R$. solanacearum (denominado de CNPH-RS 488), que se mostrou altamente virulento à linhagem resistente 'Hawaii 7996'. Para tal, foram conduzidos estudos comparativos com outros isolados com mesma biovar. A resposta de um 
conjunto de linhagens de tomateiro, de um clone suscetível de batata e de outras espécies hospedeiras a este isolado foi comparada com outros isolados do CER disponíveis na coleção de bactérias da Embrapa Hortaliças. Investigações sobre potenciais mecanismos de patogênese e também, diferença de antibiograma entre os diversos isolados foram também conduzidos visando uma caracterização fenotípica mais completa desse isolado de $R$. solanacearum.

\section{MATERIAL E MÉTODOS}

De acordo com os objetivos de cada experimento, diferentes combinações de isolados foram usadas. As informações sobre os isolados pertencentes ao CER utilizados nos diferentes bioensaios descritos no presente trabalho estão detalhadas na Tabela 4.. Todos os experimentos foram realizados no Centro Nacional de Pesquisas de Hortaliças (CNPH) nos laboratórios de Fitopatologia e de Genômica ou na casa de vegetação 01. Os isolados brasileiros do gênero Ralstonia da coleção de bactérias da Embrapa Hortaliças que foram utilizados para os experimentos foram mantidos armazenados em tubos de $5 \mathrm{~mL}$ com água mineral em temperatura ambiente. Os isolados exóticos (de origem externa ao Brasil) foram cedidos pela University of Wisconsin.

\subsection{Caracterização do isolado CNPH-RS 488}

\subsubsection{Identificação da biovar}

A caracterização da biovar do isolado CNPH-RS 488 foi conduzida de acordo com os critérios estabelecidos por Hayward (1991) com modificações. Uma placa de cultura de tecidos de 24 poços foi utilizada como suporte nas análises da capacidade do isolado de metabolizar açúcares e alcoóis (Buddenhagen \& Kelman, 1964; Hayward, 1991; Hayward, 1994). Avaliações foram feitas após 14 dias de incubação em câmara de crescimento a $28^{\circ} \mathrm{C}$. 


\subsubsection{Identificação de filotipo}

O filotipo do isolado CNPH-RS 488, foi determinado pelo uso da técnica de PCR Multiplex, que utiliza diferentes primers em conjunto em uma única reação. Foram utilizados os primers Nmult: 21: 1F, Nmult: 21: 2 F, Nmult: 22: inf, Nmult: 23: AF na direção senso, e somente um primer no sentido reverso (antisenso), o Nmult: 22: RR. A identificação/diferenciação de cada filotipo de um isolado foi feita pela análise do perfil de amplicons gerados com esse conjunto de primers da região 16S RNA ribossomal, de acordo com Fegan \& Prior (2005). A reação utilizada foi composta por tampão 1X da Taq DNA polimerase, 0,2 $\mathrm{mM}$ de dNTPs, 1,5 $\mathrm{mM}$ de $\mathrm{MgCl}_{2}, 2 \mathrm{U}$ de Taq polimerase, $0,24 \mu \mathrm{L}$ dos primers Nmult:21: 1F, Nmult:21: 2F, Nmult:22: InF, $0,4 \mu \mathrm{L}$ do primer Nmult22: RR, $0,72 \mu \mathrm{L}$ do primer Nmult: 23: AF. O volume final da reação foi ajustado para $25 \mu \mathrm{L}$ pela adição de água Milli-Q. A PCR seguiu o seguinte protocolo: desnaturação inicial a $96^{\circ} \mathrm{C} / 5$ minutos, $30 \mathrm{X}\left(94^{\circ} \mathrm{C} / 15 \mathrm{~s}\right.$, $59^{\circ} \mathrm{C} / 30 \mathrm{~s}, 72^{\circ} \mathrm{C} / 30 \mathrm{~s}$ ) e extensão final de $72^{\circ} \mathrm{C} / 10$ min. Todos os fragmentos gerados pela reação multiplex foram analisados em gel de agarose a 1,25\% e corados com brometo de etídio.

\subsection{Testes de patogenicidade}

\subsubsection{Teste de patogenicidade em tomateiro e batateira}

Para caracterização patogênica do isolado CNPH-RS 488, foi realizado um teste de patogenicidade na linhagem de tomateiro suscetível ('L390') e na linhagem resistente ('Hawaii 7996') (Wang et al., 2000). Esses ensaios foram conduzidos visando confirmar a capacidade do isolado CNPH-RS 488 de suplantar resistência da linhagem 'Hawaii 7996' em comparação com outros isolados da biovar 2A (CNPH-RS 461, CNPH-RS 498 e CNPH-RS 534) (Tabela 4). Esses três isolados foram selecionados tendo como critério um período transcorrido de isolamento menor ou igual do que três anos em relação ao isolado CNPH-RS 488 (obtido em 2012). Além disso, os isolados incluídos nas análises foram obtidos de batata ou tomate (hospedeiras dentro da família Solanaceae). Os isolados selecionados para essas avaliações 
foram riscados em meio CPG (Kelman, 1954) com modificações, substituindo a sacarose pelo glicerol. As placas foram mantidas em câmara de crescimento por 48 horas a $28^{\circ} \mathrm{C}$. Colônias típicas foram repicadas para outras placas e mantidas pelo mesmo período em câmara de crescimento.

Mudas das linhagens de tomateiro ('L390' e 'Hawaii 7996') foram produzidas em casa de vegetação após semeio em bandejas de isopor preenchidas com substrato esterilizado. As mudas com aproximadamente quatro folhas verdadeiras $(\approx 25$ dias após semeio $)$ foram transplantadas para vasos de 0,5 L. Para a batata, tubérculos brotados da cultivar suscetível 'Monalisa' foram plantados em vasos com substrato. Após o surgimento de brotos acima da superfície do solo, as plantas foram consideradas prontas para a inoculação. A inoculação foi realizada pela penetração do caule, $3 \mathrm{~cm}$ acima do nível do solo, utilizando um alfinete de costura $\mathrm{N}^{\circ} 7$ previamente inserido em uma colônia de cada isolado (Hong et al., 2008). $\mathrm{O}$ delineamento foi inteiramente casualizado com duas plantas por vaso, com um total de oito plantas de cada linhagem para cada isolado. As plantas inoculadas foram mantidas em casa de vegetação, com sistema de aquecimento noturno, sob uma temperatura entre 20 e $40^{\circ} \mathrm{C}$. Essas temperaturas controladas foram aplicadas visando minimizar a frequência de possíveis escapes das plantas à infecção pelos isolados do patógeno. A incidência da doença foi avaliada diariamente assim que a primeira planta apresentou sintomas de murcha. As avaliações foram encerradas aos 15 dias após a primeira avaliação. A reação foi considerada positiva quando mais de $50 \%$ das folhas de cada planta apresentavam sintomas de murcha.

\subsection{Correlação UFC/mL e absorbância e titulação de infectividade}

Visando verificar uma potencial correlação entre o valor de absorbância em espectrofotômetro e as unidades de formação de colônia (UFC/mL), os isolados de $R$. solanacearum previamente selecionados (CNPH-RS 461, CNPH-RS 488, CNPH-RS 498 e 
CNPH-RS 534) (Tabela 4) foram riscados, repicados e as colônias foram raspadas após adição de água destilada para alcançar 0.2 de absorbância no espectrofotômetro, no comprimento de onda de $550 \mathrm{~nm}$ (Yamada et al., 2007). Em seguida foi realizada uma diluição seriada (seis vezes) das suspensões. Alíquotas de $100 \mu \mathrm{L}$ das três menores concentrações foram riscadas em placas contendo meio Kelman, com três repetições para cada isolado. As placas foram incubadas em câmara de crescimento por 48 horas a $28^{\circ} \mathrm{C}$. Cada placa foi subdividida em quatro regiões e as colônias contadas para obter uma estimativa de média e um cálculo aproximado do número de UFC/mL da suspensão original.

Tabela 4. Lista de isolados do complexo de espécies de Ralstonia usados nos experimentos com suas respectivas hospedeiras, local de coleta, data do isolamento, biovar e filotipo. Isolados com origem no Brasil foram identificados com o Estado/País de origem, isolados estrangeiros foram identificados com o país de origem.

\begin{tabular}{lllccc}
\multicolumn{1}{c}{ Isolado } & Hospedeira & \multicolumn{1}{c}{ Local } & Data & Biovar & Filotipo \\
CNPH-RS 077 & Berinjela & Distrito Federal & 1991 & $2 \mathrm{~T}$ & II \\
CNPH-RS 403 & Tomate & Acre & 2010 & 3 & I \\
CNPH-RS 429 & Batata & Minas Gerais & 2010 & $2 \mathrm{~A}$ & II \\
CNPH-RS 443 & Tomate & Distrito Federal & 2011 & 1 & II \\
CNPH-RS 460 & Tomate & Paraná & 2011 & 1 & I \\
CNPH-RS 461 & Batata & Bahia & 2011 & $2 \mathrm{~A}$ & II \\
CNPH-RS 482 & Eucalipto & Goiás & 2012 & $2 \mathrm{~T}$ & II \\
CNPH-RS 488 & Tomate & Paraná & 2012 & $2 \mathrm{~A}$ & II \\
CNPH-RS 489 & Tomate & Paraná & 2012 & 1 & II \\
CNPH-RS 501 & Tomate & Ceará & 2012 & 1 & II \\
CNPH-RS 506 & Berinjela & Ceará & 2012 & $2 \mathrm{~A}$ & II \\
CNPH-RS 507 & Berinjela & Ceará & 2012 & 3 & I \\
CNPH-RS 510 & Tomate & Bahia & 2013 & 3 & I \\
CNPH-RS 534 & Batata & Goiás & 2013 & $2 \mathrm{~A}$ & II \\
CNPH-RS 537 & Batata & São Paulo & 2013 & $2 \mathrm{~A}$ & II \\
CNPH-RS 541 & Pimenta & Distrito Federal & 2013 & 3 & I \\
CNPH-RS 546 & Batata & Minas Gerais & 2014 & $2 \mathrm{~T}$ & II \\
GMI1000 & Tomate & Guiana Francesa & 1978 & 1 & I \\
K60 & Tomate & EUA, NC & 1954 & 1 & II \\
UW151 & Gengibre & Austrália & 1967 & 4 & I \\
UW363 & Tomate & China & 1980 & 3 & I \\
UW386 & Tomate & Nigéria & 1983 & 1 & III \\
\hline
\end{tabular}


Para o ensaio de titulação de infectividade (padronização da pressão de inóculo) foram empregadas plantas de tomateiro das linhagens 'Hawaii 7996' e 'L390', multiplicadas em bandejas de isopor de 128 células com substrato esterilizado, até o estágio de quatro folhas verdadeiras. Os isolados para a inoculação foram selecionados baseando-se nos experimentos anteriores, sendo eles: CNPH-RS 461, CNPH-RS 488, CNPH-RS 498 e CNPH-RS 534 (Tabela 4). Os isolados foram cultivados em meio CPG sem tetrazólio e mantidos em câmara de crescimento por 48 horas a $28^{\circ} \mathrm{C}$. Colônias típicas foram selecionadas, repicadas para outras placas e mantidas pelo mesmo tempo em câmara de crescimento. O inóculo foi obtido pela raspagem das colônias do meio com concentração de $10^{8} \mathrm{UFC} / \mathrm{mL}$, ajustada em espectrofotômetro. Diluições seriadas foram obtidas e ajustadas para as concentrações de $10^{7}$, $10^{6}, 10^{5}, 10^{4} \mathrm{UFC} / \mathrm{mL}$. Para a inoculação, 18 plantas de cada linhagem tiveram seu sistema radicular (ainda aderido ao substrato da bandeja) pulverizado com um borrifador, distribuindo $1 \mathrm{~mL}$ por cada uma das quatro faces do torrão, atingindo o volume de $4 \mathrm{~mL}$ por planta (Lopes et al., 2015). Após a inoculação, as plantas foram transplantadas para vasos de $1 \mathrm{~L}$ e mantidas em casa de vegetação com aquecimento noturno e temperatura ambiente entre 20 e $40^{\circ} \mathrm{C}$. O delineamento experimental foi inteiramente casualizado com uma planta por vaso e 18 por linhagem por isolado. As avaliações se iniciaram três dias após a inoculação, prolongando-se por 16 dias após a inoculação.

\subsection{Quantificação de Exopolissacarídeo (EPS).}

Para a quantificação da produção de EPS dos isolados biovar 2A, CNPH-RS 429, CNPHRS 461, CNPH-RS 498, CNPH-RS 506, CNPH-RS 534, e do isolado CNPH-RS 488 (Tabela 4) foi seguido o protocolo de Brumbley \& Denny (1990). Foram incluídos os isolados de referência K60 (biovar 1), GMI1000 (biovar 3), CNPH-RS 541 (biovar 3) e também isolados de outras biovares $(1,2 \mathrm{~A}$ e $2 \mathrm{~T})$. Os isolados foram riscados em meio CPG e incubados em câmara de crescimento por 48 horas a $28^{\circ} \mathrm{C}$. Colônias típicas foram repicadas para tubos 
Falcon ${ }^{\circledR}$ de $50 \mathrm{~mL}$ esterilizados, contendo $10 \mathrm{~mL}$ de meio BG (1\% peptona bacteriológica, $0.1 \%$ caseína hidrolisada, $0,1 \%$ extrato de levedura, $0,5 \%$ glicerol) e postas para crescer em mesa agitadora orbital por 48 horas a $28^{\circ} \mathrm{C}$ e $210 \mathrm{rpm}$. As suspensões foram centrifugadas a 10.000 g por 10 minutos a $4^{\circ} \mathrm{C}$ e o sobrenadante removido para outro tubo onde foram adicionados quatro volumes de acetona para precipitação (overnight a $4^{\circ} \mathrm{C}$ ). Após a precipitação, os tubos foram centrifugados a $13.000 \mathrm{X}$ g por 10 minutos a $4^{\circ} \mathrm{C}$ e o sobrenadante foi removido. Foram adicionados $500 \mu \mathrm{L}$ de água Milli-Q e os tubos colocados em banho-maria a $65^{\circ} \mathrm{C}$ por 10 minutos, para solubilização completa do pellet. Somente $10 \mu \mathrm{L}$ da solução foram utilizados no teste.

Para a quantificação do EPS, foi feita uma curva de calibração com sacarose. Para isso, uma solução na concentração de $10 \mathrm{mg} / \mathrm{mL}$ foi feita e por meio de diluição seriada, foram produzidas soluções de $0,5 \mathrm{~mL}$ com 10, 20, 40, 60, 80, 100 e $200 \mu \mathrm{g} \cdot \mathrm{mg}^{-1}$ cada. Após o preparo dos padrões, foi adotado o procedimento de Dubois et al. (1956), adicionando $500 \mu \mathrm{L}$ de solução de fenol 5\% (agitado levemente). Em seguida foram adicionados 2,5 $\mathrm{mL}$ de $\mathrm{H}_{2} \mathrm{SO}_{4}$ concentrado, diretamente sobre a amostra e brevemente homogeneizando. As amostras permaneceram por 20 minutos em temperatura ambiente para resfriamento. As leituras foram realizadas em cubetas de vidro em um espectrofotômetro no comprimento de onda de $485 \mathrm{~nm}$ (Murthy \& Srinivas, 2015). Para a quantificação do EPS produzido pelos isolados, a mesma metodologia descrita para a curva de calibração foi aplicada. Para o experimento, os nove isolados utilizados foram analisados com três repetições por isolado. Os gráficos foram gerados e os resultados analisados pelo teste de Scott-Knott ao nível de significância de 5\% no programa SISVAR (Ferreira, 2011). 


\subsection{Produção de biofilme}

Devido ao papel relevante do biofilme na patogênese de bactérias do CER, estudos foram conduzidos visando determinar correlação entre uma eventual produção diferenciada de biofilme do isolado CNPH-RS 488 em comparação com outros isolados não virulentos na linhagem 'Hawaii 7996' tais como subgrupos pertencentes à biovar 1 (CNPH-RS 443, CNPHRS 460, CNPH-RS501); à biovar 2A (CNPH-RS 429, CNPH-RS 461, CNPH-RS 498, CNPHRS 506, CNPH-RS 534, CNPH-RS 537); à biovar 2T (CNPH-RS 77, CNPH-RS 482, CNPHRS 546); à biovar 3 (CNPH-RS 403, CNPH-RS 507, CNPH-RS 510, CNPH-RS 541) e os isolados padrões de referência, K60, GMI1000, UW151, UW363 e UW386 (Tabela 4).

Para o ensaio, os isolados foram riscados e repicados como descrito anteriormente no tópico 2.2.1. Em uma placa de ELISA de 96 poços foram adicionados, em cada poço, $190 \mu \mathrm{L}$ de meio CPG e em seguida, $10 \mu \mathrm{L}$ de uma suspensão bacteriana de cada isolado, com absorbância checada previamente em espectrofotômetro em $0,1\left(\mathrm{OD}_{550 \mathrm{~nm}}\right)$. O experimento foi conduzido com triplicatas (repetições) para cada um dos 22 isolados das diferentes biovares. A placa foi então incubada em câmara de crescimento por 72 horas a $28^{\circ} \mathrm{C}$. Seguiu-se o protocolo de O'Toole \& Kolter (1998) com modificações. Após o período de crescimento, foi removido o meio de cultura com bactérias de cada poço, seguindo-se de três lavagens com $200 \mu \mathrm{L}$ de água Milli-Q cada e incubação por 2 horas a $60^{\circ} \mathrm{C}$ para secar os poços. Em seguida foram adicionados $150 \mu \mathrm{L}$ solução com cristal violeta a $0,3 \%$, com incubação por 45 minutos em temperatura ambiente. O corante foi então removido e repetiu-se a lavagem com água Milli-Q. A solubilização foi feita com $150 \mu \mathrm{L}$ de etanol-acetona (20\% de acetona) e, a medição, efetuada em leitor de ELISA com $485 \mathrm{~nm}$ de comprimento de onda. Os gráficos foram gerados e analisados pelo teste de Scott-Knott 5\%. 


\subsection{Sensibilidade in vitro a antibióticos}

Dezesseis antibióticos foram selecionados para a avaliação da sensibilidade in vitro de 47 isolados de $R$. solanacearum e do isolado CNPH-RS 488. Os antibióticos utilizados, com suas respectivas concentrações em microgramas por litro foram: ácido pipemídico (20); ampicilina (10); cefalotina (30); cefazolina (30); cefoxitina (30); ciprofloxacina (5); clindamicina (2); cloranfenicol (30); cotrimoxazol (25); eritromicina (15); norfloxacina (10); nitrofurantoina (300); oxacilina (1); penicilina G. (10); tetraciclina (30) e tobramicina (10).

Suspensões de cada isolado foram quantificadas em espectrofotômetro e ajustadas para a concentração de $10^{8} \mathrm{UFC} / \mathrm{mL}$. Meio Kelman foi vertido em placas de petri de $10 \mathrm{~cm}$ de diâmetro, em seguida, $10 \mathrm{~mL}$ de meio semi-sólido (0,5\% ágar) foi misturado com $5 \mathrm{~mL}$ da suspensão bacteriana e vertido sobre uma camada de meio Kelman. Os discos de antibióticos foram acondicionados e pressionados contra o meio semi-sólido e então, as placas foram postas em câmara de crescimento por 72 horas à $28^{\circ} \mathrm{C}$. Para as avaliações, o halo foi mensurado quanto ao seu diâmetro, considerando também o tamanho do disco de antibiótico.

O meio semi-seletivo SMART (Kawanishi et al., 2011) foi avaliado para os mesmos isolados. Este meio de cultura tem na sua composição os antibióticos polimixina B, ciclohexamida e cloranfenicol. Colônias puras de cada isolado foram riscadas em placas de meio sólido SMART subdivididas e permaneceram em câmara de crescimento por cinco dias (120 horas) com temperatura de $28^{\circ} \mathrm{C}$. Foram classificados como positivos aqueles isolados com crescimento visível de colônias de $R$. solanacearum.

\subsection{Resposta de uma gama de plantas hospedeiras a inoculações com o isolado}

\section{CNPH-RS 488}

Plantas de tomateiro (S. lycopersicum), berinjela (S. melongena), jiló (S. aethiopicum var. gilo), amendoim (Arachis hypogaea), gergelim (Sesamum indicum) e tagetes (Tagetes erecta) 
foram selecionadas para estudo da resposta à infecção por se tratarem de espécies já relatadas como suscetíveis ao CER, porém com níveis distintos de resistência. Para esse ensaio, cinco isolados foram selecionados: GMI1000 (raça 1/biovar 3), UW363 (raça 1/biovar 3), CNPH-RS 449 (raça 1/biovar 3), CNPH-RS 488 (raça 1/biovar 2A) e CNPH-RS 489 (raça 1/biovar 1)

(Tabela 4). O preparo dos isolados e do inóculo seguiram os mesmos procedimentos descritos no tópico 2.2.1. Quatro plantas para cada espécie por isolado foram inoculadas e mantidas em casa de vegetação com temperatura ente 20 e $40^{\circ} \mathrm{C}$ com aquecimento noturno, visando minimizar possíveis escapes. O delineamento experimental utilizado foi inteiramente casualizado, com quatro plantas por vaso. A avaliação da incidência de murcha nas plantas foi realizada aos 20 dias após a inoculação. Teste do copo (de fluxo bacteriano) foi feito visando confirmação da ausência de muco bacteriano em plantas assintomáticas.

\section{RESULTADOS}

\subsection{Caracterização da biovar e filotipo do isolado CNPH RS-488}

Para a análise da biovar, foi observada oxidação dos meios com celobiose, lactose, maltose e não oxidação dos alcoóis dulcitol, manitol e sorbitol, indicando que o isolado pertence à biovar 2. A ausência de oxidação dos meios contendo inositol e trealose indicou que o isolado pertence à biovar $2 \mathrm{~A}$.

No resultado da PCR multiplex para identificação dos filotipos, como descrito por Fegan \& Prior (2005), para o filotipo I é gerado um fragmento de $144 \mathrm{pb}$, para o filotipo II de $372 \mathrm{pb}$, para o filotipo III um amplicon de $91 \mathrm{pb}$ e para o filotipo IV um amplicon de $213 \mathrm{pb}$. O isolado CNPH-RS 488 foi caracterizado como filotipo II (Figura 2), resultado esperado após a identificação da biovar 2 que compõe o filotipo II. 


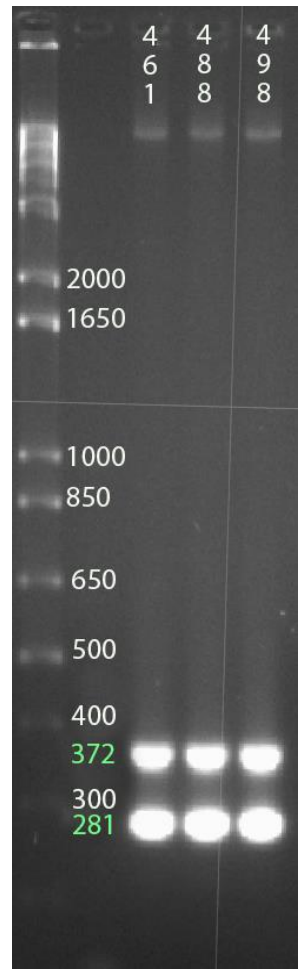

Figura 2. Gel de agarose (1\%) resultante da eletroforese dos produtos da PCR multiplex com os primers Nmult e o par 759/760 para identificação do filotipo e da espécie dos isolados CNPH-RS 461, CNPH-RS 488 e CNPH-RS 498. Eletroforese com o marcador 1kb plus, amplicon de $372 \mathrm{pb}$ indica o filotipo II. A presença do amplicon de $281 \mathrm{pb}$ confirma que o isolado é do complexo de espécies de Ralstonia.

\subsection{Teste de patogenicidade em tomateiro e batateira}

Todos os isolados foram capazes de causar murcha em 100\% das plantas da linhagem suscetível 'L390', confirmando suas virulências. Foi verificado nestes bioensaios que o isolado CNPH-RS 488 (raça 3/biovar 2A) é altamente virulento à linhagem 'Hawaii 7996'. Todos os isolados, com exceção do CNPH-RS 498, foram capazes de causar murcha em níveis superiores a 50\% das plantas da linhagem 'Hawaii 7996 (Tabela 5). No entanto, somente o isolado em destaque, CNPH-RS 488, causou murcha em $100 \%$ das plantas testadas. Na batateira suscetível 'Monalisa', somente o isolado CNPH-RS 534 não causou 100\% de murcha. 
Tabela 5. Percentagem de plantas apresentando sintomas de murcha em testes de patogenicidade conduzidos com quatro isolados de Ralstonia solanacearum (raça 3/biovar 2). Plantas de duas linhagens de tomateiro, 'L390' (suscetível) e 'Hawaii 7996' (resistente) e da batateira suscetível 'Monalisa' foram inoculadas pelo método de penetração do caule.

\begin{tabular}{|c|c|c|c|}
\hline & \multicolumn{2}{|c|}{ Tomateiro } & Batateira \\
\hline Isolados & $\begin{array}{c}\text { Suscetive } \\
\text { L390 }\end{array}$ & $\begin{array}{c}\text { Resistente } \\
\text { H7996 }\end{array}$ & $\begin{array}{l}\text { Suscetível } \\
\text { Monalisa }\end{array}$ \\
\hline CNPH-RS 461 & 100 & 62.5 & 100 \\
\hline CNPH-RS 488 & 100 & 100 & 100 \\
\hline CNPH-RS 498 & 100 & 0 & 100 \\
\hline CNPH-RS 534 & 100 & 50 & 25 \\
\hline
\end{tabular}

\subsection{Titulação de infectividade}

Todos os isolados foram capazes de causar sintomas de murcha na linhagem suscetível de tomateiro e no clone suscetível de batata (Figura 3; Tabela 5), porém com diferenças nos níveis de virulência.

Nas menores concentrações, de $10^{4} \mathrm{UFC} / \mathrm{mL}$ e $10^{5} \mathrm{UFC} / \mathrm{mL}$, nenhum dos isolados conseguiu induzir sintomas de murcha em nenhuma das duas linhagens contrastantes de tomateiro. Na concentração de $10^{6} \mathrm{UFC} / \mathrm{mL}$, um número reduzido de plantas apresentou sintomas de murcha. O isolado CNPH-RS 461 murchou 55,55\% das plantas da linhagem 'L390' contra 22,22\% de 'Hawaii 7996'. O isolado CNPH-RS 488 murchou 5,55\% de 'L390' contra zero em 'Hawaii 7996'. O isolado CNPH-RS 498 murchou 33,33\% de 'L390' e 11,11\% de 'Hawaii 7996'. O isolado CNPH-RS 534 murchou 5,55\% de 'L390' e zero em 'Hawaii 7996'. Já na concentração de $10^{7} \mathrm{UFC} / \mathrm{mL}$ houve um maior número de plantas murchas, para o isolado CNPH-RS 461, 77,77\% das plantas de 'L390' murcharam e 50\% em 'Hawaii 7996'. Para o isolado CNPH-RS 488, 94,44\% de plantas de 'L390' murcharam contra 77,77\% de 'Hawaii 7996'. O isolado CNPH-RS 534 murchou 50\% de plantas de 'L390' e 22,22\% de 'Hawaii 7996'. Na maior concentração, de $10^{8}$ UFC/mL, o isolado CNPH-RS 461 murchou 94,44\% das 
plantas de 'L390' e 50\% de 'Hawaii 7996'. O isolado CNPH-RS 488, com somente cinco dias após a inoculação (D.A.I.), murchou 94,44\% das plantas de 'L390' e em 9 D.A.I.100\% de 'Hawaii 7996'. O isolado CNH-RS 498, com sete D.A.I., murchou 88,88\% de ‘L390' e 77,77\% de 'Hawaii 7996'. Para o último isolado, CNPH-RS 534, 55,55\% das plantas de 'L390' murcharam e 61,11\% de 'Hawaii 7996'. A evolução das plantas murchas pelo isolado CNPHRS 488 foi mais rápida do que nos demais isolados, ao contrário do isolado CNPH-RS 534 que evolui lentamente, murchando um reduzido número de plantas de ambas as linhagens inoculadas (Figura 3).

Para a análise dos resultados da titulação de infectividade, foi estabelecido o limiar baseado no número de D.A.I. para um isolado causar 50\% de murcha nas plantas de cada uma das linhagens. Na concentração mais elevada, para a linhagem 'Hawaii 7996', o CNPH-RS 488 conseguiu suplantar o próximo isolado, CNPH-RS 498, em 2 D.A.I. e em 3 D.A.I. para os demais isolados. Para 'L390', o CNPH-RS 488 superou o isolado com similar virulência, CNPH-RS 498, em 1 D.A.I. em 2 D.A.I. para o isolado CNPH-RS 461 e 7 D.A.I. para o CNPHRS 534. Em comparação entre as linhagens, a 'Hawaii 7996' somente alcançou o limiar de 2 D.A.I. depois da linhagem 'L390', para o isolado CNPH-RS 488, 3 D.A.I. para o CNPH-RS 498, 4 D.A.I. para o CNPH-RS 461 e menos 2 D.A.I. para o CNPH-RS 534. 

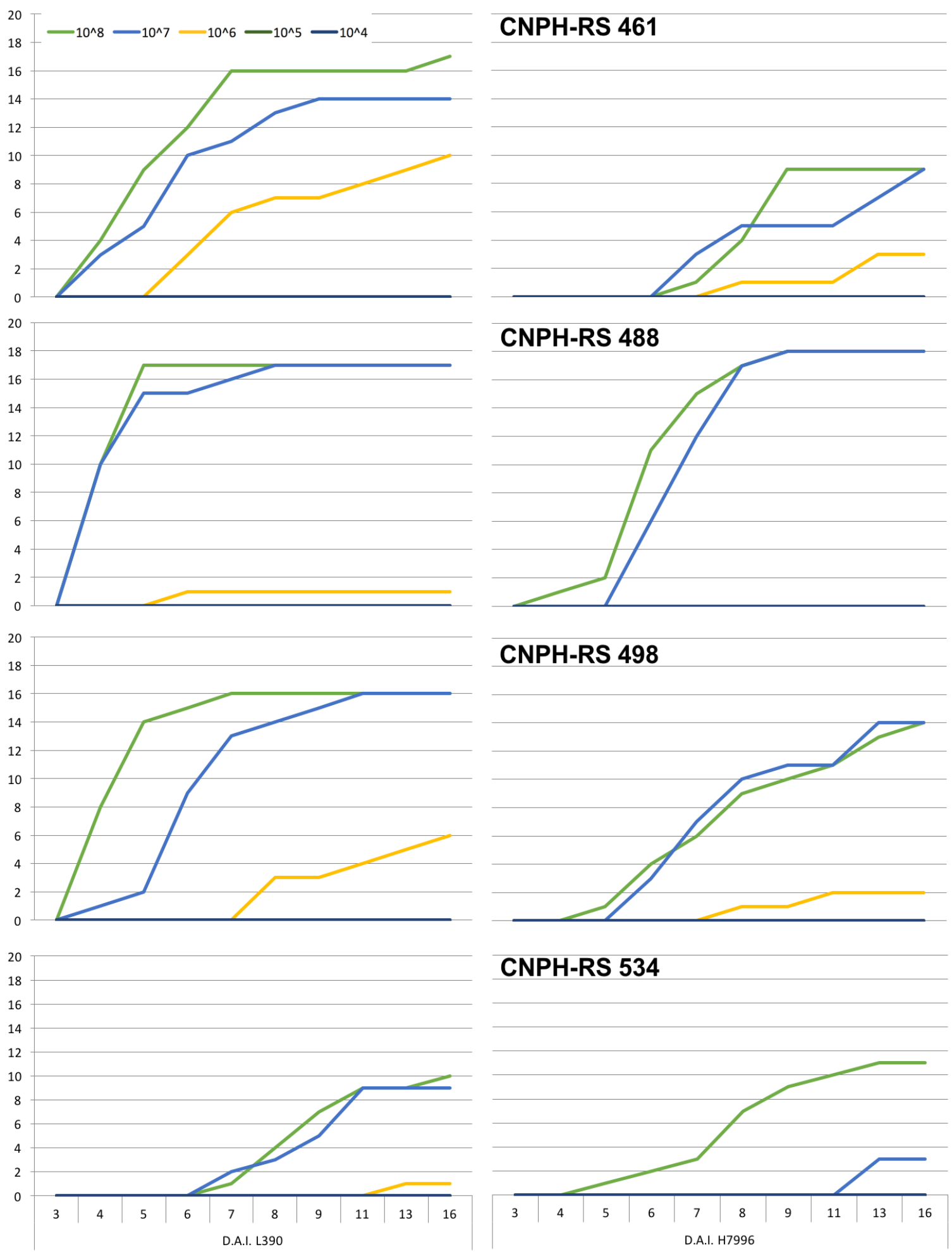

\section{CNPH-RS 498}

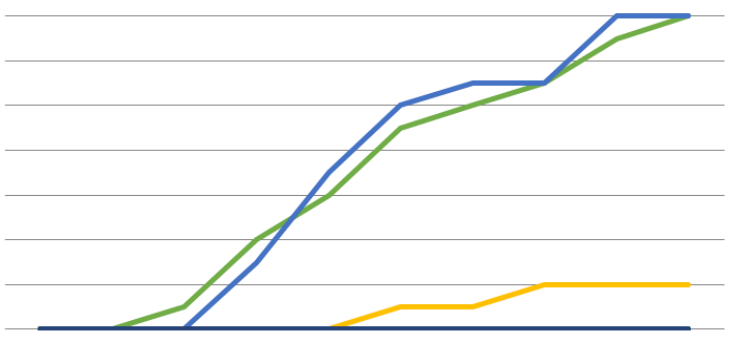

CNPH-RS 534

Figura 3. Titulação de infectividade das linhagens de tomateiro 'L390' (suscetível) e 'Hawaii 7996' (resistente) avaliadas com cinco concentrações de inóculo de quatro isolados de Ralstonia solanacearum (CNPH-RS 461, CNPH-RS 488, CNPH-RS 498, CNPH-RS 534). As plantas foram avaliadas dos três até os 16 dias após a inoculação. As cores representam os resultados obtidos com as diferentes concentrações de inóculo. Eixo vertical representa o 
número absoluto de plantas murchas enquanto o horizontal o número de dias após a inoculação (D.A.I.). O método de Inoculação utilizado foi de borrifamento das raízes com aproximadamente $4 \mathrm{~mL}$ de suspensão bacteriana.

\subsection{Produção de EPS}

A quantidade de EPS produzida pelos diferentes isolados em análise apresentou diferenças significativas (Scott-Knott 5\%). CNPH-RS 429 foi o isolado que apresentou maior produção de EPS, seguido dos isolados CNPH-RS 488, CNPH-RS 461 e GMI1000 (Figura 4). Outro grupo foi formado pelos isolados CNPH-RS 506 e K60. Os isolados CNPH-RS 541,CNPH-RS 498 e CNPH-RS 534 foram os que apresentaram a menor produção de EPS. Os dados de produção foram analisados usando uma curva padrão com $\mathrm{R}^{2}$ de 0,998 , indicando bom ajuste aos dados, e a equação $y=103,6 x-7,1535$. 


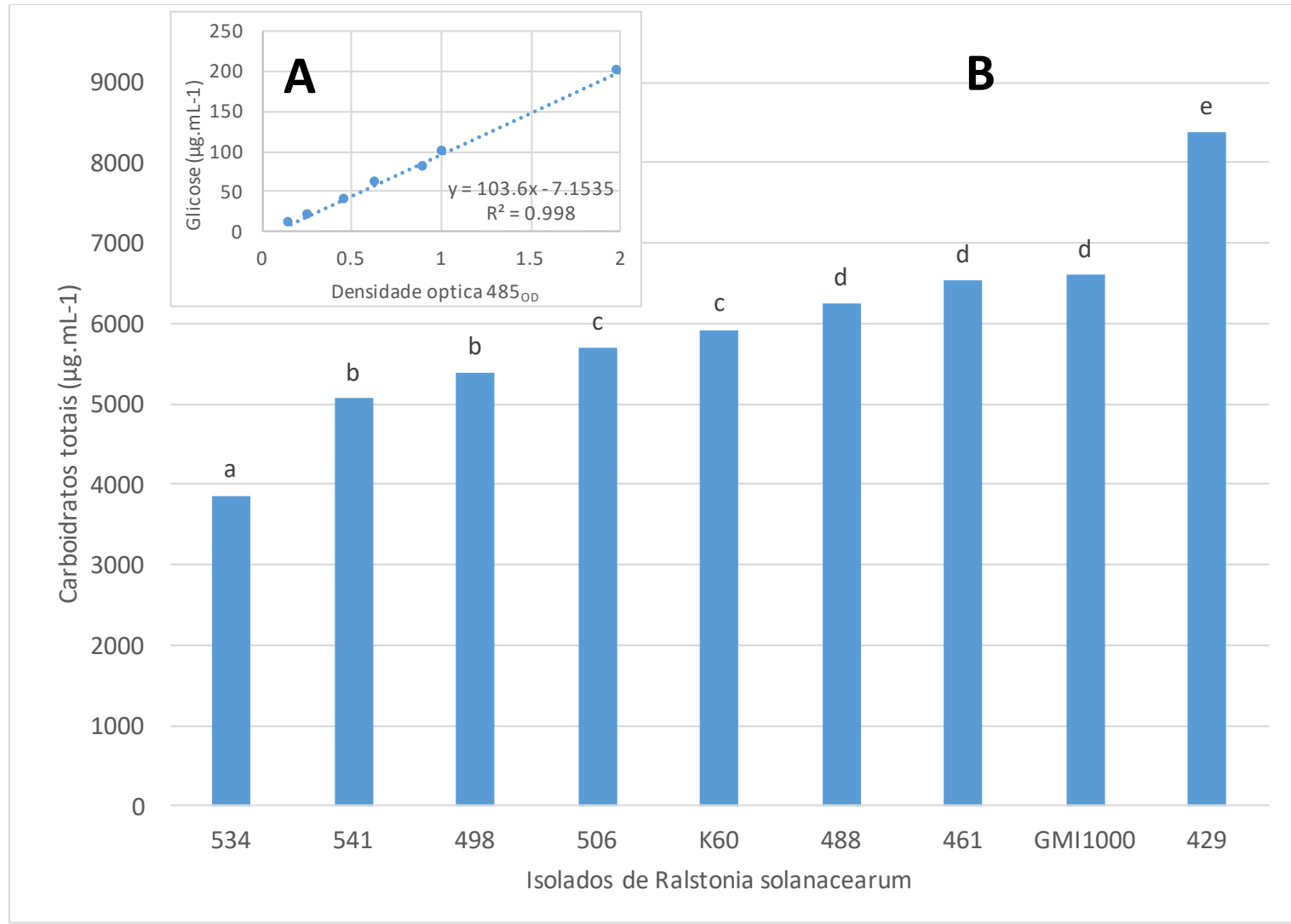

Figura 4. Variação na produção de exopolissacarídeo (EPS) por diferentes isolados do complexo de espécies de Ralstonia. A - Curva de calibração para estimativa da concentração de carboidratos totais. B - Médias das estimadas das concentrações de carboidratos totais nos diferentes isolados do complexo de espécies de Ralstonia. Médias seguidas por diferentes letras em cada coluna diferiram estatisticamente, entre si, para o teste de Scott-Knott (5\% de probabilidade).

\subsection{Produção de biofilme}

Após 72 horas, foi possível observar diferenças significativas de produção de biofilme. Pela análise de Scott-Knott ao nível de significância de 5\%, os isolados foram divididos em três grupos (Figura 5). O primeiro grupo foi composto por isolados que produziram as menores quantidades de biofilme (K60, UW551, CNPH-RS 429, CNPH-RS 461, CNPH-RS 482, CNPH-RS 488, CNPH-RS 507, CNPH-RS 506, CNPH-RS 534, CNPH-RS 537, CNPH-RS 541 e CNPH-RS 546). O segundo grupo foi composto por isolados com produção intermediária de 
biofilme (CNPH-RS 77, CNPH-RS 403, CNPH-RS 443, CNPH-RS 460, CNPH-RS 498, CNPH-RS 501 e CNPH-RS 510). O terceiro grupo foi formado por isolados de elevada produção de biofilme (GMI1000, UW363 e UW386).

Os isolados da biovar 1 apresentaram produção intermediária de biofilme; enquanto que os isolados da biovar 2A, incluindo o isolado CNPH-RS 488, se posicionaram no grupo com baixa produção. A única exceção dentro do grupo de isolados da biovar 2A foi CNPH-RS 498. Os isolados da biovar 2T apresentaram variações, sendo que dois dos três isolados agruparam com os que menos produziram, com exceção do isolado CNPH-RS 77 com produção intermediária. Dois dos quatro isolados biovar 3 foram identificados com capacidade de produção de biofilme intermediária, e o isolado CNPH-RS 507 com produção menor. Os isolados de referência oscilaram dentro dos grupos, tendendo ao grupo com a mais alta produção de biofilme.

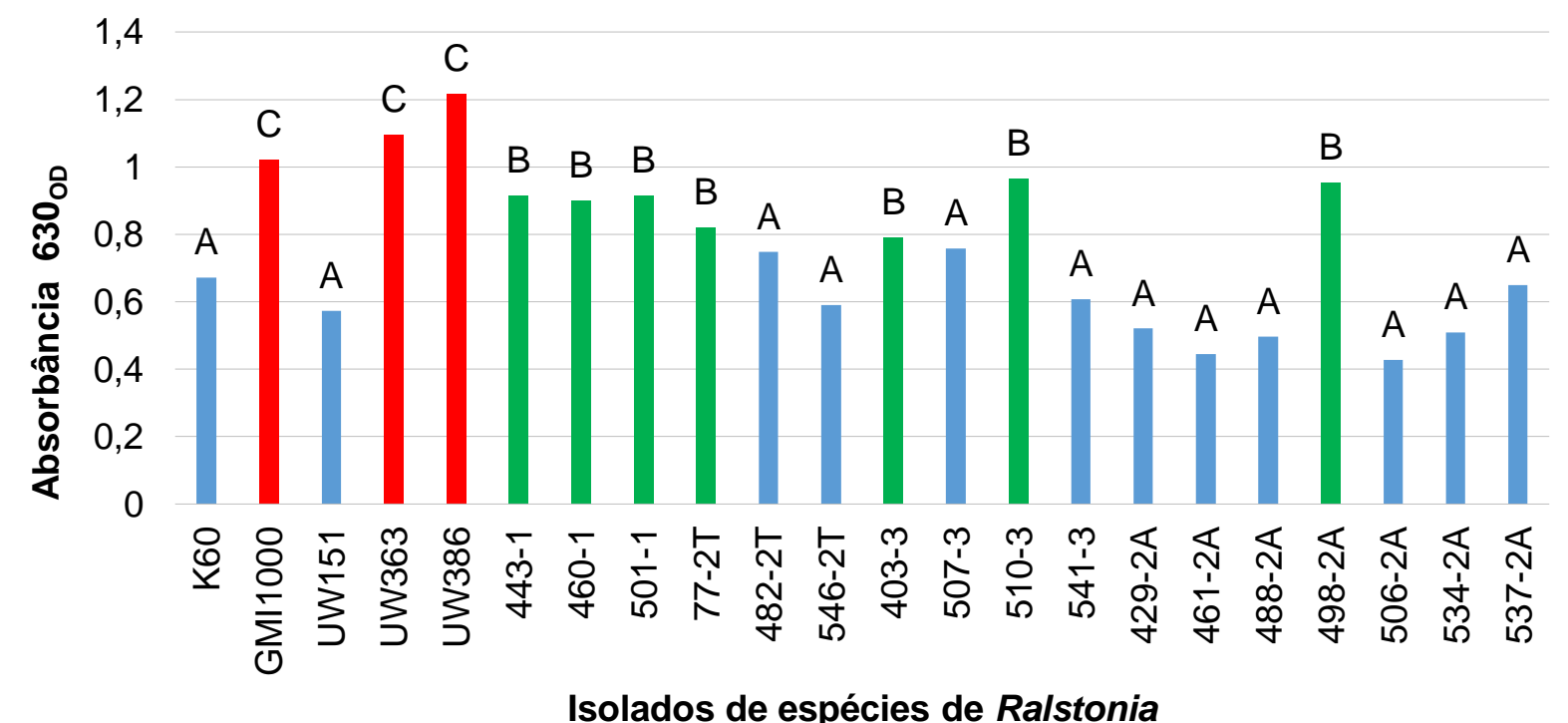

Figura 5. Quantificação da produção de biofilme por isolados do complexo de espécies de Ralstonia de diferentes filotipos e biovares com análise estatística por teste de Scott-Knott a $5 \%$ de probabilidade. 


\subsection{Sensibilidade in vitro a antibióticos}

No teste do meio semi-seletivo SMART, ocorreu o crescimento dos isolados de biovar 3 no meio, não ocorrendo o mesmo com isolados de biovares 1, 2A e 2T (Tabela 6). Para os 16 antibióticos usados no antibiograma, somente clindamicina e oxacilina não inibiram nenhum dos isolados. A nitrofurantoina inibiu cinco isolados, CNPH-RS 12, CNPH-RS 66, CNPH-RS 71, CNPH-RS 77, CNPH-RS 94, CNPH-RS 437. A penicilina inibiu 25 isolados (CNPH-RS 12, CNPH-RS 44, CNPH-RS 59, CNPH-RS 66, CNPH-RS 67, CNPH-RS 94, CNPH-RS 313, CNPH-RS 403, CNPH-RS 429, CNPH-RS 433, CNPH-RS 437, CNPH-RS 449, CNPH-RS 461, CNPH-RS 481, CNPH-RS 482, CNPH-RS 488, CNPH-RS 498, CNPH-RS 501, CNPHRS 508, CNPH-RS 510, CNPH-RS 534, CNPH-RS 541 e CNPH-RS 546). Os isolados da biovar 2A apresentaram um padrão diferenciado, sendo menos suscetíveis à cefalotina, com seis dos oito isolados classificados como resistentes, já para os antibióticos ampicilina e cefazolina, cinco dos oito não foram inibidos. O isolado CNPH-RS 488 (que também é de biovar 2A) foi sensível à cefazolina e não aos outros dois antibióticos destacados.

Tabela 6. Resposta de sensibilidade in vitro de 48 isolados de quatro biovares (1, 2A, 2T e 3 ) do complexo de espécies de Ralstonia a 16 antibióticos e ao meio semi-seletivo SMART de (Kawanishi et al., 2011). (+) = crescimento; (-) = inibição de crescimento. Os números na tabela representam o diâmetro do halo de inibição em centímetros.

\begin{tabular}{|c|c|c|c|c|c|c|c|c|c|c|c|c|c|c|c|c|c|c|}
\hline 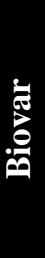 & 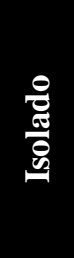 & 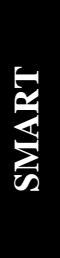 & 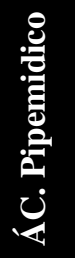 & 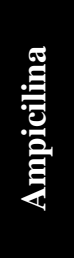 & 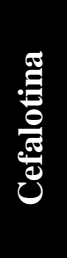 & 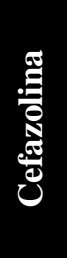 & 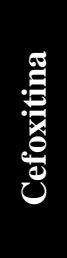 & 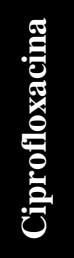 & 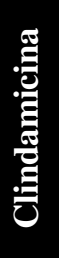 & 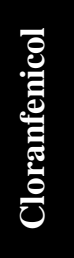 & 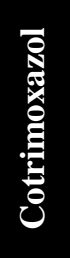 & 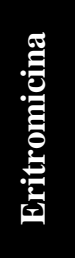 & 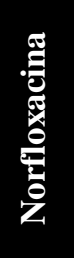 & 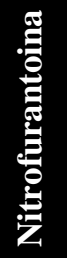 & 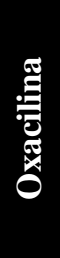 & 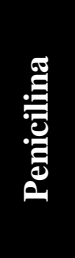 & 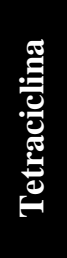 & 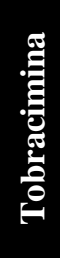 \\
\hline 1 & 433 & - & 1,3 & 1,3 & 0,7 & 0,7 & 1,4 & 3,1 & 0 & 1,6 & 1,3 & 2 & 2,7 & 0 & 0 & 0 & 2,7 & 1,7 \\
\hline 1 & 436 & - & 1,6 & 2 & 1,5 & 1,5 & 1,6 & 3,1 & 0 & 1,6 & 1,9 & 2,4 & 2,7 & 0 & 0 & 1,1 & 3 & 1,8 \\
\hline 1 & 460 & - & 1,5 & 2,4 & 1,7 & 1,9 & 2 & 3,8 & 0 & 1,9 & 2,3 & 2,1 & 3,2 & 0 & 0 & 1,2 & 3,2 & 1,7 \\
\hline 1 & 501 & - & 2,3 & 1,9 & 1,3 & 1,7 & 1,8 & 3,6 & 0 & 1,6 & 1,9 & 1,9 & 3,2 & 0 & 0 & 0 & 3,1 & 1,7 \\
\hline 1 & 518 & - & 1,9 & 2,1 & 1,4 & 1,5 & 1,7 & 4,3 & 0 & 1,6 & 2,6 & 2,5 & 2,9 & 0 & 0 & 1,1 & 3,6 & 1,9 \\
\hline 1 & 522 & - & 1,9 & 1,9 & 1,4 & 1,5 & 1,7 & 3 & 0 & 1,6 & 1,7 & 2,1 & 2,4 & 0 & 0 & 1 & 2,9 & 1,9 \\
\hline 1 & 533 & - & 1,8 & 1,5 & 1,1 & 1,3 & 0 & 3 & 0 & 1,7 & 1,9 & 1,9 & 2,3 & 0 & 0 & 1 & 3 & \\
\hline
\end{tabular}




\begin{tabular}{|c|c|c|c|c|c|c|c|c|c|c|c|c|c|c|c|c|c|c|}
\hline 1 & 536 & - & 1,9 & 2 & 1,1 & 1,6 & 1,9 & 3,7 & 0 & 1,6 & 2,5 & 2,8 & 3,1 & 0 & 0 & 1,5 & 3,3 & 2,3 \\
\hline 1 & 545 & - & 1,8 & 1,8 & 1,1 & 1,6 & 1,7 & 3,3 & 0 & 1,9 & 1,6 & 2,2 & 2,5 & 0 & 0 & 1,1 & 3,2 & 2 \\
\hline $2 \mathrm{~A}$ & 12 & - & 0 & 2,5 & 2,1 & 2 & 2 & 2,3 & 0 & 1,5 & 2,3 & 2 & 1,9 & 1 & 0 & 0 & 4,5 & 1,1 \\
\hline $2 \mathrm{~A}$ & 429 & - & 1,4 & 0 & 0 & 0 & 2,3 & 2,7 & 0 & 1,3 & 2 & 1,5 & 2,7 & 0 & 0 & 0 & 3,2 & 1,4 \\
\hline $2 \mathrm{~A}$ & 437 & - & 1,6 & 1 & 0 & 0 & 1,8 & 2,5 & 0 & 1,6 & 2,8 & 1,4 & 2,5 & 1 & 0 & 0 & 3,5 & 1,4 \\
\hline $2 \mathrm{~A}$ & 461 & - & 1 & 0 & 0 & 0 & 1,7 & 3 & 0 & 1,9 & 2,5 & 1,3 & 2,5 & 0 & 0 & 0 & 3 & 1,3 \\
\hline $2 \mathrm{~A}$ & 488 & - & 1,5 & 0 & 0 & 1 & 1,9 & 3 & 0 & 1,4 & 1,8 & 1,5 & 3 & 0 & 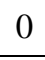 & 0 & 3 & 1,3 \\
\hline $2 \mathrm{~A}$ & 498 & - & 1,5 & 0 & 0 & 0 & 0 & 2,6 & 0 & 1,9 & 2 & 2 & 2,8 & 0 & 0 & 0 & 2,8 & 1,5 \\
\hline $2 \mathrm{~A}$ & 534 & - & 1,3 & 0 & 0 & 0,1 & 1,3 & 2,5 & 0 & 2 & 2,2 & 1,8 & 2,5 & 0 & U & 0 & 3,2 & 1,3 \\
\hline $2 \mathrm{~A}$ & 541 & - & 1,3 & 0,8 & 0,9 & 0 & 0 & 2,5 & 0 & 2,4 & 1,5 & 2 & 2,3 & 0 & 0 & 0 & 3,2 & 1,6 \\
\hline $2 \mathrm{~T}$ & 44 & - & 0,8 & 2,3 & 1,2 & 1,2 & 1,7 & 2,7 & 0 & 1,9 & 2,3 & 1,6 & 2,3 & 0 & 0 & 0 & 2,8 & 1,5 \\
\hline $2 \mathrm{~T}$ & 59 & - & 1,2 & 2 & 0 & 0 & 1 & 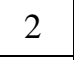 & 0 & 1,9 & 1,7 & 2 & 2,1 & 0 & 0 & 0 & 2,8 & 1,4 \\
\hline $2 \mathrm{~T}$ & 66 & - & 2,6 & 1,6 & 0 & 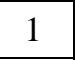 & 0 & 4,5 & 0 & 1,2 & 1,8 & 0 & 4 & 1 & 0 & 0 & 2,8 & 2 \\
\hline $2 \mathrm{~T}$ & 67 & - & 1,4 & 1,8 & 0 & 1,2 & 0 & 3,4 & 0 & 2 & 1,7 & 1,8 & 2,3 & 0 & 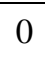 & 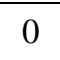 & 2,8 & 1,3 \\
\hline $2 \mathrm{~T}$ & 71 & - & 1,5 & 2,3 & 1 & 1,1 & 1,4 & 3,2 & 0 & 1,8 & 1,8 & 8 & 2,3 & 4 & 0 & 0,8 & 2,9 & 1,2 \\
\hline $2 \mathrm{~T}$ & 77 & - & 1 & 2,4 & 1,4 & 1,4 & 1,9 & 2,7 & 0 & 2,1 & 2 & 4 & 2,2 & 1,5 & 0 & 1 & 2,8 & 1,6 \\
\hline $2 \mathrm{~T}$ & 94 & - & 1,2 & 1,5 & 1,2 & 1, & 1 & 2 & ( & 1 & 1,6 & 1,9 & 2,1 & 1,1 & & 0 & 2,4 & 1,5 \\
\hline $2 \mathrm{~T}$ & 478 & - & 1,2 & 1,7 & 1,2 & 1,2 & 1 & 2 , & 0 & 1 & 2 & 1,9 & 2,5 & 0 & & 1,2 & 2,5 & 1,4 \\
\hline $2 \mathrm{~T}$ & 4 & - & 0,9 & 1,7 & 0 & 0 & 0 & 2,6 & 0 & 1,5 & 2,3 & 1,2 & 2 & 0 & 0 & 0 & 2,6 & 1,6 \\
\hline $2 \mathrm{~T}$ & 482 & - & 1 & 1,7 & 0 & 0 & 0 & 2,7 & 0 & 1,7 & 2,2 & 1,6 & 2 & 0 & 0 & 0 & 2,6 & 1,5 \\
\hline $2 \mathrm{~T}$ & 546 & - & 3,3 & 1,7 & 1,1 & 1,2 & 0,8 & 4 & 0 & 1,5 & 2,1 & 0 & 3,6 & 0 & 0 & 0 & 2,5 & 1,6 \\
\hline 3 & 15 & + & 1,6 & 2,4 & 1,8 & 1,7 & 1,8 & 3,3 & 0 & 2,3 & 3,3 & 2,6 & 2,7 & 0 & 0 & 1,8 & 3,6 & 2 \\
\hline 3 & 18 & + & 2,4 & 2,1 & 1,4 & 1,3 & 1,5 & 2,3 & 0 & 2,4 & 1,6 & 2,3 & 1,8 & 0 & 0 & 0,7 & 3 & 2,2 \\
\hline 3 & 198 & + & 1,4 & 2 & 1,4 & 1,4 & 1,4 & 2,7 & 0 & 2,1 & 2,3 & 2,4 & 2 & 0 & 0 & 0,9 & 3,4 & 1,9 \\
\hline 3 & 313 & + & 1,7 & 1,9 & 1,3 & 1,4 & 0 & 2,8 & 0 & 2,5 & 2 & 2,3 & 2,4 & 0 & 0 & 0 & 3,3 & 1,9 \\
\hline 3 & 318 & + & 2 & 2,3 & 1,1 & 1,7 & 1,7 & 3 & 0 & 2,5 & 2,5 & 2,8 & 2,8 & 0 & 0 & 1,2 & 3,5 & 2,2 \\
\hline 3 & 321 & + & 1,4 & 1,9 & 1,4 & 1,6 & 1,5 & 2,5 & 0 & 2,3 & 2,3 & 2,3 & 2,2 & 0 & 0 & 1,1 & 2,9 & 2,3 \\
\hline 3 & 322 & + & 1,5 & 2 & 1,2 & 1,7 & 0 & 2,7 & 0 & 2,4 & 1,8 & 2,4 & 2,2 & 0 & 0 & 1 & 3,4 & 2,4 \\
\hline 3 & 3 & + & 1,8 & 2 & 1,1 & 1,3 & 0 & 2,3 & 0 & 2,3 & 2,8 & 2,7 & 0 & 0 & 0 & 1,1 & 3,4 & 1,9 \\
\hline 3 & 4 & + & 1 & 1,8 & 1, & 1,4 & 0 & 2,6 & 0 & 1,7 & 1,6 & 8 & 2,1 & 0 & 0 & 0 & 3,3 & 2,1 \\
\hline 3 & 4 & + & 1, & 1,0 & 1, & 1,2 & 0 & 2, & 0 & 2,1 & 1,5 & 2 & 1, & 0 & 0 & 0 & 3,3 & 2,3 \\
\hline 3 & 4 & + & 1, & 2 & 0,9 & 1, & 2,1 & 3 & 0 & 1,8 & 2,3 & 2,2 & 2,8 & 0 & $\sigma$ & 1,1 & 3,4 & 2 \\
\hline 3 & 4 & - & 1, & 2,1 & 1, & 1,3 & 1 & 3 & 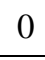 & 1,5 & 2 & 2,5 & 3 & 0 & 0 & 1,2 & 3,4 & 2 \\
\hline 3 & 4 & + & 0 & 2 & 1,1 & ${ }_{2}$ & 1,8 & 2,7 & 0 & 1 & 2,2 & 2,5 & 2, & 0 & 0 & 5 & 3,4 & 1,9 \\
\hline 3 & 47 & + & 0,8 & 1,9 & 1,6 & 16 & 1,2 & 3 & $\sigma$ & 2,8 & 1,7 & 2,2 & 2,5 & 0 & 0 & 1 & 3,4 & 2,1 \\
\hline 3 & $\mathbf{5 0 7}$ & - & 1,1 & 1 & 1,4 & 1,2 & 0 & 2,8 & 0 & 2, & 1,8 & 2,3 & 2,4 & 0 & 0 & 0,8 & 3,3 & 2,1 \\
\hline 3 & 5 & + & 1,3 & 1,5 & 0 & 1 & 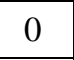 & 3 & 0 & 1,9 & 1,5 & 2 & 2,3 & 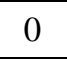 & 0 & 0 & 3,1 & 1,9 \\
\hline 3 & 510 & + & 1 & 1,8 & 1,5 & 1,5 & 1,7 & 3,1 & 0 & 2,5 & 2,2 & 2,8 & 2,4 & 0 & 0 & 0 & 3,4 & 2,3 \\
\hline 3 & 54 & + & 1,1 & 1 & 1 & 0,9 & 0 & 2,6 & 0 & 1,8 & 1,6 & 2,5 & 2,1 & 0 & 0 & 0 & 3,2 & 1 \\
\hline 3 & 551 & + & 1,8 & 2 & 1,4 & 1,5 & 1,8 & 2,5 & 0 & 2,9 & 2,1 & 2,4 & 2 & 0 & 0 & 4 & 3,4 & 2,4 \\
\hline 3 & 556 & + & 2 & 1,8 & 1 & 1,4 & 0 & 3 & 0 & 2,7 & 2,3 & 2,6 & 2,5 & 0 & 0 & 0,5 & 3,3 & 2 \\
\hline
\end{tabular}




\subsection{Perfil de virulência em uma gama de plantas hospedeiras}

Todos os isolados demonstraram ser virulentos, induzindo murcha em pelo menos três das seis hospedeiras inoculadas (Figura 6). O isolado CNPH-RS 488 causou murcha em 100\% das plantas de berinjela e tomate e $50 \%$ das plantas de jiló. No entanto, esse isolado não induziu sintomas em plantas de amendoim, gergelim e tagetes.

Os isolados GMI1000 e UW363 (biovar 3) não induziram murcha em amendoim, gergelim e tagetes. O isolado GMI1000 também não induziu murcha em plantas de jiló. O isolado CNPH-RS 449 (biovar 1) causou sintomas de murcha em berinjela, amendoim, jiló e gergelim, sem causar doença em tagetes.

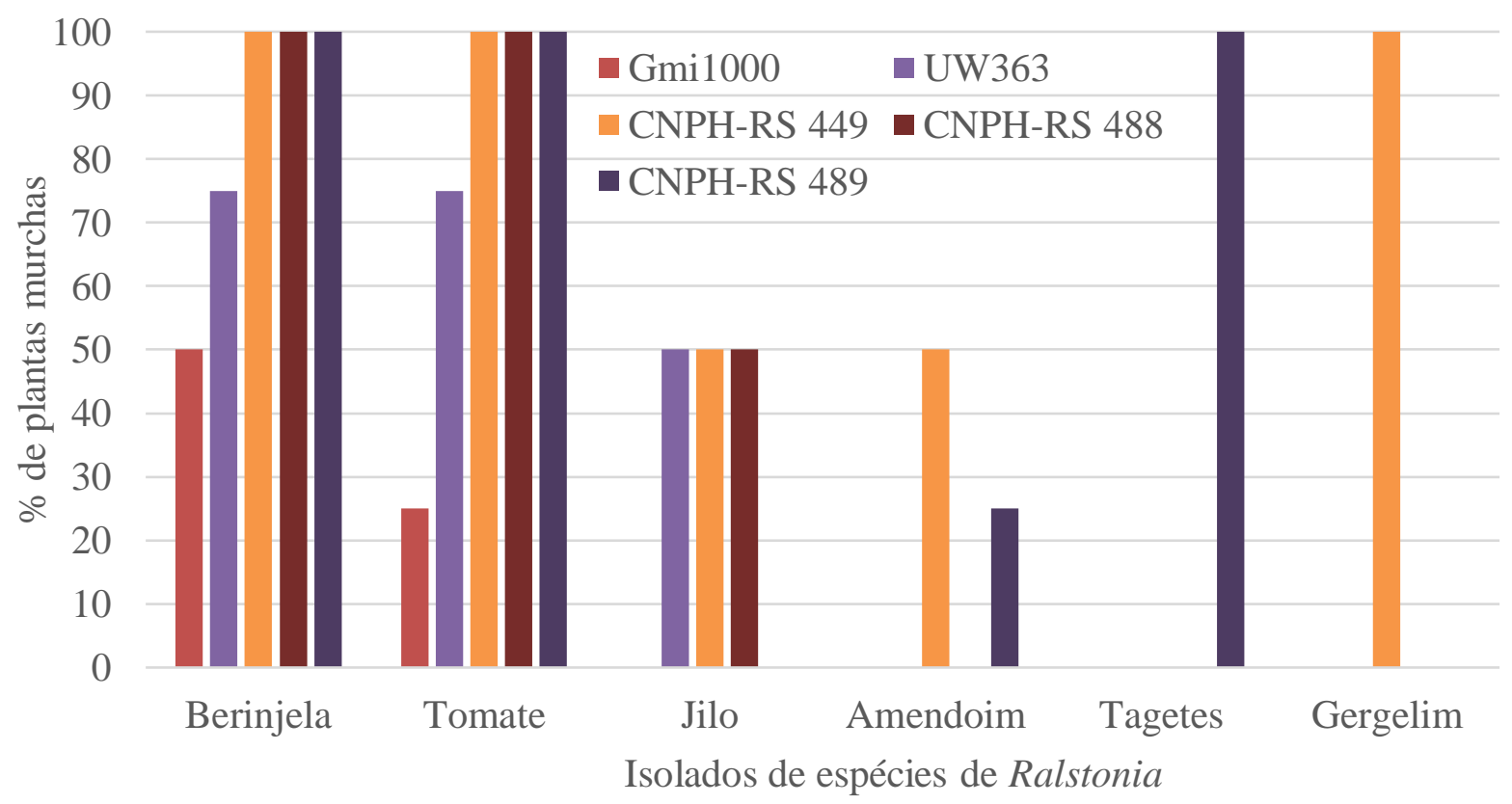

Figura 6. Porcentagem (incidência) de plantas murchas aos 20 dias após a inoculação de seis hospedeiras (berinjela, tomate, jiló, amendoim, tagetes e gergelim) inoculadas com cinco isolados do complexo de espécies de Ralstonia. 


\section{DISCUSSÃO}

Conforme esperado, com base em relatos de vários autores, foram observadas diferenças nos níveis de virulência entre os isolados do CER e nos níveis de resistência das linhagens 'Hawaii 7996' e 'L390'. Os isolados de R. solanacearum e R. pseudosolanacearum avaliados no presente trabalho apresentaram elevados níveis de virulência, sendo capazes de induzir frequencias elevadas de plantas com sintomas de murcha nos acessos suscetíveis de tomateiro e batata. Uma resposta mais ampla e variada foi observada no perfil de virulência de alguns isolados que foram capazes de infectar a linhagem de tomateiro resistente ('Hawaii 7996'). No caso do germoplasma do tomateiro, o acesso 'Hawaii 7996' é considerado a fonte de resistência com maior estabilidade e amplitude (Scott et al., 2004).

Os dados apresentados no presente trabalho estão de acordo com os observados por Carmeille et al. (2006a) e Lebeau et al. (2011), em que genótipos de tomateiro apresentam suscetibilidade similar à batata aos isolados de raça 3/biovar 2A, também apresentando elevado número de plantas murchas. Esse é um dado de interesse, uma vez que o foco do melhoramento genético do tomateiro tem sido identificar e incorporar resistência para isolados da raça 1/biovar 1, que são mais frequentemente observados infectando essa cultura.

Outra observação feita por Carmeille et al. (2006a) foi que a linhagem 'Hawaii 7996' representa uma das poucas resistências descritas para raça 3/biovar 2, porém já existindo casos reportados de suplantação dessa resistência (Milling et al., 2011; Genin \& Denny, 2012). Essa capacidade de “quebrar” a resistência da linhagem 'Hawaii 7996' foi também encontrada no isolado CNPH-RS 488. Por essa razão, procurou-se identificar quais mecanismos/características poderiam explicar tal perfil de virulência. Para isso, foram conduzidos estudos mais detalhados sobre a titulação de infectividade, produção de EPS e produção de biofilme. 
As diferenças no tempo necessário para cada isolado causar 50\% de plantas murchas em cada linhagem, demonstrou as diferenças entre os isolados, em especial do isolado capaz de suplantar a resistência do 'Hawaii 7996', CNPH-RS 488.

No presente estudo, as concentrações de $10^{8}$ e $10^{7} \mathrm{UFC} / \mathrm{mL}$ não apresentaram marcantes diferenças na capacidade de induzir doença, porém foi possível identificar as diferenças entre os isolados para a quebra de resistência da linhagem 'Hawaii 7996' e também na diferença de virulência. As concentrações utilizadas na titulação de infectividade demonstram que essas influenciam, de maneira consistente, as respostas dos diferentes genótipos resistentes e suscetíveis. De acordo com os dados obtidos por Carmeille et al. (2006b), a concentração de $10^{7} \mathrm{UFC} / \mathrm{mL}$ foi suficiente para induzir doença e minimizar escapes. O sistema quorum sensing, responsável pelo controle tanto da patogênese quanto do metabolismo bacteriano (Schell, 2000; Genin et al., 2005), é uma das hipóteses formuladas para explicar a observação de que apenas as concentrações mais elevadas foram capazes de induzir doença. Em bactérias, o sistema de quorum sensing depende do acúmulo de células até um determinado limiar, quando se iniciam alguns processos que podem ser de patogênese ou latência (Liu et al., 2008).

Schell (2000) indica que a concentração de $10^{9} \mathrm{UFC} / \mathrm{mL}$ no tecido da planta é capaz de induzir a doença e a produção de fatores de patogênese como o EPS e outras enzimas. Milling et al. (2011) relatam que plantas de 'Hawaii 7996' inoculadas com concentrações de $1 \times 10^{7}$ UFC de $R$. solanacearum por grama de tecido do caule, tiveram suas respostas de defesa fortemente ativadas pelas rotas metabólicas do ácido salicílico e etileno, enquanto que plantas suscetíveis não apresentaram resposta alguma. De acordo com os mesmos autores, o isolado UW551 de $R$. solanacearum (biovar 2) causou um nível significativo de doença na linhagem resistente 'Hawaii 7996' quando comparado com o isolado GMI1000 (biovar 3). Porém, no presente trabalho, a linhagem 'Hawaii 7996' foi desafiada com diversos outros isolados biovar 2, comprovando que o isolado CNPH-RS 488 apresenta capacidade superior de suplantar a 
resistência dessa linhagem, indicando que pode ser uma característica do tipo isoladoespecífica.

A bactéria $R$. solanacearum continua seu desenvolvimento no tecido infectado durante a evolução da doença, levando a formação de colônias e de biofilme (Morris \& Monier, 2003; Kumar et al., 2015). A produção de biofilme entre os isolados avaliados oscilou, formando três grupos estatísticos distintos. A maioria dos isolados da biovar 2A (inclusive o CNPH-RS 488) apresentou baixa e/ou mais lenta produção de biofilme. Peeters et al. (2013) destaca a importância do biofilme para a que a doença ocorra, porém a observação realizada neste trabalho indica que a rápida produção de biofilme não está necessariamente associada com níveis elevados de virulência e/ou mais amplo perfil de virulência.

De fato, existem poucos estudos relacionando a produção de biofilme e a virulência, em especial aqueles que relacionam tempo para formação ou quantidade com a capacidade de induzir a doença (Yao \& Allen, 2007). Estudos sobre mutantes defectivos para os genes de pilli tipo IV ou EPS (em que a capacidade de adesão na superfície da célula hospedeira foi anulada) resultaram em uma perda quase completa da virulência. No entanto, esses estudos não analisaram outros fatores como o tempo para formação de biofilme e/ou quantidade de biofilme produzido (Rigano et al., 2007). Kang et al. (2002) observaram que mutantes pilA, que não formam biofilme de forma similar ao tipo selvagem, são hipovirulentos. Em outros patossistemas como o do patógeno Burkholderia pseudomallei não foi identificada a relação entre a quantidade de biofilme produzido e virulência (Taweechaisupapong et al., 2005).

Os dados de produção de biofilme e da titulação de infectividade não apresentaram uma clara associação. O isolado CNPH-RS 498, mesmo com maior produção de biofilme que o CNPH-RS 488, causou menos doença. Por sua vez, o isolado CNPH-RS 534, que agrupou com 
o CNPH-RS 488 na quantidade de biofilme, causou muito menos doença, quando consideramos tanto o tempo como a incidência.

Outro fator de patogênese que pode explicar a capacidade diferencial do isolado CNPHRS 488 é o EPS, reconhecido como essencial para o processo infectivo de Ralstonia (Milling et al., 2011; Murthy \& Srinivas, 2015). De acordo com a análise estatística do teste colorimétrico foram observados cinco grupos, ficando o isolado CNPH-RS 488 agrupado com outro isolado de elevada virulência, o CNPH-RS 461. No entanto, ambos foram caracterizados com uma produção de EPS de quantidade intermediária. Esse dado pode indicar que a capacidade diferencial de patogênese pode estar associada com a composição do EPS e não com a quantidade produzida ou velocidade de produção. Embora o CER apresente uma extrema diversidade, o EPS (que representa a principal matriz do biofilme) se apresenta conservado na sua composição, o que tem permitindo o uso de anticorpos específicos com abrangência suficiente para cobrir, supostamente, toda a diversidade dentro do CER (Alvarez, 2004). Segundo Milling et al. (2011), o EPS tem função de proteção contra os sistemas de defesa da planta, evitando a detecção do patógeno pela hospedeira. No entanto, o EPS apresenta um efeito contrário na fonte de resistência 'Hawaii 7996' uma vez que sua presença aciona as respostas de defesa dessa linhagem (Milling et al., 2011). Diferenças entre os isolados avaliados não foram identificadas, sugerindo que a composição e não o volume produzido de EPS pode ser determinante para o reconhecimento e ativação dos processos de defesa por parte da linhagem resistente 'Hawaii 7996'. Porém, somente uma análise qualitativa por meio da técnica de espectrometria de massa poderá responder se diferenças na capacidade de patogênese do isolado CNPH-RS 488 estão relacionadas com a composição do EPS.

Como descrito anteriormente, as alterações estruturais do EPS são pouco prováveis devido à sua elevada conservação evolucionária. Dessa forma, é possível que, como citado por Milling et al. (2011), outros elicitores estejam envolvidos. Essa hipótese é plausível do ponto 
de vista de variabilidade genômica entre isolados uma vez que diferenças foram observadas em cerca de 1000 genes entre análises comparativas de um isolado da biovar 3 (GMI1000) e um isolado da biovar 2 (UW551). Outro obstáculo no estudo do EPS é o fato de ser geneticamente regulado por um operon de $18 \mathrm{~kb}$ que envolve a mobilização de diversas enzimas que processam os seus carboidratos estruturais (Huang \& Schell, 1995).

O EPS tem sido pobremente estudado, se limitando à análise da quantidade produzida (McGarvey et al., 1999), porém, o fato de ser o principal elicitor de defesa no tomateiro 'Hawaii 7996' à infecção do CER demanda estudos adicionais (Alvarez, 2004; Milling et al., 2011). Por outro lado, os dados obtidos no presente estudo indicam, de modo geral, a necessidade de serem explorados outros fatores de virulência e não somente o biofilme ou a produção de EPS. A virulência e fatores de patogenicidade do CER são considerados complexos, dificultando um amplo entendimento do processo.

O meio semi-seletivo SMART permitiu apenas o crescimento de isolados da biovar 3. Já as biovares 1,2A, 2T não se desenvolveram, confirmando que o uso desse meio de cultura para as condições brasileiras não irá ter sucesso assegurado na recuperação dos isolados do CER presentes no país. Outros meios que usam a mesma composição de antibióticos ou, em alguns casos, mais que os três usados como o SMSA (Elphinstone et al., 1996) e CIPEB (Priou et al., 2006), também não serão capazes de permitir o isolamento da bactéria devido à similaridade de composição com o meio semi-seletivo SMART.

Os meios semi-seletivos ajudam na recuperação da bactéria, já que muitas vezes o objetivo é a obtenção de um isolado para testes futuros, tanto bioquímicos como para emprego em sistemas de seleção de fontes resistência em germoplasma de plantas hospedeiras. Para o teste de antibiograma, os antibióticos clindamicina e oxacilina, por não terem efeito inibitório algum nos isolados usados, podem ser potencialmente empregados em meios seletivos. A 
penicilina e nitrofurantoina não inibiram alguns isolados, e podem, desta forma, ter suas concentrações ajustadas para serem também aplicados em meios semi-seletivos que visem o isolamento de um número mais amplo de isolados do CER. O cloranfenicol, geralmente usado para inibir o desenvolvimento de fungos nos meios semi-seletivos, é também usado nos meios SMSA, SMART e CIPEB. No antibiograma conduzido no presente trabalho, o cloranfenicol causou inibição aos isolados empregados, sendo um dos prováveis agentes que explicam o feito inibitório do meio semi-seletivo SMART aos isolados brasileiros do CER. Para o isolado CNPH-RS 488 e os demais da biovar 2A, foram observadas diferenças nos antibióticos que não inibiram seu desenvolvimento, como o ocorrido com cefalotina e ampicilina, indicando que esse grupo apresenta um espectro de resistência contra um número maior de antibióticos quando comparado com as demais biovares.

Para o teste com a gama de hospedeiros, as espécies foram selecionadas por não serem relatadas como suscetíveis a isolados da biovar 2A. O jiló, berinjela, amendoim e gergelim são geralmente associados à suscetibilidade à biovar 3 (Collonnier et al., 2001; Gousset et al., 2005; Ivey et al., 2007; Jeong et al., 2007; Xu et al., 2009), assim como o Tagetes à biovar 1 (Mondal et al., 2011). O emprego de plantas de Tagetes tem sido relatado como uma possível estratégia no controle da murcha bacteriana via rotação em solos infestados (Terblanche \& De Villiers, 1998; Hooks et al., 2010). No entanto, a suscetibilidade de acessos de Tagetes já foi confirmada contra isolados da biovar 2 (Pradhanang et al., 2000). No presente trabalho, o teste do copo em Tagetes indicou que as plantas assintomáticas não apresentaram elevadas concentrações da bactéria como ocorre em infecções latentes em gerânios.

Isolados da biovar 2A, ao contrário daqueles da biovar 1 e biovar 3, apresentam uma menor gama de plantas hospedeiras (Cellier \& Prior, 2010), destacando-se principalmente as perdas que pode causar em batata, tomate e potencial para infecções latentes em gerânio e batata (Swanson et al., 2007). O isolado CNPH-RS 488 apresentou uma gama de hospedeiras mais 
restrita do que os isolados da biovar 1 e biovar 3, não sendo capaz de causar murcha em plantas de amendoim, Tagetes e gergelim, que são consideradas hospedeiras não convencionais no Brasil. Mesmo existindo relatos da biovar 2 causando murcha em Tagetes, isso não foi observado com o isolado CNPH-RS 488 (Pradhanang et al., 2000). No caso de tomate, jiló e berinjela (especialmente essas duas últimas hospedeiras) aparentemente são mais suscetíveis aos isolados da biovar 3. No entanto, o isolado CNPH-RS 488 causou o mesmo índice de murcha que os isolados das biovares 1 e 3 nas três hospedeiras. Foram também observados níveis maiores de resistência no jiló, como previamente descrito por Lopes et al. (2015), que sugerem o seu potencial uso como porta-enxerto. Esse resultado serve como alerta para o não uso de solanáceas mesmo para áreas com a presença de isolados de $R$. solanacearum (previamente raça 3/biovar 2). O fato do isolado GMI1000 (biovar 3) não ter causado sintomas, pode ser explicado pela perda de virulência devido ao seu armazenamento por longos períodos (Genin et al., 2005).

\section{CONCLUSÕES}

- O isolado CNPH-RS 488, embora pertença à raça 3/biovar 2A, normalmente associada à cultura da batata, representa uma nova variante de isolados de $R$. solanacearum, com elevada virulência e apresentando a capacidade de superação de fatores da resistência em tomate;

- O isolado CNPH-RS 488 foi capaz de superar a resistência da linhagem 'Hawaii 7996' e conseguiu (em comparação com os demais isolados de biovar 2) induzir sintomas de murcha mais rapidamente, tanto para o próprio 'Hawaii 7996' como também para a linhagem suscetível 'L390';

- Produção de EPS e biofilme não apresentaram correlações claras com o perfil de virulência mais amplo do isolado CNPH-RS 488; 
- Isolados brasileiros do CER, assim como o foco desse estudo, o isolado CNPH-RS 488, apresentaram seu crescimento inibido em meios semi-seletivos como SMART e SMSA, indicando não ser adequado para o isolamento nas condições brasileiras;

- O perfil de antibiograma indica a possibilidade de desenvolvimento de um meio mais eficiente combinando os antibióticos oxacilina, clindamicina e nitrofurantoina, em associação com outros antibióticos;

- Os isolados com perfil de virulência similares aos observados para o isolado CNPH-RS 488 além de oferecerem potenciais riscos à produção de tomate, devido à capacidade de infectar as principais fontes de resistência nas duas hospedeiras, também têm capacidade de infectar distintas plantas hospedeiras consideradas mais resistentes à raça 3/biovar 2, tais como jiló e berinjela.

\section{PERSPECTIVAS}

- Sequenciar o genoma completo do isolado CNPH-RS 488;

- Buscar entre os efetores possíveis respostas para a suplantação de resistência;

- Realizar um estudo qualitativo da composição do EPS do isolado CNPH-RS 488.

\section{REFERENCIAS BIBLIOGRÁFICAS}

ALVAREZ, A.M. 2004. Integrated approaches for detection of plant pathogenic bacteria and diagnosis of bacterial diseases. Annual Review of Phytopathology 42:339-366.

BI-HAO, C.; JIAN-JUN, L.; YONG, W. \& GUO-JU, C. 2009. Inheritance and identification of SCAR marker linked to bacterial wilt-resistance in eggplant. African Journal of Biotechnology 8.

BRUMBLEY, S.M. \& DENNY, T.P. 1990. Cloning of wild-type Pseudomonas solanacearum phcA, a gene that when mutated alters expression of multiple traits that contribute to virulence. Journal of Bacteriology 172:5677-5685.

BUDDENHAGEN, I.W.; SEQUEIRA, L. \& KELMAN, A. 1962. Designation of races of Pseudomonas solanacearum. Phytopathology 52:726-730. 
CARDOSO, S.C.; SOARES, A.C.F.; BRITO, A.D.S.; CARVALHO, L.A.D. \& LEDO, C.A.D.S. 2006. Potential of Hawaii 7996 hybrid as rootstock for tomato cultivars. Bragantia 65:89-96.

CARMEILlE, A.; CARANTA, C.; DINTINGER, J.; PRIOR, P.; LUISETTI, J. \& BESSE, P. 2006a. Identification of QTLs for Ralstonia solanacearum race 3-phylotype II resistance in tomato. Theoretical and Applied Genetics 113:110-121.

CARMEILlE, A.; PRIOR, P.; KODJA, H.; CHIROLEU, F.; LUISETTI, J. \& BESSE, P. 2006b. Evaluation of resistance to race 3, biovar 2 of Ralstonia solanacearum in tomato germplasm. Journal of Phytopathology 154:398-402.

CELLIER, G. \& PRIOR, P. 2010. Deciphering phenotypic diversity of Ralstonia solanacearum strains pathogenic to potato. Phytopathology 100:1250-1261.

CHAMPOISEAU, P.G.; JONES, J.B. \& ALLEN, C. 2009. Ralstonia solanacearum race 3 biovar 2 causes tropical losses and temperate anxieties. Plant Health Progress 10:1-10.

COHAN, F.M. 2006. Towards a conceptual and operational union of bacterial systematics, ecology, and evolution. Philosophical Transactions of the Royal Society of London B: Biological Sciences 361:1985-1996.

COLLONNIER, C.; MULYA, K.; FOCK, I.; MARISKA, I.; SERVAES, A.; VEDEL, F.; SILJAK-YAKOVLEV, S.; SOUVANNAVONG, V.; DUCREUX, G. \& SIHACHAKR, D. 2001. Source of resistance against Ralstonia solanacearum in fertile somatic hybrids of eggplant (Solanum melongena L.) with Solanum aethiopicum L. Plant Science 160:301-313.

DEBERDT, P.; GOZÉ, E.; CORANSON - BEAUDU, R.; PERRIN, B.; FERNANDES, P.; LUCAS, P. \& RATNADASS, A. 2015. Crotalaria spectabilis and Raphanus sativus as Previous Crops Show Promise for the Control of Bacterial Wilt of Tomato Without Reducing Bacterial Populations. Journal of Phytopathology 163:377-385.

DUBOIS, M.; GILLES, K.A.; HAMILTON, J.K.; REBERS, P. \& SMITH, F. 1956. Colorimetric method for determination of sugars and related substances. Analytical chemistry 28:350-356.

ELPHINSTONE, J.G.; HENNESSY, J.; WILSON, J.K. \& STEAD, D.E. 1996. Sensitivity of different methods for the detection of Ralstonia solanacearum in potato tuber extracts. EPPO Bulletin 26:663-678.

ELSHARKAWY, M.M.; NAKATANI, M.; NISHIMURA, M.; ARAKAWA, T.; SHIMIZU, M. \& HYAKUMACHI, M. 2015. Control of tomato bacterial wilt and root-knot diseases by Bacillus thuringiensis CR-371 and Streptomyces avermectinius NBRC14893. Acta Agriculturae Scandinavica, Section B-Soil \& Plant Science 5:1-6. 
FEGAN, M. \& PRIOR, P. 2005. How complex is the Ralstonia solanacearum species complex? In: ALLEN, C.; PRIOR, P. \& HAYWARD, A.C. eds. Bacterial wilt disease and the Ralstonia solanacearum species complex.1 ed.APS Press. Estados Unidos. p. 449-461.

GENIN, S. 2010. Molecular traits controlling host range and adaptation to plants in Ralstonia solanacearum. New Phytologist 187:920-928.

GENIN, S.; BRITO, B.; DENNY, T.P. \& BOUCHER, C. 2005. Control of the Ralstonia solanacearum Type III secretion system (Hrp) genes by the global virulence regulator PhcA. FEBS letters 579:2077-2081.

GENIN, S. \& DENNY, T.P. 2012. Pathogenomics of the Ralstonia solanacearum species complex. Annual Review of Phytopathology 50:67-89.

GOUSSET, C.; COLLONNIER, C.; MULYA, K.; MARISKA, I.; ROTINO, G.L.; BESSE, P.; SERVAES, A. \& SIHACHAKR, D. 2005. Solanum torvum, as a useful source of resistance against bacterial and fungal diseases for improvement of eggplant $(S$. melongena L.). Plant Science 168:319-327.

GRIMAULT, V.; PRIOR, P. \& ANAIS, G. 1995. A monogenic dominant resistance of tomato to bacterial wilt in Hawaii 7996 is associated with plant colonization by Pseudomonas solanacearum. Journal of Phytopathology 143:349-352.

HAYWARD, A.C. 1991. Biology and Epidemiology of a bacterial wilt caused by Pseudomonas solanacearum. Annual Review of Phytopathology 29:14.

HAYWARD, A.C. 1994. The hosts of Pseudomonas solanacearum. In: HAYWARD, A.C. \& HARTMAN, G.L. eds. Pseudomonas solanacearum: The disease and its causative agent.1 ed.CABI International. Reino Unido. p. 101-115.

HONG, J.C.; MOMOL, M.T.; JONES, J.B.; JI, P.; OLSON, S.M.; ALLEN, C.; PEREZ, A.; PRADHANANG, P. \& GUVEN, K. 2008. Detection of Ralstonia solanacearum in irrigation ponds and aquatic weeds associated with the ponds in North Florida. Plant Disease 92:1674-1682.

HOOKS, C.R.R.; WANG, K.-H.; PLOEG, A. \& MCSORLEY, R. 2010. Using marigold (Tagetes spp.) as a cover crop to protect crops from plant-parasitic nematodes. Applied Soil Ecology 46:307-320.

HUANG, J. \& SCHELL, M. 1995. Molecular characterization of the eps gene cluster of Pseudomonas solanacearum and its transcriptional regulation at a single promoter. Molecular Microbiology 16:977-989.

HYAKUMACHI, M.; NISHIMURA, M.; ARAKAWA, T.; ASANO, S.; YOSHIDA, S.; TSUSHIMA, S. \& TAKAHASHI, H. 2013. Bacillus thuringiensis suppresses bacterial wilt disease caused by Ralstonia solanacearum with systemic induction of defenserelated gene expression in tomato. Microbes and Environments 28:128-134. 
IMAZAKI, I. \& NAKAHO, K. 2010. Pyruvate-amended modified SMSA medium: improved sensitivity for detection of Ralstonia solanacearum. Journal of General Plant Pathology 76:52-61.

IVEY, M.L.L.; GARDENER, B.B.M.; OPINA, N. \& MILLER, S.A. 2007. Diversity of Ralstonia solanacearum infecting eggplant in the Philippines. Phytopathology 97:14671475 .

JEONG, Y.; KIM, J.; KANG, Y.; LEE, S. \& HWANG, I. 2007. Genetic diversity and distribution of Korean isolates of Ralstonia solanacearum. Plant Disease 91:1277-1287.

JIANWEI, L.; HUIFANG, J.; XIAOPING, R.; XIAOJIE, Z. \& BOSHOU, L. 2010. Identification and molecular traits of ICRISAT mini core collection of peanut species with resistance to bacterial wilt. Chinese Agriculture Science Bulletin 26:47-51.

KANG, Y.; LIU, H.; GENIN, S.; SCHELL, M.A. \& DENNY, T.P. 2002. Ralstonia solanacearum requires type 4 pili to adhere to multiple surfaces and for natural transformation and virulence. Molecular Microbiology 46:427-437.

KAWANISHI, T.; SHIRAISHI, T.; OKANO, Y.; SUGAWARA, K.; HASHIMOTO, M.; MAEJIMA, K.; KOMATSU, K.; KAKIZAWA, S.; YAMAJI, Y. \& HAMAMOTO, H. 2011. New detection systems of bacteria using highly selective media designed by SMART: selective medium-design algorithm restricted by two constraints. PloS One 6:e16512.

KELMAN, A. 1954. The relationship of pathogenicity in Pseudomonas solanacearum to colony appearance on a tetrazolium medium. Phytopathology 44:693-695.

KIM, S.G.; HUR, O.-S.; RO, N.-Y.; KO, H.-C.; RHEE, J.-H.; SUNG, J.S.; RYU, K.-Y.; LEE, S.-Y. \& BAEK, H.J. 2016. Evaluation of Resistance to Ralstonia solanacearum in Tomato Genetic Resources at Seedling Stage. The Plant Pathology Journal 32:58-64.

KUMAR, J.S.; UMESHA, S.; PRASAD, K.S. \& NIRANJANA, P. 2016. Detection of Quorum Sensing Molecules and Biofilm Formation in Ralstonia solanacearum. Current Microbiology 72:297-305.

LEBEAU, A.; DAUNAY, M.C.; FRARY, A.; PALLOIX, A.; WANG, J.F.; DINTINGER, J.; CHIROLEU, F.; WICKER, E. \& PRIOR, P. 2011. Bacterial wilt resistance in tomato, pepper, and eggplant: genetic resources respond to diverse strains in the Ralstonia solanacearum species complex. Phytopathology 101:154-165.

LIU, H.; COULTHURST, S.J.; PRITCHARD, L.; HEDLEY, P.E.; RAVENSDALE, M.; HUMPHRIS, S.; BURR, T.; TAKLE, G.; BRURBERG, M.-B. \& BIRCH, P.R.J. 2008. Quorum sensing coordinates brute force and stealth modes of infection in the plant pathogen Pectobacterium atrosepticum. PLoS Pathogens 4:e1000093. 
LIU, L.; SUN, C.; LIU, S.; CHAI, R.; HUANG, W.; LIU, X.; TANG, C. \& ZHANG, Y. 2015. Bioorganic Fertilizer Enhances Soil Suppressive Capacity against Bacterial Wilt of Tomato. PloS One 10:e012304.

LIU, L.; SUN, C.; LIU, X.; HE, X.; LIU, M.; WU, H.; TANG, C.; JIN, C. \& ZHANG, Y. 2016. Effect of calcium cyanamide, ammonium bicarbonate and lime mixture, and ammonia water on survival of Ralstonia solanacearum and microbial community. Scientific reports 6.

LOPES, C.A. 2005. Murchadeira da batata. 1 Ed. Associação Brasileira da Batata. Itapetininga.

LOPES, C.A. 2015. Bacterial Wilt - a disease threatening disease of tomato cultivated under warm temperatures. Comunicado Técnico 109:4.

LOPES, C.A.; BOITEUX, L.S. \& ESCHEMBACK, V. 2015. Eficácia relativa de portaenxertos comerciais de tomateiro no controle da murcha-bacteriana. Horticultura Brasileira 33:125-130.

MALAVOLTA, J.; BERIAM, L.; ALMEIDA, I.; RODRIGUES NETO, J. \& ROBBS, C. 2008. Bactérias fitopatogênicas assinaladas no Brasil: uma atualização. Summa Phytopathologica 34:9-87.

MCGARVEY, J.A.; DENNY, T.P. \& SCHELL, M.A. 1999. Spatial-temporal and quantitative analysis of growth and EPS I production by Ralstonia solanacearum in resistant and susceptible tomato cultivars. Phytopathology 89:1233-1239.

MILLING, A.; BABUJEE, L. \& ALLEN, C. 2011. Ralstonia solanacearum extracellular polysaccharide is a specific elicitor of defense responses in wilt-resistant tomato plants. PloS One 6:e15853.

MONDAL, B.; BHATTACHARYA, I. \& KHATUA, D.C. 2011. Crop and weed host of Ralstonia solanacearum in West Bengal. Journal of Crop and Weed 7:195-199.

MORI, Y.; INOUE, K.; IKEDA, K.; NAKAYASHIKI, H.; HIGASHIMOTO, C.; OHNISHI, K.; KIBA, A. \& HIKICHI, Y. 2015. The vascular plant pathogenic bacterium Ralstonia solanacearum produces biofilms required for its virulence on the surfaces of tomato cells adjacent to intercellular spaces. Molecular Plant Pathology 17:890-902.

MORRIS, C.E. \& MONIER, J.-M. 2003. The ecological significance of biofilm formation by plant-associated bacteria. Annual Review of Phytopathology 41:429-453.

MURTHY, K.N. \& SRINIVAS, C. 2015. Extraction and characterization of extracellular polysaccharide from Ralstonia solanacearum causing wilt of tomato. International Journal of Agricultural Science and Research (IJASR) 5:81-92. 
NAKAHO, K.; INOUE, H.; TAKAYAMA, T. \& MIYAGAWA, H. 2004. Distribution and multiplication of Ralstonia solanacearum in tomato plants with resistance derived from different origins. Journal of General Plant Pathology 70:115-119.

O'TOOLE, G.A. \& KOLTER, R. 1998. Initiation of biofilm formation in Pseudomonas fluorescens WCS365 proceeds via multiple, convergent signalling pathways: a genetic analysis. Molecular Microbiology 28:449-461.

PEETERS, N.; GUIDOT, A.; VAILLEAU, F. \& VALLS, M. 2013. Ralstonia solanacearum, a widespread bacterial plant pathogen in the post - genomic era. Molecular Plant Pathology 14:651-662.

PLENER, L.; BOISTARD, P.; GONZÁLEZ, A.; BOUCHER, C. \& GENIN, S. 2012. Metabolic adaptation of Ralstonia solanacearum during plant infection: a methionine biosynthesis case study. PloS One 7:e36877-e36877.

PRADHANANG, P.M.; ELPHINSTONE, J.G. \& FOX, R.T.V. 2000. Identification of crop and weed hosts of Ralstonia solanacearum biovar 2 in the hills of Nepal. Plant Pathology 49:403-413.

PRIOU, S.; GUTARRA, L. \& ALEY, P. 2006. An improved enrichment broth for the sensitive detection of Ralstonia solanacearum (biovars 1 and 2A) in soil using DAS-ELISA. Plant Pathology 55:36-45.

RICA, C. 1983. A new selective medium for Pseudomonas solanacearum. Plant Disease 67:1084-1088.

RIGANO, L.A.; SICILIANO, F.; ENRIQUE, R.; SENDÍN, L.; FILIPPONE, P.; TORRES, P.S.; QÜESTA, J.; DOW, J.M.; CASTAGNARO, A.P. \& VOJNOV, A.A. 2007. Biofilm formation, epiphytic fitness, and canker development in Xanthomonas axonopodis $p v$. citri. Molecular Plant-Microbe Interactions 20:1222-1230.

RIVARD, C.L.; O'CONNELL, S.; PEET, M.M.; WELKER, R.M. \& LOUWS, F.J. 2012. Grafting tomato to manage bacterial wilt caused by Ralstonia solanacearum in the southeastern United States. Plant Disease 96:973-978.

SAFNI, I.; CLEENWERCK, I.; DE VOS, P.; FEGAN, M.; SLY, L. \& KAPPLER, U. 2014. Polyphasic taxonomic revision of the Ralstonia solanacearum species complex: proposal to emend the descriptions of Ralstonia solanacearum and Ralstonia syzygii and reclassify current $R$. syzygii strains as Ralstonia syzygii subsp. syzygii subsp. nov., $R$. solanacearum phylotype IV strains as Ralstonia syzygii subsp. indonesiensis subsp. nov., banana blood disease bacterium strains as Ralstonia syzygii subsp. celebesensis subsp. nov. and $R$. solanacearum phylotype I and III strains as Ralstonia pseudosolanacearum sp. nov. International Journal of Systematic and Evolutionary Microbiology 64:3087-3103. 
SANTIAGO, T.R.; LOPES, C.A.; CAETANO - ANOLLÉS, G. \& MIZUBUTI, E.S.G. 2016. Phylotype and sequevar variability of Ralstonia solanacearum in Brazil, an ancient center of diversity of the pathogen. Plant Pathology.

SCHELL, M.A. 2000. Control of virulence and pathogenicity genes of Ralstonia solanacearum by an elaborate sensory network. Annual Review of Phytopathology 38:263-292.

SCOTT, J.W.; WANG, J.F. \& HANSON, P.M. Breeding tomatoes for resistance to bacterial wilt, a global view. Proceedings of the I International Symposium on Tomato Diseases 695, 2004, 161-172.

SINGH, D.; SINHA, S.; YADAV, D.K. \& CHAUDHARY, G. 2014. Detection of Ralstonia solanacearum from asymptomatic tomato plants, irrigation water, and soil through nonselective enrichment medium with hrp gene-based bio-PCR. Current Microbiology 69:127-134.

SOOD, A.K. \& KUMAR, P. 2015. Evaluation of essential oils against Ralstonia solanacearum causing bacterial wilt of solanaceous crops. Plant Disease Research 30:67-72.

STRANGE, R.N. \& SCOTT, P.R. 2005. Plant disease: a threat to global food security. Phytopathology 43:83-116.

SWANSON, J.K.; MONTES, L.; MEJIA, L. \& ALLEN, C. 2007. Detection of latent infections of Ralstonia solanacearum race 3 biovar 2 in geranium. Plant Disease 91:828-834.

TAWEECHAISUPAPONG, S.; KAEWPA, C.; ARUNYANART, C.; KANLA, P.; HOMCHAMPA, P.; SIRISINHA, S.; PROUNGVITAYA, T. \& WONGRATANACHEEWIN, S. 2005. Virulence of Burkholderia pseudomallei does not correlate with biofilm formation. Microbial Pathogenesis 39:77-85.

TERBLANCHE, J. \& DE VILLIERS, D.A. 1998. The suppression of Ralstonia solanacearum by marigolds. In. Bacterial Wilt Disease. 1 ed.Springer. Alemanha. p. 325-331.

VALLS, M.; GENIN, S. \& BOUCHER, C. 2006. Integrated regulation of the type III secretion system and other virulence determinants in Ralstonia solanacearum. PLoS Pathogens 2:e82-e99.

VAN ELSAS, J.D.; KASTELEIN, P.; VAN BEKKUM, P.; VAN DER WOLF, J.M.; DE VRIES, P.M. \& VAN OVERBEEK, L.S. 2000. Survival of Ralstonia solanacearum biovar 2, the causative agent of potato brown rot, in field and microcosm soils in temperate climates. Phytopathology 90:1358-1366.

WAIRURI, C.K.; VAN DER WAALS, J.E.; VAN SCHALKWYK, A. \& THERON, J. 2012. Ralstonia solanacearum needs Flp pili for virulence on potato. Molecular Plant-Microbe Interactions 25:546-556. 
WANG, J.-F.; OLIVIER, J.; THOQUET, P.; MANGIN, B.; SAUVIAC, L. \& GRIMSLEY, N.H. 2000. Resistance of tomato line Hawaii7996 to Ralstonia solanacearum Pss4 in Taiwan is controlled mainly by a major strain-specific locus. Molecular Plant-Microbe Interactions 13:6-13.

WICKER, E.; GRASSART, L.; CORANSON-BEAUDU, R.; MIAN, D.; GUILBAUD, C.; FEGAN, M. \& PRIOR, P. 2007. Ralstonia solanacearum strains from Martinique (French West Indies) exhibiting a new pathogenic potential. Applied and Environmental Microbiology 73:6790-6801.

WICKER, E.; LEFEUVRE, P.; DE CAMBIAIRE, J.-C.; LEMAIRE, C.; POUSSIER, S. \& PRIOR, P. 2012. Contrasting recombination patterns and demographic histories of the plant pathogen Ralstonia solanacearum inferred from MLSA. The ISME Journal 6:961974.

WU, K.; YUAN, S.; XUN, G.; SHI, W.; PAN, B.; GUAN, H.; SHEN, B. \& SHEN, Q. 2015. Root exudates from two tobacco cultivars affect colonization of Ralstonia solanacearum and the disease index. European Journal of Plant Pathology 141:667-677.

XU, J.; PAN, Z.; PRIOR, P.; XU, J.; ZHANG, Z.; ZHANG, H.; ZHANG, L.; HE, L. \& FENG, J. 2009. Genetic diversity of Ralstonia solanacearum strains from China. European Journal of Plant Pathology 125:641-653.

YABUUCHI, E.; KOSAKO, Y.; YANO, I.; HOTTA, H. \& NISHIUCHI, Y. 1995. Transfer of two Burkholderia and an Alcaligenes species to Ralstonia gen. nov.: proposal of Ralstonia pickettii (Ralston, Palleroni and Doudoroff 1973) comb. nov., Ralstonia solanacearum (Smith 1896) comb. nov. and Ralstonia eutropha (Davis 1969) comb. nov. Microbiology and Immunology 39:897-904.

YADESSA, G.B.; VAN BRUGGEN, A.H.C. \& OCHO, F.L. 2010. Effects of different soil amendments on bacterial wilt caused by Ralstonia solanacearum and on the yield of tomato. Journal of Plant Pathology 92:439-450.

YAMADA, T.; KAWASAKI, T.; NAGATA, S.; FUJIWARA, A.; USAMI, S. \& FUJIE, M. 2007. New bacteriophages that infect the phytopathogen Ralstonia solanacearum. Microbiology 153:2630-2639.

YAMAMOTO, S.; SHIRAISHI, S.; KAWAGOE, Y.; MOCHIZUKI, M. \& SUZUKI, S. 2015. Impact of Bacillus amyloliquefaciens S13 - 3 on control of bacterial wilt and powdery mildew in tomato. Pest Management Science 71:722-727.

YAO, J. \& ALLEN, C. 2007. The plant pathogen Ralstonia solanacearum needs aerotaxis for normal biofilm formation and interactions with its tomato host. Journal of Bacteriology 189:6415-6424.

ZHANG, Y. \& QIU, S. 2016. Phylogenomic analysis of the genus Ralstonia based on 686 single-copy genes. Antonie van Leeuwenhoek 109:71-82. 
ZHAO, Y.; ZHANG, C.; CHEN, H.; YUAN, M.; NIPPER, R.; PRAKASH, C.S.; ZHUANG, W. \& HE, G. 2016. QTL mapping for bacterial wilt resistance in peanut (Arachis hypogaea L.). Molecular Breeding 36:1-11. 


\section{CAPÍTULO 2}

SISTEMA PARA IDENTIFICAÇÃO DE BIOVARES VIA PCR EMPREGANDO INICIADORES ESPECÍFICOS DERIVADOS DA ANÁLISE GENÔMICA COMPARATIVA DE ISOLADOS DO COMPLEXO DE ESPÉCIES DE Ralstonia 


\section{Sistema para identificação de biovares via PCR empregando iniciadores específicos derivados da}

análise genômica comparativa de isolados do Complexo de Espécies de Ralstonia

\section{RESUMO}

O complexo de espécies de Ralstonia (recentemente subdividido em três espécies, $R$. solanacearum, $R$. pseudosolanacearum e $R$ syzygii) apresenta grande diversidade, com variadas subdivisões infraespecíficas, como raças, biovares, filotipos e sequevares. A classificação em biovares tem se mostrado útil na seleção de isolados para uso em sistemas de avaliação de germoplasma dentro dos programas de melhoramento genético do tomateiro e de distintas plantas hospedeiras. Atualmente as cinco biovares existentes são determinadas por testes em meio de cultura. Visando agilizar e simplificar o processo, o objetivo desse capítulo foi desenvolver um sistema de marcadores para cada biovar, utilizando primers específicos que foram derivados da informação de sequência de marcadores RAPD. A estratégia de bulk segregant analysis permitiu a identificação de marcadores do tipo biovar-específicos para um conjunto de biovares presentes no Brasil. Dez isolados por biovar foram agrupados nos "bulks" para as análises com o sistema de marcadores RAPD. Uma coleção de 340 primers RAPD foi utilizada e 11 mostraram polimorfismos com potencial valor diagnóstico. Desses, quatro primers que geraram marcadores estáveis foram selecionados (OP-A7, OP-I18, OP-J1 e OPK10). A informação de sequência destes amplicons polimórficos foi utilizada para o desenho de seis primers do tipo SCAR (Sequence Characterized Amplified Region)(J1-B1-B, SCARi18-B2A, SCAR-A7-B3, A7-B3, SCAR-K10-B3, K10-B3). Além disso, a estratégia de subtração in silico associada a um conjunto de genomas completos de $R$. pseudosolanacearum permitiu o desenho de primers específicos para a região do gene polS (codificador da sorbitol desidrogenase), que geraram marcadores exclusivos para isolados de $R$. pseudosolanacearum. Esse conjunto de primers apresentou potencial para identificação das biovares 1 (J1-B1-B-274 
pb) e 2A (SCAR-i18-B2A). Para a biovar 2T nenhum dos primers avaliados apresentou especificidade.

Palavras-chave: primers, iniciadores específicos, biovar, murcha bacteriana. 


\title{
A biovar-specific identification system based on PCR employing primers derived from comparative genomic analysis of isolates from the Ralstonia species complex
}

\begin{abstract}
The Ralstonia solanacearum species complex (recently subdivided into three species, $R$. solanacearum, $R$. pseudosolanacearum, and $R$ syzygii) displays a large diversity, with infraspecific subdivisions such as races, biovars, phylotypes, and sequevars. The classification in biovars has been useful for the selection of isolates for use in germplasm evaluation systems within breeding programs of tomatoes and other species. Currently, the five biovars are determined by tests on culture media, which are cumbersome and time-consuming. The objective of this chapter was to develop a biovar-specific molecular marker system aiming to simplify the diagnostic process. Ten isolates of each biovar were grouped in bulks for the RAPD markers screening. A collection of 340 RAPD primers was used and 11 primers revealed polymorphisms and therefore showed potential diagnostic value of biovars. From those, four primers (OP-A7, OP-i18, OP-J1, OP-K10) generated stable markers and were selected for further analyses. The information derived from sequencing a subgroup of polymorphic RAPD amplicons was initially used to generate biovar-specific primers. The sequence information of these polymorphic amplicons was used for the design of seven SCAR primers (J1-B1-B, SCAR-i18-B2A, SCAR-A7-B3, A7-B3, SCAR-K10-B3, and K10-B3). In addition, an in silico subtraction strategy using genomic information from a set of complete genome sequences of $R$. pseudosolanacearum allowed the design of pols (sorbitol dehydrogenase) specific primers, which generated specific markers for $R$. pseudosolanacearum isolates. The set of primers displayed potential for identification of biovar 1 (J1-B1-B-274 pb) and biovar 2A (SCAR-i18B2A) isolates. However, for biovar 2T none of the evaluated primers displayed specificity.
\end{abstract}

Keywords: primers, molecular marker system, biovar, diagnostic, bacterial wilt. 


\section{INTRODUÇÃO}

O complexo de espécies de Ralstonia (CER) representa um grupo cosmopolita de patógenos de solo bastante diversificado e adaptado a uma ampla gama de plantas hospedeiras (Hayward, 1994a; Fegan \& Prior, 2005). A diversidade fenotípica de isolados do CER foi inicialmente catalogada utilizando critérios de círculo de hospedeiras ou raças (Buddenhagen et al., 1962) e bioquímicos (= biovares) (Hayward, 1964). O sistema de biovares descrimina variantes do CER de acordo com a capacidade dos diferentes isolados de produzir gás a partir de nitrato e de oxidar um conjunto de dissacarídeos (maltose, lactose e celobiose) e de alcoóis (manitol, dulcitol e sorbitol) (Hayward, 1991; Hayward, 1994b). Em termos mundiais, seis biovares foram identificadas até o presente momento (Horita \& Tsuchiya, 2001; Wicker et al., 2007), sendo que algumas apresentam distribuição cosmopolita e outras apresentam distribuição geográfica e/ou ecológica mais restrita (Hayward, 1994a; Hayward, 1994b).

O ensaio de determinação de biovares foi inicialmente empregado como um teste adicional de laboratório visando agrupar isolados de $R$. solanacearum (Hayward, 1994a; Hayward, 1994b). Embora de execução laboratorial demorada, onerosa e trabalhosa, o sistema de classificação de biovares tem se mostrado muito informativo no ponto de vista prático, revelando associações com características peculiares dos diferentes isolados, tais como padrões de proteínas de membrana, nichos ecológicos, gama de plantas hospedeiras e distribuição geográfica (Dristig \& Dianese, 1990; Prior et al., 1990; Hayward, 1994b; Lopes et al., 1994; Netto et al., 2003).

No Brasil, o sistema de classificação de biovares tem se mostrado igualmente informativo, revelando interessantes correlações/associações com aspectos ecológicos, gama de plantas hospedeiras e perfil de virulência. Por exemplo, isolados de raça 1/biovar 1 apresentam maior incidência e severidade em tomateiro (Solanum lycopersicum L.) (Takatsu \& Lopes, 1997), além disso, isolados da biovar 1 têm a maior gama de hospedeiras entre todas as 
seis biovares caracterizadas (Norman et al., 2009). Outra característica dos isolados da raça 1/biovar 1 é o fato de eles englobarem, de maneira majoritária, o grupo de isolados nativos dos solos do 'Cerrado' brasileiro (Lopes, 2005).

Por sua vez, os isolados da raça 3/biovar 2A estão associados à capacidade de causar murcha em temperaturas mais amenas $\left(25^{\circ} \mathrm{C}\right)$ quando comparados com isolados da biovar $2 \mathrm{~T}$, que predominam em regiões mais quentes (Lopes, 2005). As gamas de hospedeiras de isolados das biovares $2 \mathrm{~A}$ e $2 \mathrm{~T}$ também divergem. Isolados da biovar $2 \mathrm{~T}$ têm sido obtidos de berinjela e de eucalipto que, no entanto, não são hospedeiras comumente infectadas por isolados da biovar 2A (Marques et al., 2012; Santana et al., 2012). A biovar 2A tem sido empregada como o principal do agente de bioterrorismo, tendo diversos marcadores moleculares disponíveis para identificação desses isolados (Fegan et al., 1998; Stulberg et al., 2015). Isolados da biovar 2T foram registrados pela primeira vez fora do seu provável centro de origem (Brasil), sendo relatado no Irã (Nouri et al., 2009)

Isolados da raça 1/biovar 3 (atualmente $R$. pseudosolanacearum) apresentam maior virulência em espécies do gênero Capsicum (Lopes \& Boiteux, 2004). Além disso, resultados recentes indicam que, em condições experimentais, acessos de cafeeiro (Coffea arabica L.) são afetados por isolados da biovar 3, mas não por isolados da biovar 1 (Lopes et al., 2015). A biovar 3, no Brasil, representa uma introdução de um filotipo exótico (filotipo I), uma vez que isolados dessa biovar têm como provável origem geográfica o continente asiático. Somado a isso, a baixa diversidade detectada nos isolados de biovar 3 obtidos no Brasil, indica uma introdução relativamente recente desta variante do patógeno no país (Santiago et al., 2016).

A ocorrência de isolados da biovar 4 (R. pseudosolanacearum) não foi ainda registrada no Brasil. Isolados dessa biovar se caracterizam por serem patogênicos ao gengibre (Zingiber officinale Roscoe) (Hayward, 1994a). Em um levantamento realizado no Japão, somente 
isolados das biovares 3 e 4 foram detectados, sendo caracterizados como pertencentes ao filotipo I (R. pseudosolanacearum). O tomateiro, a berinjela, o pimentão, a batata, a abóbora e o pepino estão entre as principais hospedeiras de isolados da biovar 3 (Horita \& Tsuchiya, 2001). Os isolados da biovar 5 são os principais causadores de murcha bacteriana em amoreira e outras espécies arbóreas do gênero Morus (Urticales: Moraceae). Isolados dessa biovar apresentam um perfil distinto de utilização de carboidratos (He et al., 1983). Isolados de biovares 3 e 4 também podem causar murcha em amoreira, porém apresentam importância secundária quando comparados aos isolados da biovar 5 (Pan et al., 2013).

Devido à diversidade presente no CER, o sistema binário de diferenciação de isolados, que persistiu sendo empregado por mais de três décadas, tem se mostrado insuficiente para explicar e catalogar de maneira adequada a diversidade presente em isolados do CER (Hayward, 1994a; Horita et al., 2014). Para aumentar os conhecimentos sobre a diversidade de isolados do CER, foram propostos outros sistemas de divisão do grupo, envolvendo a utilização de características fenotípicas e genotípicas (Fegan \& Prior, 2005). No entanto, tais sistemas com amplas divisões descrevem a diversidade da bactéria, sem que necessariamente apresentem utilidades práticas para outros temas de pesquisa, como, por exemplo, o do controle de doenças.

A determinação dos chamados 'filotipos' representa um dos novos critérios de classificação do CER ao nível infraespecífico. Esse sistema incorpora as informações derivadas de marcadores moleculares obtidos por meio de um conjunto de iniciadores em PCR multiplex que amplificam a região intergênica 16S-23S ribossomal (Seal et al., 1993; Fegan \& Prior, 2005). Esse sistema, em combinação com a informação obtida de sequências do gene codificador da endoglucanase ( $e g l$ ) e de um segmento do gene que codifica a proteína de reparo de DNA (MutS), permitiu, até o presente momento, a definição de 57 variantes, denominadas de 'sequevares' (Fegan \& Prior, 2005). No entanto, Wicker et al. (2012) ressaltam uma importante limitação do atual sistema de determinação de filotipos e apontam a necessidade de 
empregar outros genes visando uma caracterização mais adequada dos isolados. Um dos principais argumentos é o fato de que gene codificador da endoglucanase apresenta taxas de recombinação mais altas que outros genes [por exemplo os do tipo housekeeping tais como o hrp (hipersenstive response and pathogenesis)] o que dificulta seu emprego em estudos de diversidade e de inferências filogenéticas (Wicker et al., 2012).

O sistema de marcadores RAPD ( $\underline{\text { Randomly }}$ Amplified $\underline{\text { Polymorphic }} \underline{\mathrm{D}} \mathrm{NA})$ apresenta uma série de vantagens para estudos de diversidade genética que incluem simplicidade de execução e reduzido aporte tecnológico. Além disso, esse sistema não necessita de conhecimento prévio da sequência ou do genoma em estudo (Williams et al., 1990). O sistema de marcadores RAPD foi previamente utilizado em estudos de diversidade do CER gerando os marcadores específicos para isolados da raça 3/biovar 2 (Opina et al., 1997). No entanto, foram relatados casos de inespecificidade, com amplificações também observadas em um subgrupo de isolados de $R$. syzygii e de Blood disease (Opina et al., 1997). O sistema RAPD se mostrou uma ferramenta bastante útil em estudos de diversidade de populações de isolados de $R$. solanacearum obtidos em tomateiro em Taiwan quando comparado ao tradicional sistema REP-PCR (Jaunet \& Wang, 1999). Em outro estudo, Lee \& Wang (2000) desenvolveram primers para detecção de isolados do CER em solo a partir da informação obtida após clonagem e análise de sequência de amplicons RAPD.

A instabilidade do perfil de amplicons é um dos problemas associados com o sistema RAPD. Para minimizar esse problema, o desenho de primers específicos a partir da informação de sequência de amplicons RAPD tem sido empregado (Paran \& Michelmore, 1993). Esta estratégia gera uma nova classe de marcadores denominados de SCAR (Sequence

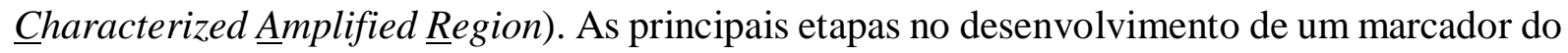
tipo SCAR envolvem a identificação de um iniciador que confere polimorfismo entre genótipos contrastantes para uma dada característica de interesse, seguido do isolamento e da clonagem 
do amplicon polimórfico em um vetor bacteriano (plasmídeo). O fragmento polimórfico é então caracterizado via sequenciamento. Na etapa seguinte, iniciadores de tamanho maiores (entre 16 e 24 pares de bases), que incluem os decâmeros usados no sistema RAPD, são sintetizados e posteriormente validados para confirmar a manutenção dos polimorfismos (Paran \& Michelmore, 1993). A estratégia de SCAR tem sido empregada para gerar marcadores úteis para estimar diversidade genética de fitopatógenos bacterianos (Lim et al., 2009), incluindo isolados indianos do CER (Gund et al., 2011; Gund et al., 2013). No entanto, de acordo com o nosso conhecimento, essa estratégia não foi ainda empregada para desenvolver marcadores ligados a determinação das diferentes biovares do CER.

Uma estratégia, denominada de bulked segregant analysis (BSA), tem sido empregada para intensificar a identificação de polimorfismos entre grupos de genótipos contrastantes (Michelmore et al., 1991). Nessa estratégia, são criados grupos (bulks) de genótipos que compartilham um determinado fenótipo e que são então analisados geneticamente por meio de diferentes sistemas de marcadores. O emprego da estratégia de BSA foi indicado para aumentar a escala do processo de identificação polimorfismos e de potenciais marcadores moleculares, uma vez que a genotipagem de um grande número de amostras individuais tem um maior custo e demanda um tempo maior de execução (Quarrie et al., 1999).

A metodologia BSA é frequentemente utilizada no melhoramento genético para identificar marcadores associados com fenótipos contrastantes (Xu et al., 2016), incluindo fatores de resistência a $R$. solanacearum em diversas hospedeiras [para revisão ver Huet (2014)]. Na caracterização de microrganismos, a estratégia de BSA tem sido utilizada com sucesso na levedura Saccharomyces cerevisiae em combinação com sequenciamento em larga escala (Wenger et al., 2010). No entanto, a estratégia BSA ainda não foi empregada para identificar marcadores moleculares associados com as biovares do CER. 
A recente disponibilidade de genomas completos de isolados do CER tem permitido o alinhamento in silico de diferentes isolados e a identificação de regiões polimórficas com potencial utilização em sistemas de marcadores para distinguir diferentes fenótipos ou grupos taxonômicos dentro da espécie. A comparação dos genomas dos isolados GMI1000 (raça 1/biovar 3) e UW551 (raça 3/biovar 2) revelou uma região de $22 \mathrm{~Kb}$ que distingue biovares 3 e 4 das biovares 1 e 2 (Gabriel et al., 2006). A estratégia denominada de subtração in silico foi também utilizada por Stulberg et al. (2015) resultando em um conjunto de primers específicos para o CER, nomeados de RsSC, e outros específicos para o agente de bioterrorismo, raça 3/biovar 2A (RsSA) e que também consegue amplificar segmentos genômicos de alguns isolados $2 \mathrm{~T}$ (sequevar 2).

Diante da utilidade prática do sistema de caracterização de biovares no estudo da diversidade de isolados do CER, existe a demanda por um teste mais rápido e preciso na determinação destas variantes bacterianas. Neste contexto, o presente trabalho buscou associar marcadores moleculares com quatro diferentes biovares de ocorrência no território brasileiro, utilizando a técnica de BSA combinada com o uso do sistema de marcadores RAPD, sendo os amplicons polimórficos posteriormente convertidos em marcadores do tipo SCAR. Foram também desenvolvidos primers específicos gerados por análise via subtração in silico dos genomas alinhados das distintas biovares atualmente disponíveis no GenBank e em outras bases de dados. Genes com potencial envolvimento em enzimas associadas com os testes bioquímicos de distinguem as diferentes biovares foram utilizados como alvos iniciais nesta análise.

\subsection{Objetivo Geral}

Diante da utilidade do sistema de caracterização de biovares no estudo da diversidade do CER, existe a demanda por um teste rápido e preciso na sua determinação. Desta forma, o presente trabalho teve como objetivo o desenvolvimento de um sistema molecular para 
identificação de biovares usando primers específicos para cada uma das quatro biovares presentes no Brasil (1, 2A, 2T e 3).

\subsection{Objetivos específicos}

1. Empregar a combinação do sistema de marcadores RAPD e a estratégia de Bulked segregant analysis (BSA) para buscar polimorfismos entre pools genômicos compostos por isolados representativos da diversidade presente em cada uma das quatro biovares do CER relatadas no Brasil (1, 2A, 2T e 3);

2. Sequenciar amplicons gerados pelo sistema de marcadores RAPD que se mostraram polimórficos e/ou exclusivos nas populações de cada biovar visando o desenvolvimento de marcadores do tipo SCAR;

3. Analisar a informação genética/genômica disponível para um conjunto de genes com potencial envolvimento em enzimas associadas com os testes bioquímicos que distinguem as diferentes biovares do CER, visando empregar essa informação no desenvolvimento de marcadores para distinção destes variantes bioquímicos;

4. Desenvolver um conjunto de primers específicos gerados pela combinação de análises obtidas via sistemas de marcadores moleculares e subtração in silico dos genomas alinhados das diversas biovares do CER disponíveis no GenBank e em outras bases de dados;

5. Desenvolver e validar esse conjunto de primers dentro de sistemas robustos de identificação da diferentes biovares do CER via PCR.

\section{MATERIAL E MÉTODOS}

\subsection{Seleção dos isolados para estabelecimento de bulks contrastantes para as} diferentes biovares

No estabelecimento de bulks contrastantes, dez isolados de cada uma das biovares presentes no Brasil (1, 2A, 2T e 3) foram selecionados da coleção de isolados do CER da Embrapa Hortaliças. Originalmente armazenados em tubos de criogenia de $5 \mathrm{~mL}$ com água 
mineral, armazenados em temperatura ambiente. Visando englobar de maneira mais ampla a diversidade presente no Brasil, os isolados de cada biovar foram selecionados de distintos locais de coleta e de distintas plantas hospedeiras (Figura 7). Os isolados selecionados foram cultivados em meio CPG (Kelman, 1954), mantidos em câmara de crescimento por 48 horas a $28^{\circ} \mathrm{C}$. Colônias típicas foram então repicadas. Após mais 48 horas nas mesmas condições, as placas foram raspadas e centrifugadas em microtubos de $2 \mathrm{~mL}$ e congeladas com água Milli-Q até o momento da extração de DNA. A extração de DNA seguiu o protocolo de Mahuku (2004) com modificações. As colônias descongeladas foram centrifugadas por 15 min a 10000 rpm para o descarte da água e, em seguida foi adicionado $200 \mu \mathrm{L}$ de Tris EDTA (Tris $10 \mathrm{mM}$, EDTA $1 \mathrm{mM}), 30 \mu \mathrm{L}$ de SDS (20\%) e $10 \mu \mathrm{L}$ de Proteinase K (0,02 g/mL), com homogeneização por meio de um vortex e 40 min em banho maria. Foram adicionados $250 \mu \mathrm{L}$ de acetato de amônio 7,5 M, com nova homogeneização vortex e manutenção à $-20^{\circ} \mathrm{C}$ por $10 \mathrm{~min}$. A suspensão foi centrifugada por 20 min a $13000 \mathrm{rpm}$ e o sobrenadante $(\sim 400 \mu \mathrm{L})$ foi transferido para um novo tubo. $\mathrm{O}$ mesmo volume de isopropanol foi adicionado e o tubo foi incubado à $-20^{\circ} \mathrm{C}$ por 1 a 2 horas. Em seguida, a preparação foi centrifugada por 20 minutos a 13000 rpm e o sobrenadante descartado. O pellet foi então lavado com $800 \mu \mathrm{L}$ de etanol 70\%. Após descarte do etanol, o pellet foi seco e posteriormente hidratado com água Milli-Q e armazenado à $-20^{\circ} \mathrm{C}$. 


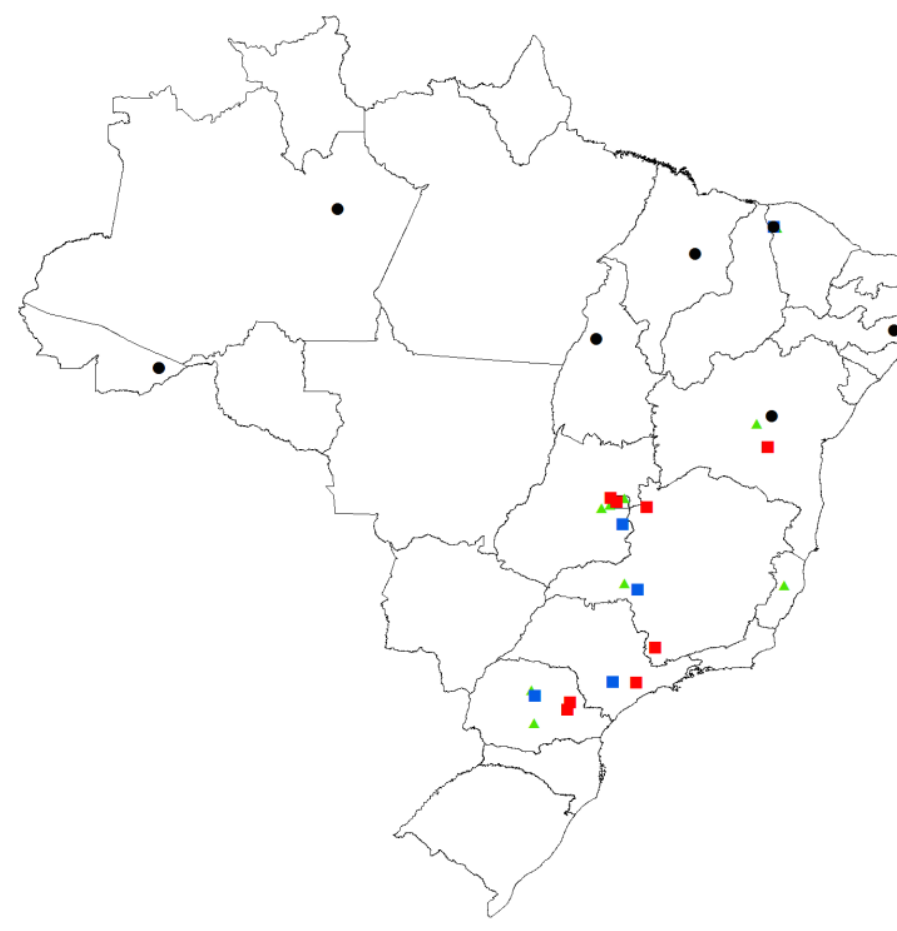

\begin{tabular}{|c|c|c|c|c|c|}
\hline & Isolado & Hospedeira & Local & Estado & Ano \\
\hline \multirow{10}{*}{ 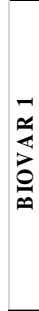 } & RS 433 & Batata & Santa Juliana & MG & 2010 \\
\hline & RS 436 & Tomate & Seabra-BA & $\mathrm{BA}$ & 2011 \\
\hline & RS 450 & Batata & Guarapuava & PR & 2011 \\
\hline & RS 460 & Tomate & Borrazópolis & PR & 2011 \\
\hline & RS 501 & Tomate & Ubiapina & $\mathrm{CE}$ & 2012 \\
\hline & RS 517 & Tomate & $\mathrm{CNPH}$ & DF & 2013 \\
\hline & RS518 & Tomate & Alexânia & GO & 2013 \\
\hline & RS 533 & Tomate & Marilândia & ES & 2013 \\
\hline & RS 536 & Tomate & Taquara & DF & 2013 \\
\hline & K60 & Tomate & EUA & & 1954 \\
\hline \multirow{10}{*}{$\frac{\sqrt{3}}{\approx}$} & RS 12 & Batata & Itapetininga & SP & 1987 \\
\hline & RS 23 & Batata & Ibicoara & BA & 1988 \\
\hline & RS 26 & Batata & Castro & PR & 1988 \\
\hline & RS 429 & Batata & Araxá & MG & 2010 \\
\hline & RS 461 & Batata & Ibicoara & $\mathrm{BA}$ & 2011 \\
\hline & RS 488 & Tomate & Grandes Rios & PR & 2012 \\
\hline & RS 498 & Batata & Araxá & MG & 2012 \\
\hline & RS 506 & Berinjela & Ubajara & $\mathrm{CE}$ & 2012 \\
\hline & RS 534 & Tomate & Cristalina & $\mathrm{GO}$ & 2013 \\
\hline & RS 537 & Batata & Itapetininga & SP & 2013 \\
\hline \multirow{10}{*}{ 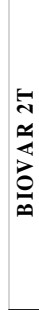 } & RS 44 & Batata & PAD-DF & $\mathrm{DF}$ & 1989 \\
\hline & RS 59 & Batata & Castro & PR & 1990 \\
\hline & RS 66 & Batata & Ibicoara & BA & 1990 \\
\hline & RS 71 & Berinjela & Brazlândia & $\mathrm{DF}$ & 1990 \\
\hline & RS 77 & Berinjela & $\mathrm{CNPH}$ & DF & 1991 \\
\hline & RS 94 & Batata & Pirai do Sul & PR & 1992 \\
\hline & RS 478 & Gerânio & Vargem Grande Paulista & SP & 2002 \\
\hline & RS 481 & Eucalipto & Alexânia & $\mathrm{GO}$ & 2009 \\
\hline & RS 482 & Eucalipto & Alexânia & $\mathrm{GO}$ & 2009 \\
\hline & RS 546 & Tomate & Ipuiuna & MG & 2014 \\
\hline \multirow{10}{*}{ 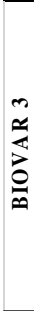 } & RS 18 & Tomate & Manaus & $\mathrm{AM}$ & 1987 \\
\hline & RS 355 & Jiló & Cólmeia & TO & 2008 \\
\hline & RS 380 & Pimentão & Camocin de são Felix & $\mathrm{PE}$ & 2008 \\
\hline & RS 388 & Pimenta & Rio Branco & $\mathrm{AC}$ & 2009 \\
\hline & RS 391 & Tomate & Rio Branco & $\mathrm{AC}$ & 2009 \\
\hline & RS 474 & Tomate & Dom Pedro & MA & 2011 \\
\hline & RS 507 & Berinjela & Ubajara & $\mathrm{CE}$ & 2012 \\
\hline & RS 508 & Tomate & Utinga & BA & 2013 \\
\hline & GMI1000 & Tomate & Guyana Francesa & - & 1978 \\
\hline & UW363 & Tomate & China & - & 1980 \\
\hline
\end{tabular}

Figura 7. Distribuição dos isolados brasileiros do complexo de espécies de Ralstonia que formaram os bulks contrastantes para as biovares 1, 2A, 2T e 3. Os triângulos verdes indicam os locais de coleta dos isolados da biovar 1, quadrados vermelhos da biovar $2 \mathrm{~A}$, quadrados azuis da biovar $2 \mathrm{~T}$ e círculos pretos indicam isolados da biovar 3. Lista da classificação de biovar, hospedeira original, local e ano de isolamento do conjunto de isolados do complexo de espécies de Ralstonia utilizado no estabelecimento dos bulks contrastantes para as distintas biovares e que foram analisados via Bulked segregant analysis (BSA). 


\subsection{Uso do sistema de marcadores RAPD}

Para o estabelecimento dos bulks, o DNA genômico de dez isolados de cada biovar foi quantificado, utilizando o espectrofotômetro NanoDrop ${ }^{\circledR}$ Lite $\quad$ (NanoDrop Lite Spectrophotometer, The Thermo Scientific, Wilmington-DE, EUA) e diluído até a concentração de $100 \mathrm{ng} / \mu \mathrm{L}$. Volumes de $100 \mu \mathrm{L}$ de DNA de cada isolado foram adicionados em um microtubo de 1,5 mL e vortexados brevemente. Os quatro bulks de isolados das biovares contrastantes foram avaliados com 340 primers RAPD (série Operon OPA-01 até OPZ-20, Operon Technologies, Alameda, Califórnia, EUA). A reação foi composta de $1 \mu \mathrm{L}$ de DNA genômico (100 ng/ $\mu \mathrm{L}), 1,25 \mu \mathrm{L}$ de tampão 10X (100 mM Tris-HCl, 500 mM KCl, pH 8.3), 0,6 $\mu \mathrm{L}$ de $\mathrm{MgCl}_{2}(50 \mathrm{mM}), 0,5 \mu \mathrm{L}$ de dNTPs $(2,5 \mathrm{mM}$ cada), 0,2 $\mu \mathrm{L}$ de Taq DNA polimerase (5u/ $\mu \mathrm{L}), 2 \mu \mathrm{L}$ de primer, $6,95 \mu \mathrm{L}$ de $\mathrm{H}_{2} \mathrm{O}$ Milli-Q com volume total de 12,5 $\mu \mathrm{L}$. As reações de amplificação foram efetuadas em um termociclador Veriti ${ }^{\circledR}$ Thermal Cycler. O programa utilizado para a amplificação dos fragmentos foi de um ciclo de $94^{\circ} \mathrm{C}$ por 2 minutos, seguido de 35 ciclos de $94^{\circ} \mathrm{C}$ por 30 segundos, para desnaturação, $36^{\circ} \mathrm{C}$ por 1 minuto para anelamento, e $72^{\circ} \mathrm{C}$ por 2 minutos para extensão, o ciclo final constituiu-se de $68^{\circ} \mathrm{C}$ por 10 minutos. Os produtos da PCR foram analisados em géis de agarose (1,5\%) corados com brometo de etídio e visualizados sob luz ultravioleta, utilizando-se o marcador 1 Kb Plus DNA Ladder ${ }^{\circledR}$ (Invitrogen) para a análise dos produtos. Após a seleção dos primers RAPD que apresentaram padrões de amplicons polimórficos, a reação foi repetida, dessa vez, com bulks abertos, ou seja, o DNA de cada isolado foi avaliado individualmente para cada primer RAPD, visando validar os marcadores obtidos. Para essa avaliação via RAPD, foi usado o mesmo protocolo descrito anteriormente. Os amplicons que se mostraram estáveis, isto é, confirmaram o resultado anterior dos bulks, foram cortados do gel de agarose usando um bisturi, transferidos para microtubos de $1,5 \mathrm{~mL}$ e purificados com o kit Wizard ${ }^{\circledR}$ SV Gel and PCR Clean-Up System ${ }^{\circledR}$. A 
purificação foi quantificada em um espectrofotômetro NanoDrop ${ }^{\circledR}$ Lite e preparados para a clonagem.

\subsection{Clonagem e Sequenciamento}

Para a clonagem dos amplicons foi usado o protocolo do TOPO TA Cloning Kit (Invitrogen). A ligação foi feita adicionando a microtubos: $1 \mu \mathrm{L}$ do vetor TOPO (10 ng)1 $\mu \mathrm{L}$ de solução salina; $3 \mu \mathrm{L}$ de água Milli-Q e $1 \mu \mathrm{L}$ do produto de PCR ( $\approx 30$ ng), com volume total de $6 \mu \mathrm{L}$ de ligação. As reações foram incubadas por 30 minutos em temperatura ambiente. Após esse período foram adicionados $2 \mu \mathrm{L}$ da reação de ligação em cada tubo de célula competente E. coli (Mach1-T1), incubando-os em gelo por 10 minutos. O choque térmico foi dado retirando os tubos do gelo e colocando em banho-maria a exatamente $42^{\circ} \mathrm{C}$ por 30 segundos. Imediatamente os tubos foram retirados e acondicionados em gelo por 2 minutos. Foram adicionados $250 \mu \mathrm{L}$ de meio SOC e as transformações foram incubadas durante 1 hora a $37^{\circ} \mathrm{C}$, com agitação dos tubos em mesa agitadora orbital a $200 \mathrm{rpm}$. Um volume de $100 \mu \mathrm{L}$ de cada suspensão de bactérias foi distribuído em placas de Petri contendo meio LB + ampicilina (50 $\mu \mathrm{g} / \mathrm{mL}$ ). As placas foram incubadas em estufa a $37^{\circ} \mathrm{C}$ overnight. A confirmação e seleção das bactérias transformadas foram feitas via PCR com anelamento a $37^{\circ} \mathrm{C}$ usando os primers universais do vetor M13 Forward (5'CGC-CAG-GGT-TTT-CCC-AGT-CAC-GAC3') e Reverse (5'TCA-CAC-AGG-AAA-CAG-CTA-TGA-C3'). As bactérias apresentando os fragmentos do tamanho esperado tiveram as reações de PCR purificadas para o posterior sequenciamento. Os fragmentos foram sequenciados em um sequenciador ABI PRISM 3100 da Embrapa Hortaliças, utilizando o Kit ABI Prism BigDye version 3.1 (Applied Biosystems do Brasil) e os iniciadores universais de síntese do vetor M13 (M13 “reverse" e "forward"). 
2.4. Análise de sequências dos amplicons RAPD polimórficos e desenho de primers SCARs

Os segmentos sequenciados correspondentes aos amplicons RAPDs foram utilizados para o desenho de primers SCARs de 15 a 20 pares de bases. Esses primers que consistiram da sequência do próprio primer RAPD original mais um segmento de bases internas ao primer (Paran \& Michelmore, 1993). Primers do tipo SCAR foram desenhados usando as informações de sequência amplicons RAPD polimórficos. Nessa análise foi também considerada a posição do fragmento RAPD sequenciado no genoma de $R$. solanacearum e o alinhamento das várias biovares. Desta forma, primers internos à região de anelamento também foram desenhados quando observados polimorfismos internos entre biovares. Estes primers internos foram combinados entre si e também com os SCARS.

\subsection{Análise de sequência, identificação de regiões com identidade e localização física}

\section{dos marcadores RAPD e SCAR polimórficos}

Trinta e quatro (34) genomas de $R$. solanacearum foram extraídos da base de dados do GenBank e as biovares e filotipos correspondentes foram buscados na literatura (Tabela 7). Segmentos genômicos correspondentes aos RAPDs clonados e sequenciados foram identificados em um alinhamento com os 34 genomas disponíveis do CER. As sequências resultantes dos primers "forward" e "reverse" obtidas via sequenciamento foram montadas para formar um contig. Correções foram realizadas visualmente considerando a informação do eletroferograma com o auxílio do programa Geneious R8 (Kearse et al., 2012) e confirmadas quanto sua etiologia pelo BLAST (Madden et al., 1996). A análise de polimorfismos foi feita visualmente nas sequências alinhadas, buscando regiões exclusivas para uma determinada biovar, com potencial para serem usadas como marcador informativo para distinguir as diferentes biovares. 
Tabela 7. Lista dos isolados do complexo de espécies de Ralstonia com genomas completos disponíveis na base de dados do GenBank e EMBL que foram utilizados em análises via subtração in silico em busca de regiões exclusivas para as diferentes biovares.

\begin{tabular}{|c|c|c|c|c|c|}
\hline Isolado & $\begin{array}{l}\text { Filotipo/ } \\
\text { sequevar }\end{array}$ & Biovar & Hospedeira & Origem & Acesso \\
\hline FJAT-1458-avir & 1 & - & $\begin{array}{l}\text { Tomate } \\
\text { Assintomático }\end{array}$ & China & GenBank: AHIX00000000.1 \\
\hline FJAT-91 & 1 & 3 & Tomate & China & GenBank: AHIY00000000 \\
\hline FQY_4 & I & 3 & Solo & China & GenBank: СР004012, СР004013 \\
\hline Rs-09-161 & I & 3 & Berinjela & Índia & $\begin{array}{l}\text { GenBank: NZ_CM002757.1, } \\
\text { NZ_CM002758.1 }\end{array}$ \\
\hline Rs-10-244 & I & 3 & Pimenta & Índia & $\begin{array}{l}\text { GenBank: NZ_CM002755.1, } \\
\text { NZ_CM002756.1 }\end{array}$ \\
\hline Y45 & I & 3 & Fumo & China & GenBank: AFWL00000000 \\
\hline SD54 & $\mathrm{I}-16$ & 4 & Gengibre & China & GenBank: ASQR00000000.2 \\
\hline GMI1000 & $\mathrm{I}-18$ & 3 & Tomate & $\begin{array}{l}\text { Guiana } \\
\text { Francesa }\end{array}$ & $\begin{array}{ll}\text { GenBank: } & \text { NC_003295, } \\
\text { NC_003296 } & \end{array}$ \\
\hline NCPPB 282 & II- 2 & 2 & Batata & Colômbia & GenBank: JQSH00000000.1 \\
\hline 23-10BR & II-27 & 2 & Batata & Brasil & GenBank: JQOI00000000.1 \\
\hline P673 & II-4 & 1 & $\begin{array}{l}\text { Epipremnum } \\
\text { aureum }\end{array}$ & Estados Unidos & GenBank: JALO01000000 \\
\hline B50 & IIA-24 & 1 & Banana & Brasil & EMBL: PRJEB7421 \\
\hline IBSBF1900 & IIA-24 & 1 & Banana & Brasil & EMBL: PRJEB8309 \\
\hline CFBP2957 & IIA-36 & 1 & Tomate & $\begin{array}{l}\text { Antilhas } \\
\text { Francesas }\end{array}$ & EMBL: FP885897, FP885907 \\
\hline Grenada 9-1 & IIA-6 & 1 & Banana & Granada & EMBL: PRJEB7428 \\
\hline UW181 & IIA-6 & 1 & Banana da Terra & Venezuela & EMBL: PRJEB8309 \\
\hline K60T & IIA-7 & 1 & Tomate & Estados Unidos & EMBL: CAGT01000001 \\
\hline CFIA906 & IIB & 2 & - & - & GenBank: JNVP00000000.3 \\
\hline CFBP3858 & IIB-1 & 2 & Batata & Holanda & EMBL: PRJEB8309 \\
\hline IPO1609 & IIB-1 & 2 & Batata & Holanda & GenBank: CU914168, CU914166 \\
\hline NCPPB909 & IIB-1 & 2 & - & Egito & GenBank: JNGD00000000.1 \\
\hline POPS2 & IIB-1 & 2 & - & China & GenBank: JQSI00000000.1 \\
\hline RS2 & IIB-1 & 2 & Batata & Bolívia & EMBL: PRJEB8309 \\
\hline UY031 & IIB-1 & 2 & Batata & Uruguai & $\begin{array}{l}\text { GenBank: NZ_CP012687.1, } \\
\text { NZ_CP012688.1 }\end{array}$ \\
\hline CFBP1416 & IIB-3 & 1 & Banana da Terra & Costa Rica & EMBL: PRJEB7434 \\
\hline CIP417 & IIB-3 & 1 & Banana & Filipinas & EMBL: PRJEB7427 \\
\hline MolK2 & IIB-3 & 1 & Banana & Filipinas & GenBank: CAHW01000040 \\
\hline
\end{tabular}




\begin{tabular}{lcclll}
\hline CFBP6783 & IIB-4 & 1 & Helicônia & Antilhas & EMBL: PRJEB7432 \\
IBSBF1503 & IIB-4 & 1 & Pepino & Brancesas & EMBL: PRJEB7433 \\
Po82 & IIB-4 & 1 & Batata & México & GenBank: CP002819, CP002820 \\
UW163 & IIB-4 & 1 & Banana da Terra & Peru & EMBL: PRJEB7430 \\
CFBP7014 & IIB-59 & 1 & Antúrio & Trinidad & EMBL: PRJEB8309 \\
CMR15 & III & 1 & Tomate & Camarões & EMBL: FP885895, FP885896 \\
PSI07 & IV & 2 & Tomate & Indonésia & EMBL: FP885906, FP885891 \\
& & & & & \\
\hline
\end{tabular}

"_" sem informação.

2.6. Desenvolvimento de primers específicos para o gene codificador da sorbitol desidrogenase (um dos genes candidatos em associação com o perfil de biovares)

Primers foram gerados via subtração in silico dos genomas alinhados das diversas biovares disponíveis no GenBank e em outras bases de dados. Para a síntese do par de primers Sorb-B3, foram usadas as sequências do gene codificador da sorbitol desidrogenase dos genomas de R. pseudosolanacearum (biovar 3) disponíveis (Tabela 7). As diferentes sequências obtidas foram alinhadas e os primers foram desenhados pelo plugin Primer3 (Untergasser et al., 2012) e pelo programa PrimerSelect (Lasergene, Madison, WI). Na síntese dos primers, foram levadas em consideração as regiões comuns (conservadas) nas diferentes variantes do gene codificador da sorbitol desidrogenase bem como os critérios de conteúdo de GC, tamanho, compatibilidade entre pares de primers e ausência de auto-anelamento.

\subsection{Avaliação dos primers em gradientes de temperaturas de anelamento}

Os primers sintetizados foram testados em gradiente com as temperaturas de $60^{\circ} \mathrm{C}, 62^{\circ} \mathrm{C}$, $64^{\circ} \mathrm{C}, 66^{\circ} \mathrm{C}, 68^{\circ} \mathrm{C}$ e $70^{\circ} \mathrm{C}$. O programa de amplificação consistiu de um ciclo de $94^{\circ} \mathrm{C}$ por 5 minutos, seguido de 30 ciclos de $94^{\circ} \mathrm{C}$ por 30 segundos, para desnaturação, gradiente $\left(60^{\circ} \mathrm{C}\right.$ $70^{\circ} \mathrm{C}$ ) por 30 segundos para anelamento, e $72^{\circ} \mathrm{C}$ por 45 segundos para extensão, com extensão final de $72^{\circ} \mathrm{C}$ por 6 minutos. 


\section{RESULTADOS}

\subsection{Estabelecimento dos Bulks de isolados contrastantes para cada biovar}

Não participaram dos bulks isolados das biovares 4 e 5 (raças 4 e 5), uma vez que ainda não foram reportados no Brasil. A ausência de uma distribuição geográfica ampla de isolados de biovar 2A e 3, não permitiu uma diversificação muito grande durante a formação dos bulks, em especial dos isolados de biovar 2A, que ocorrem em locais de clima mais ameno e majoritariamente em batata.

\subsection{Uso do sistema de marcadores RAPD}

Foram identificados 11 primers que geraram padrões de fragmentos polimórficos entre isolados das quatro biovares (Tabela 8). Esses primers foram empregados em estudos posteriores buscando o desenvolvimento de primers específicos (Figura 8). Os primers OPI18, OP-J1, OP-O1, OP-K10 se mostraram polimórficos para a biovar 1; os primers OP-A7, OP-A15, OP-C20, OP-I18 e OP-J1 mostraram amplicons exclusivos para isolados da biovar 2A; primers OP-I18, OP-J1 e OP-O1 para isolados da biovar 2T; e os primers OP-A7, OPA10, OP-B10, OP-G11, OP-I3, OP-J1 e OP-K10 para isolados da biovar 3. Os amplicons apresentaram tamanhos variados e foram selecionados aqueles em um intervalo até $1700 \mathrm{pb}$.

Tabela 8. Lista das biovares e os respectivos primers RAPD com polimorfismos entre as biovares do complexo de espécies de Ralstonia.

\begin{tabular}{cccc} 
Biovar 1 & Biovar 2A & Biovar 2T & Biovar 3 \\
\hline OP-I18 & OP-A7 & OP-I18 & OP-A7 \\
OP-J1 & OP-A15 & OP-J1 & OP-A10 \\
OP-O1 & OP-C20 & OP-O1 & OP-B10 \\
OP-K10 & OP-I18 & & OP-G11 \\
& OP-J1 & & OP-I3 \\
& & & OP-J1 \\
& & & OP-K10 \\
\hline
\end{tabular}




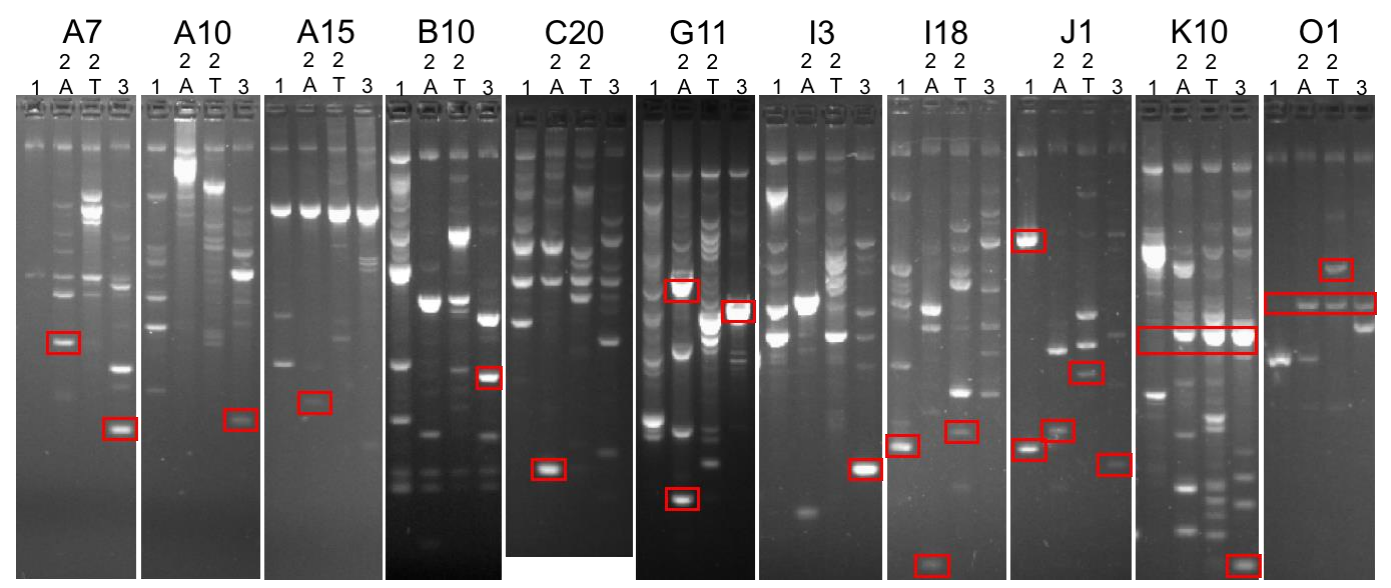

Figura 8. Painel de géis de agarose mostrando o perfil de amplicons resultantes de ensaios de PCR com um conjunto de primers RAPD (Operon). Os códigos dos primers empregados estão identificados na parte superior, seguido da biovar do bulk de isolados do complexo de espécies de Ralstonia.Em vermelho estão destacados os amplicons polimórficos.

Para validação dos polimorfismos, o DNA dos isolados foi amplificado individualmente com os mesmos primers (Figura 9). Esta análise reduziu o total de primers com polimorfismos estáveis para quatro. Para a biovar 1 foram validados os primers OP-J1 e OP-I18; biovar 2A, OP-I18, OP-A7; biovar 2T, J1; biovar 3, OP-A7 e OP-K10 (Tabela 9). 


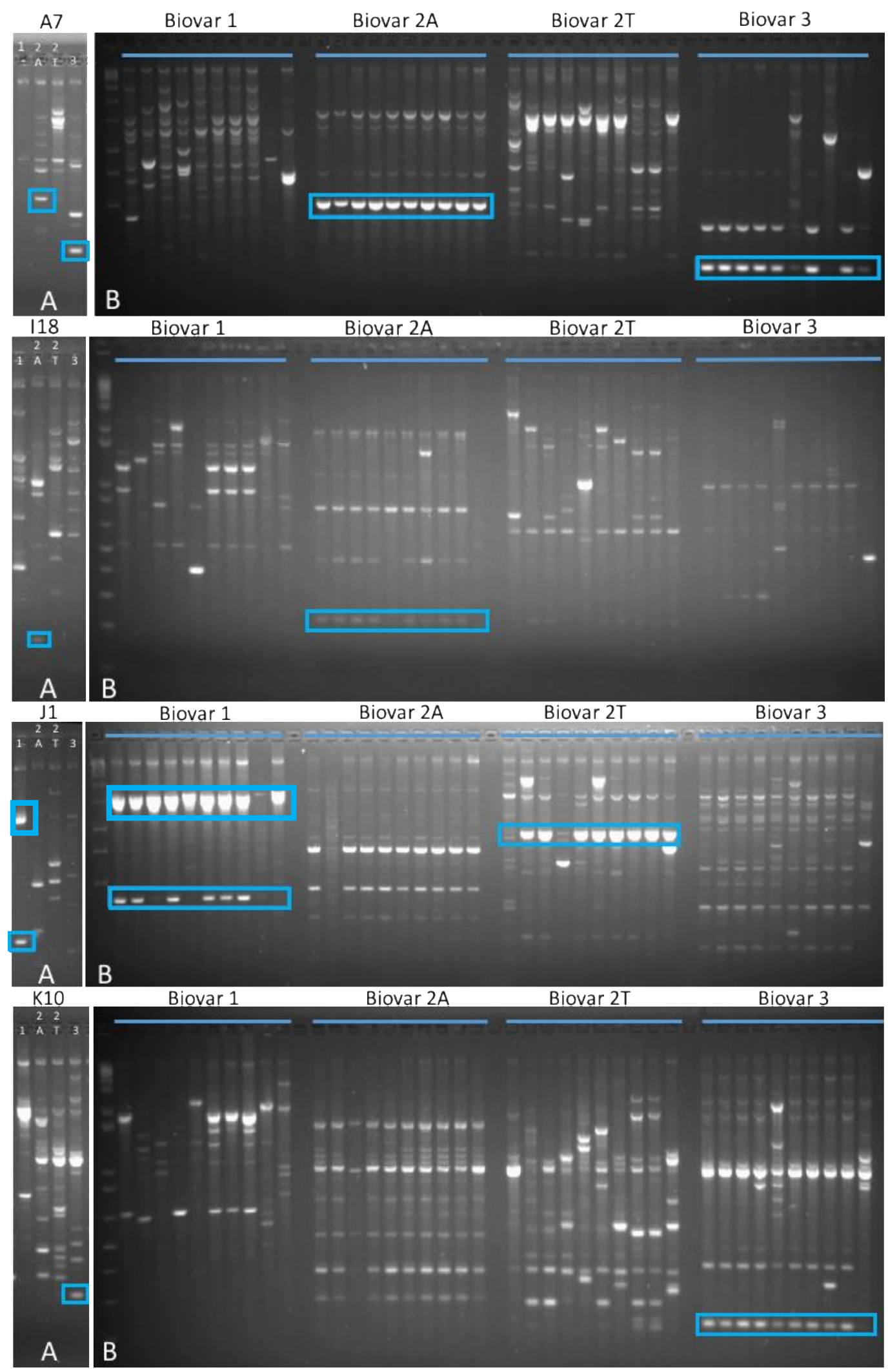

Figura 9. Géis de agarose após eletroforese das reações de PCR dos 10 DNAs dos isolados do complexo de espécies de Ralstonia que compuseram os quatro bulks das biovares 1, 2A, 2T e 3 com os primers RAPD OP-A7, OP-i18, OP-J1 e OP-K10. A - Segmento do gel de eletroforese 
da PCR com os bulks com quadrados em azul representando os amplicons exclusivos amplificados. B - Gel de eletroforese da PCR para validação do amplicon verificado no anterior.

Tabela 9. Primers RAPD utilizados por biovar estudada de isolados do complexo de espécies de Ralstonia com seus respectivos amplicons.

\begin{tabular}{cc}
\hline Biovar/Primer & $\begin{array}{c}\text { Tamanho amplicon } \\
\text { em pares de base } \\
\text { (pb) }\end{array}$ \\
\hline Biovar 1 & \\
\hline OP-J1 & 1700 \\
OP-J1 & 410 \\
\hline Biovar 2A & \\
\hline OP-A7 & 492 \\
OP-i18 & 186 \\
\hline Biovar 2T & \\
\hline OP-J1 & 938 \\
\hline Biovar 3 & \\
\hline OP-A7 & 232 \\
OP-K10 & 253 \\
\hline
\end{tabular}

\subsection{Clonagem e sequenciamento}

Após a validação dos marcadores com bulks abertos, um amplicon de cada região de interesse foi removido do gel, purificado, clonado e sequenciado. Seis fragmentos foram sequenciados e identificados pelo primer usado seguido da biovar, sendo então as sequências: J1-B1-B com 410 pb, J1-B1-A com 1700 pb, A7-B2A com 492, i18-B2A com 186, J1-B2T com 938, A7-B3 com 232, K10-B3 com 253.

\subsection{Desenho de primers}

Após montagem e correção manual das sequências foram buscadas regiões homólogas nos genomas do CER (Tabela 10). Dessas regiões foram desenhados um total de 25 primers (Tabela 11) para serem avaliados. 
Tabela 10. Lista dos pares de primers desenhados e dos amplicons sequenciados para marcadores gerados para cada biovar do complexo de espécies de Ralstonia, com suas respectivas características como: genoma com maior identidade com o amplicon sequenciado via análise com BLAST, anotação da região homóloga ao amplicon, porcentagem de identidade com a região homóloga, região dos amplicons correspondendo ao intervalo da sequência em que os primers anelam, e tamanho do amplicon. Tamanho amplicon SCARs se refere ao tamanho do fragmento gerado pelos primers SCARs, ou seja, desenhados como uma extensão do primer RAPD. O tamanho amplicon primers se refere ao fragmento gerado pelos primers desenhados internamente ao segmento sequenciado.

\begin{tabular}{|c|c|c|c|c|c|c|c|}
\hline Primer & $\begin{array}{l}\text { Genoma c/ } \\
\text { homologia }\end{array}$ & Gene & \%identidade & $\begin{array}{c}\text { Região dos } \\
\text { Primers SCARs }\end{array}$ & $\begin{array}{c}\text { Regiao dos } \\
\text { Primers }\end{array}$ & $\begin{array}{c}\text { Tamanho } \\
\text { amplicon } \\
\text { SCARs (pb) }\end{array}$ & $\begin{array}{c}\text { Tamanho } \\
\text { amplicon primers } \\
\text { (pb) }\end{array}$ \\
\hline J1-B1-A & FP885897 & $\begin{array}{l}\text { Isocitrate dehydrogenase } \\
(\mathrm{NADP}(+)) / \text { Região Intergênica / }\end{array}$ & 98,4 & - & $207-1685$ & - & 1478 \\
\hline J1-B1-B & FP885897 & $\begin{array}{l}\text { alpha,beta hydrolase CDS / } \\
\text { Região Intergênica }\end{array}$ & 99,0 & $1-408$ & $30-302$ & 408 & 273 \\
\hline A7-B2A & СР012688 & $\begin{array}{l}\text { 3',5'-cyclic adenosine } \\
\text { monophosphate }\end{array}$ & 99,4 & $1-492$ & $75-299$ & 492 & 225 \\
\hline I18-B2A & СР012687 & $\begin{array}{l}\text { hypothetical protein - Conserved } \\
\text { membrane protein }\end{array}$ & 99,5 & $1-186$ & $33-106$ & 186 & 74 \\
\hline J1-B2T & FP885906 & $\begin{array}{l}\text { Região Intergênica / putative type } \\
\text { III effector protein }\end{array}$ & 90,8 & $1-938$ & - & 938 & - \\
\hline A7-B3 & AL646052 & $\begin{array}{l}\text { putative transposase-related } \\
\text { protein CDS / Região intergênica }\end{array}$ & 99,6 & $1-232$ & $14-192$ & 232 & 179 \\
\hline K10-B3 & AL646053 & $\begin{array}{l}\text { probable remnant of a } \\
\text { transposase gene protein CDS / }\end{array}$ & 98,7 & $1-253$ & $1-97$ & 253 & 97 \\
\hline
\end{tabular}

“_” sem informação. 
Tabela 11. Lista de primers desenhados a partir dos sequenciamentos de fragmentos RAPD amplificados usando DNA genômico de isolados do complexo de espécies de Ralstonia de diferentes biovares. Os primers SCAR são listados com o prefixo "SCAR", os demais foram desenhados internamente baseados em polimorfismos visualizados na subtração in silico.

\begin{tabular}{|c|c|c|}
\hline Nome & Sequencias (5'-3') & Tamanho \\
\hline A7-B2A-F & ACGTTCAAAATCCTGGTCGT & \multirow{2}{*}{$225 \mathrm{pb}$} \\
\hline A7-B2A-R & GAGTCCTATGAACTGGCCCG & \\
\hline A7-B3-F & GAGGAGCGCGACATCCTAAA & \multirow{2}{*}{$179 \mathrm{pb}$} \\
\hline A7-B3-R & CAGAGGGAAGGTCAGGCTTG & \\
\hline i18-B2A-F & CGTGTCGATTGCGGTATTCG & \multirow{2}{*}{$74 \mathrm{pb}$} \\
\hline i18-B2A-R & CGAGCACGATTACAGTGGCT & \\
\hline J1-B1-B-F & TGCAAGGTGGCCATTCTCAT & \multirow{2}{*}{$274 \mathrm{pb}$} \\
\hline J1-B1-B-R & TGGGACGTTCTCGGAAATCG & \\
\hline J1-B1-A-F & CCCGGAGTAACCTTGAAGAA & \multirow{2}{*}{$1750 \mathrm{pb}$} \\
\hline J1-B1-A-R & CCCCGATAACCCCATCA & \\
\hline K10-B3-R & TTCTGGCTGCGGATTCAACT & $94 \mathrm{pb}$ \\
\hline Sorb-B3-1-F & CGACCAGACGCTTCTTCTCA & \multirow{2}{*}{$541 \mathrm{pb}$} \\
\hline Sorb-B3-3-R & CTCGTCGATTTGAAACCCGC & \\
\hline SCAR-A7-B2A-F & GAAACGGGTGATGGTGCATG & \multirow{2}{*}{$491 \mathrm{pb}$} \\
\hline SCAR-A7-B2A-R & GAAACGGGTGTGAACAGAAA & \\
\hline SCAR-A7-B3-F & GAAACGGGTGACCGAGGAGC & \multirow{2}{*}{$232 \mathrm{pb}$} \\
\hline SCAR-A7-B3-R & GAAACGGGTGCATAACCCAG & \\
\hline SCAR-i18-B2A-F & TGCCCAGCCTTGGCAATGGC & \multirow{2}{*}{$186 \mathrm{pb}$} \\
\hline SCAR-i18-B2A-R & TGCCCAGCCTGAAATTAGCT & \\
\hline SCAR-J1-B1-B-F & CCCGGCATAAAGAAACCGTA & \multirow{2}{*}{$408 \mathrm{pb}$} \\
\hline SCAR-J1-B1-B-R & CCCGGCATAAGCATTCTTGG & \\
\hline SCAR-J1-B2T-F & CCCGGCGTAATCTAAATGTG & \multirow{2}{*}{$936 \mathrm{pb}$} \\
\hline SCAR-J1-B2T-R & CAGGCAAACAGTCAATCAAA & \\
\hline SCAR-K10-B3-F & GTGCAACGTGGCAGTCTTAC & \multirow{2}{*}{$254 \mathrm{pb}$} \\
\hline SCAR-K10-B3-R & GTGCAACGTGCGGGAGGTGG & \\
\hline
\end{tabular}

\subsection{Análise das sequências dos amplicons polimórficos entre isolados contrastantes} para as diferentes biovares

A sequência J1-B1-A apresentou maior número de genomas (24) com homologia, identificados tanto com isolados biovar 1 como 2 e 3, com identidade variando entre 93,63\% e 98,4\%. A região foi fisicamente localizada dentro do DNA cromossomal, sendo identificada parcialmente como uma cópia do gene codificador de uma isocitrato desidrogenase. Esse gene 
codifica uma enzima associada com uma das principais rotas metabólicas de produção de energia, reduzindo NADPH para NADP+ (Garnak \& Reeves, 1979; Clark et al., 2016).

A sequência produzida com os pares de primers J1-B1-B apresentou homologia com o DNA cromossomal de um isolado, CFBP2957 da biovar 1 com 99\% de identidade, essa região cobre parcialmente o gene codificador da alpha/beta hidrolase. Este grupo de enzimas está estruturalmente relacionado com diversas funções catalíticas e cópias destes genes são encontradas em todos os genomas conhecidos (Lenfant et al., 2013). Alguns dos membros dessa família são acetilcolinesterase, dielactona hidrolase, lipase, tioesterase, carboxipeptidase tipo serina, prolina aminopeptidase, prolil oligopeptidase, haloalcano dehalogenase, haloperoxidase, epóxido hidrolase e hidroxinitrila liase entre outros (Holmquist, 2000).

A sequência obtida do amplicon A7-B2A apresentou homologia com regiões do DNA cromossomal e do megaplasmídeo de 19 isolados, de diferentes biovares, com identidade oscilando entre $77,3 \%$ e $99,39 \%$, tendo alta identidade com isolados biovar $2 \mathrm{~A}$. A sequência obtida do amplicon A7-B2A foi anotada como sequência parcial de uma fosfohidrolase.

A sequência i18-B2A apresentou homologia com DNA cromossomal de 27 isolados de diferentes biovares, com identidade variando entre $63,4 \%$ e $98,4 \%$. A região contém um segmento parcial de um gene codificador de uma proteína componente de membrana.

A sequência J1-B2T apresentou homologia com DNA cromossomal de oito isolados de diferentes biovares, com identidade variando entre $85,99 \%$ e 97,22\%. A sequência J1-B2T foi identificada como contendo o segmento de um gene codificador de uma proteína da classe serina-treonina quinase que foi previamente identificada como uma proteína efetora do tipo III (Remenant et al., 2010). 
A sequência A7-B3 somente teve homologia com o DNA cromossomal do isolado tipo GMI1000 com 99,14\% de identidade e anotada como o segmento parcial de um gene codificador de uma transposase (Reznikoff, 2008).

A sequência derivada do marcador K10-B3 teve homologia com o DNA cromossomal e do megaplasmídeo de 13 isolados, com identidade variando entre 37,39\% e 98,64\%, porém em regiões do genoma sem prévias e/ou detalhadas anotações.

\subsection{Avaliação do conjunto de primers obtidos entre isolados contrastantes para as}

\section{diferentes biovares}

O desenho dos primers seguiu o descrito no tópico 2.4. Os pares de primers J1-B1-B, SCAR-i18-B2A, SCAR-A7-B3, A7-B3, SCAR-K10-B3, K10-B3 e Sorb-B3 apresentaram amplicons específicos e de presença consistente entre os dez isolados selecionados de cada biovar. O par J1-B1-B amplificou de forma específica em sete dos dez isolados da biovar 1 (Figura 10); o par SCAR-i18-B2A amplificou isolados da biovar 2A e também amplificou isolados da biovar $2 \mathrm{~T}$ e com fragmentos de amplificação tênues foram observados em isolados da biovar 3. O par de primers Sorb-B3 amplificou somente isolados da biovar 3 com amplicon de tamanho aproximado de $541 \mathrm{pb}$. Os demais primers apresentaram-se inespecíficos nas condições testadas. As concentrações dos reagentes da PCR e programa do termociclador estão descritas na Tabela 12. 


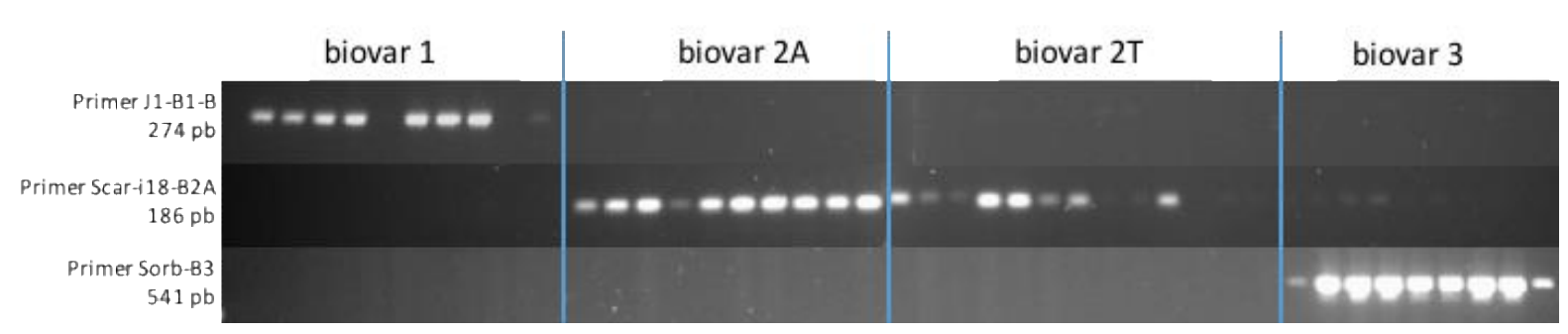

Figura 10. Painel de géis de eletroforese em gel de agarose com os produtos de PCR de dez isolados de cada biovar do complexo de espécies de Ralstonia com os pares de primers J1B1-B, SCAR-i18-B2A e Sorb-B3, ilustrando os níveis de especificidade de cada par.

Tabela 12. Condições utilizadas para a PCR e programa do termociclador para uso com os pares de primers J1-B1-B, SCAR-118-B2A e Sorb-B3.

\begin{tabular}{|c|c|c|c|c|c|}
\hline Reagentes PCR & $(\mu \mathrm{L})$ & Ciclos & Processo & Temp ${ }^{\circ} \mathrm{C}$ & Tempo \\
\hline Água & 6.1 & $1 \mathrm{X}$ & Desnaturação inicial & 94 & $4 \mathrm{~min}$ \\
\hline Tampão Taq & 1 & & Desnaturação & 95 & $30 \mathrm{seg}$ \\
\hline $\mathrm{MgCl} 2$ & 0.2 & $30 \mathrm{X}$ & Anelamento & 64 & $30 \mathrm{seg}$ \\
\hline dNTPs & 0.5 & & Extensão & 75 & $30 \mathrm{seg}$ \\
\hline Primer 1 & 0.5 & $1 \mathrm{X}$ & Extensão Final & 75 & $6 \mathrm{~min}$ \\
\hline Primer 2 & 0.5 & $4 \mathrm{X}$ & Resfriamento & 4 & $\infty$ \\
\hline Taq polimerase & 0.2 & & & & \\
\hline DNA & 1 & & & & \\
\hline TOTAL & 10 & & & & \\
\hline
\end{tabular}

\section{DISCUSSÃO}

Embora de execução laboratorial demorada, onerosa e trabalhosa, o sistema de classificação de biovares tem se mostrado muito informativo no ponto de vista prático, revelando associações com características peculiares dos diferentes isolados, tais como padrões de proteínas de membrana, nichos ecológicos, gama de plantas hospedeiras e distribuição geográfica (Dristig \& Dianese, 1990; Prior et al., 1990; Hayward, 1994b; Lopes et al., 1994; Netto et al., 2003). Isolados da raça 1/biovar 3 (R. pseudosolanacearum) têm se mostrado mais virulentos em espécies do gênero Capsicum (Lopes \& Boiteux, 2004), ao passo que isolados de raça 1/biovar 1 apresentam maior especificidade pelo tomateiro (Takatsu \& Lopes, 1997). Os isolados da raça 3/biovar 2A estão associados com a capacidade de causar murcha em 
temperaturas mais amenas quando comparados com isolados da biovar 2T (Lopes, 2005). Além disso, recentes resultados (Lopes et al., 2015) indicam que o cafeeiro (C. arabica) é afetado apenas por isolados da biovar 3 (R. pseudosolanacearum). A classificação de biovares pode ser ainda mais informativa quando acoplada com a determinação das raças (sensu Buddenhagen et al., 1962), como no caso da raça 3/biovar 2, que afeta solanáceas e gerânios (Williamson et al., 2002) e de isolados da raça 4/biovar 3, que ocorrem em gengibre (Kumar et al., 2014).

Nesse cenário, a disponibilidade de um sistema de marcadores moleculares baseados em DNA para determinação de biovares traria inúmeras vantagens relacionadas a custo, facilidade e escala de execução. Mesmo com a ampla aplicação prática demonstrada pelo sistema de biovares e o crescente número de genomas completos de $R$. solanacearum sequenciados, ainda não estão disponíveis e/ou validados métodos de detecção molecular de biovares derivados de informações e/ou anotações genômicas associadas diretamente com esse perfil bioquímico.

Visando estabelecer um robusto sistema de marcadores moleculares para identificação de biovares de $R$. solanacearum, uma coleção de 340 primers RAPD foi avaliada com DNA extraído de isolados pertencentes aos quatro biovares que ocorrem no Brasil (1, 2A, 2T e 3). Neste trabalho, foi possível encontrar um subconjunto de 3,23\% de primers capazes de gerar amplicons polimórficos e exclusivos para as biovares 1, 2A, 2T e 3. Esses níveis de polimorfismo foram relativamente baixos, mas estão potencialmente subestimados, uma vez que foram selecionados ou incluídos no presente estudo apenas fragmentos com intervalos arbitrários para os tamanhos mínimos e máximos dos amplicons (100 a 1000 bp).

A técnica de BSA acoplada com o sistema RAPD demonstrou ser uma técnica útil na identificação de polimorfismos e validação de marcadores para biovar. A eficiência da estratégia de BSA observada no presente estudo está em acordo com os estudos de identificação de genes associados a distintos "mating types" em Pleurotus ostreatus (Larraya et al., 2001) e 
de estudos de genes relacionados ao uso de xilose em Saccharomyces cerevisae (Wenger et al., 2010).

A disponibilidade de genomas de referência completos permitiu refinar o desenho de primers SCARs adicionando primers internos quando polimorfismos foram observados dentro de um amplicon polimórfico. O uso da estratégia de desenho de primers in silico e da subtração in silico para biovares e raças prevalentes no Brasil é dificultado pela inexistência de genomas completos disponíveis (especialmente de isolados obtidos no território brasileiro).

O desenho de primers combinando a informação de sequência dos amplicons mais a subtração in silico permitiu o desenho de dois pares de primers específicos, apesar da presença de algumas bandas inespecíficas tênues (SCAR-i18-B2 e J1-B1-B) e de um par de primers altamente específicio (Sorb-B3). Este último contou também com o fato de se tratar de um gene alvo específico da biovar 3. Desta forma, a subtração in silico mesmo diante das limitações encontradas (reduzido número de genomas disponíveis com biovar caracterizada), demonstrou ser uma alternativa viável para o desenho de primers de forma mais precisa, reduzindo possibilidade de erros, portanto, também os custos.

A sequência que apresentou o nível mais elevado de identidade com o fragmento obtido com os primers $\mathrm{J} 1-\mathrm{B} 1-\mathrm{B}$ (J1-B1-B-F e J1-B1-B-R) foi identificada englobando um potencial gene codificador de uma alpha/beta hidrolase. No caso do par de primers SCAR-i18-B2A (SCAR-i18-B2A-F e SCAR-i18-B2A-R), não foi possível verificar in silico o anelamento da região sequenciada com isolados de biovar 2T, devido à ausência de genomas identificados/caracterizados como sendo dessa biovar. De fato, uma fração considerável dos genomas sequenciados está sem uma caracterização apropriada, em especial para raça e biovar, dificultando a análise e interpretação dos resultados obtidos no presente trabalho. Ao contrário dos filotipos e das sequevares, a determinação de biovar necessita da conservação de isolados 
viáveis para a condução dos testes (Hayward, 1994a), o que pode dificultar a confirmação da potencial universalidade dos primers identificados no presente trabalho.

A especificidade para isolados da biovar 3 foi confirmada para o par de primers Sorb-B3. Para o único isolado com resultados contraditórios (ausência de amplicons específicos) foi posteriormente confirmado que o comportamento anômalo foi ocasionado por problemas de baixa qualidade do DNA genômico usado como molde nas reações iniciais de PCR. No entanto, é importante salientar que o par de primers Sorb-B3 não pode ser considerado como exclusivo da biovar 3, uma vez que o gene codificador da sorbitol desidrogenase (polS) está também presente em isolados de biovar 4 (Kanjanasopa et al., 2006). No entanto, para o conjunto de isolados brasileiros empregados no presente trabalho, o par de primers Sorb-B3 mostrou uma elevada especificidade.

A região de $22 \mathrm{~kb}$ descrita por Gabriel et al. (2006) como exclusiva da biovar 3 e provavelmente da biovar 4, mostrou elevado potencial de uso para o encontro de genes exclusivos, como o gene da sorbitol desidrogenase. Outros genes nessa região serão buscados futuramente visando a criação de mais marcadores associados com a biovar 3 e 4 .

A análise de sequência das regiões genômicas caracterizadas no presente trabalho indicaram polimorfismos em genes que não estão, aparentemente, relacionados de maneira direta com patogênese de patógenos do CER. A marcante exceção foi o segmento genômico obtido após sequenciamento do amplicon gerado pelo par de primes J1-B2T, que se trata de uma potencial proteína efetora. No entanto, a diversidade genética dessa região não permitiu distinguir as diferentes biovares, utilizando marcadores do tipo SCAR convencionais ou mesmo primers internos desenhados na região do SCAR.

A região A7-B3, apesar de polimórfica, é parcialmente composta por uma transposase, o que pode dificultar o seu uso como marcador por se tratar de uma região que pode ter várias 
cópias no genoma (Guidot et al., 2009). Em busca da identificação da família a qual esse elemento móvel pertence, não foi possível encontrar outro componente de transposon devidamente caracterizado por meio do BLAST. A sequência não foi somente encontrada em sequências brasileiras de isolados de filotipo I, como também nos genomas de referência GMI1000, FQY_4, YC45 e mais outros três genomas de filotipo III, podendo se tratar de uma região de relativamente baixa instabilidade genética.

Trabalhos adicionais visando a busca por primers específicos para isolados da biovar $2 \mathrm{~T}$ serão necessários. Essa variante é nativa do Brasil e se encontra atualmente disseminada em outras regiões fora da América do Sul (Nouri et al., 2009). Já foi observado que essa biovar apresenta outras características fenotípicas distintas da biovar 2A, causando doença em locais com temperaturas mais altas e apresentando uma gama de plantas hospedeiras mais ampla (Lopes, 2005).

O uso de primers específicos para cada biovar seria mais prático que o teste comum de meio de cultura de Hayward (1964). O tempo de 14 dias (considerado o período ideal para a avaliação das diferentes biovares em meio de cultura) impede uma análise rápida, precisa e em larga escala. A quantidade de reagentes empregada para a confecção do meio também é outro obstáculo, o custo dos reagentes e aplicação de seis fontes de carbono mais os componentes para o meio básico pode ser uma limitação, em especial se considerar que reagentes de PCR e termocicladores podem ser encontrados em praticamente qualquer laboratório e que seu custo continua em queda (Harris, 1998). A velocidade e praticidade da PCR não foram as únicas vantagens. Problemas de leitura do teste de meio de cultura (quando os diferentes carboidratos não alteram completamente sua cor para o amarelo) são comumente observados e representa outro importante inconveniente do método clássico de determinação de biovares. Nesse cenário, o emprego de um sistema de marcadores robusto para a identificação das diferentes biovares 
representa uma importante contribuição de ordem prática especialmente em estudos envolvendo um grande número de isolados.

\section{CONCLUSÕES}

- A estratégia de Bulked segregant analysis permitiu a identificação de marcadores polimórficos em isolados de diferentes biovares, mas apresentou baixos índices de efetividade de 3,21\% (número de polimorfismo em bulk/número de polimorfismos validados);

- A técnica de sequenciamento de regiões polimórficas reveladas pelo sistema RAPD em combinação com a localização física das sequências via análise de genomas in silico permitiu a identificação de um conjunto de sete pares de primers informativos (J1-B1-B, SCAR-i18B2A, SCAR-A7-B3, A7-B3, SCAR-K10-B3, K10-B3 e o primer no gene candidato Sorb-B3) para identificação de biovares;

- $\quad$ Os pares de primers J1-B1-B, SCAR-i18-B2A e Sorb-B3 apresentaram potencial utilidade para o estabelecimento de sistemas rápidos de identificação/distinção molecular de isolados das biovares 1,2 e 3 ;

- $\quad$ Primers capazes de gerar polimorfismos exclusivos para isolados da biovar 2T não foram identificados, demandando trabalhos adicionais de busca de marcadores.

\section{PERSPECTIVAS}

- Buscar novos fragmentos polimórficos com potencial para desenho de novos primers;

- Continuar o levantamento de características de isolados com genomas completos sequenciados;

- Desenvolver marcadores específicos para as biovares 1, 2A e 2T. 


\section{REFERÊNCIAS BIBLIOGRÁFICAS}

BUDDENHAGEN, I.W.; SEQUEIRA, L. \& KELMAN, A. 1962. Designation of races of Pseudomonas solanacearum. Phytopathology 52:726-730.

CLARK, O.; YEN, K. \& MELLINGHOFF, I.K. 2016. Molecular Pathways: Isocitrate Dehydrogenase Mutations in Cancer. Clinical Cancer Research 22:1837-1842.

DRISTIG, M.C.G. \& DIANESE, J.C. 1990. Characterization of Pseudomonas solanacearum biovars based on membrane protein patterns. Phytopathology 80:641-658.

FEGAN, M.; HOLOWAY, G.; HAYWARD, A.C. \& TIMMIS, J. 1998. Development of a diagnostic test based on the polymerase chain reaction (PCR) to identify strains of Ralstonia solanacearum exhibiting the biovar 2 genotype. In: PRIOR, P.; ALLEN, C. \& ELPHINSTONE, J. eds. Bacterial Wilt disease. Molecular and ecological aspects.1 ed.Springer. Alemanha. p. 34-43.

FEGAN, M. \& PRIOR, P. 2005. How complex is the Ralstonia solanacearum species complex? In: ALLEN, C.; PRIOR, P. \& HAYWARD, A.C. eds. Bacterial wilt disease and the Ralstonia solanacearum species complex.1 ed.APS Press. Estados Unidos. p. 449-461.

GABRIEL, D.W.; ALLEN, C.; SCHELL, M.; DENNY, T.P.; GREENBERG, J.T.; DUAN, Y.P.; FLORES-CRUZ, Z.; HUANG, Q.; CLIFFORD, J.M. \& PRESTING, G. 2006. Identification of open reading frames unique to a select agent: Ralstonia solanacearum race 3 biovar 2. Molecular Plant-Microbe Interactions 19:69-79.

GARNAK, M. \& REEVES, H.C. 1979. Phosphorylation of isocitrate dehydrogenase of Escherichia coli. Science 203:1111-1112.

GUIDOT, A.; ELBAZ, M.; CARRÈRE, S.; SIRI, M.I.; PIANZZOLA, M.J.; PRIOR, P. \& BOUCHER, C. 2009. Specific genes from the potato brown rot strains of Ralstonia solanacearum and their potential use for strain detection. Phytopathology 99:1105-1112.

GUND, S.V.; MOGER, N.; KRISHNARAJ, P.U.; BHAT, R. \& KAMANNA, B.C. 2011. Development of race specific SCAR marker for the detection of Ralstonia solanacearum (race 2). Journal of Applied Bioscience 37:91-96.

GUND, S.V.; NARAYAN, M.; KRISHNARAJ, P.U.; RAMESH, B. \& KAMANNA, B.C. 2013. Molecular Diagnostic Tool for Specific Identification of Ralstonia solanacearum through SCAR Marker. Indian Journal of Plant Protection 41:342-348.

HARRIS, E. 1998. A low-cost approach to PCR: appropriate transfer of biomolecular techniques. 1 Ed. Oxford University Press. Reino Unido.

HAYWARD, A. 1964. Characteristics of Pseudomonas solanacearum. Journal of Applied Bacteriology 27:265-277. 
HAYWARD, A.C. 1991. Biology and epidemiology of bacterial wilt caused by Pseudomonas solanacearum. Annual Review of Phytopathology 29:65-87.

HAYWARD, A.C. 1994a. The hosts of Pseudomonas solanacearum. In: HAYWARD, A.C. \& HARTMAN, G.L. eds. Pseudomonas solanacearum: The disease and its causative agent. 1 ed.CABI International. Reino Unido. p. 101-115.

HAYWARD, A.C. 1994b. Systematics and phylogeny of Pseudomonas solanacearum and related bacteria. In: HAYWARD, A.C. \& HARTMAN, G.L. eds. Bacterial Wilt: the Disease and its Causative Agent, Pseudomonas solanacearum.1 ed.CAB International. Estados Unidos. p. 123-135.

HE, L.Y.; SEQUEIRA, L. \& KELMAN, A. 1983. Characteristics of strains of Pseudomonas solanacearum from China. Plant Disease 67:1357-1361.

HOLMQUIST, M. 2000. Alpha beta-hydrolase fold enzymes structures, functions and mechanisms. Current Protein and Peptide Science 1:209-235.

HORITA, M. \& TSUCHIYA, K. 2001. Genetic diversity of Japanese strains of Ralstonia solanacearum. Phytopathology 91:399-407.

HORITA, M.; TSUCHIYA, K.; SUGA, Y.; YANO, K.; WAKI, T.; KUROSE, D. \& FURUYA, N. 2014. Current classification of Ralstonia solanacearum and genetic diversity of the strains in Japan. Journal of General Plant Pathology 80:455-465.

HUET, G. 2014. Breeding for resistances to Ralstonia solanacearum. Frontiers in Plant Science $5: 715$.

JAUNET, T.X. \& WANG, J.-F. 1999. Variation in genotype and aggressiveness of Ralstonia solanacearum race 1 isolated from tomato in Taiwan. Phytopathology 89:320-327.

KANJANASOPA, D.; CHATCHAWANKANPHANICH, O.; CHOWPONGPANG, S.; KOSITRATANA, W. \& THAVEECHAI, N. 2006. Characterization of the Sugar Utilization Gene polS from Ralstonia solanacearum. Kasetsart Journal Natural Science 40:10.

KEARSE, M.; MOIR, R.; WILSON, A.; STONES-HAVAS, S.; CHEUNG, M.; STURROCK, S.; BUXTON, S.; COOPER, A.; MARKOWITZ, S. \& DURAN, C. 2012. Geneious Basic: an integrated and extendable desktop software platform for the organization and analysis of sequence data. Bioinformatics 28:1647-1649.

KELMAN, A. 1954. The relationship of pathogenicity in Pseudomonas solanacearum to colony appearance on a tetrazolium medium. Phytopathology 44:693-695.

KUMAR, A.; PRAMEELA, T.P.; SUSEELABHAI, R.; SILJO, A.; ANANDARAJ, M. \& VINATZER, B.A. 2014. Host specificity and genetic diversity of race 4 strains of Ralstonia solanacearum. Plant Pathology 63:1138-1148. 
LARRAYA, L.M.; PÉREZ, G.; IRIBARREN, I.; BLANCO, J.A.; ALFONSO, M.; PISABARRO, A.G. \& RAMÍREZ, L.A. 2001. Relationship between monokaryotic growth rate and mating type in the edible basidiomycete Pleurotus ostreatus. Applied and Environmental Microbiology 67:3385-3390.

LEE, Y.-A. \& WANG, C.-C. 2000. The design of specific primers for the detection of Ralstonia solanacearum in soil samples by polymerase chain reaction. Botanical Bulletin of Academia Sinica 41:121-128.

LENFANT, N.; HOTELIER, T.; BOURNE, Y.; MARCHOT, P. \& CHATONNET, A. 2013. Proteins with an alpha/beta hydrolase fold: relationships between subfamilies in an evergrowing superfamily. Chemico-Biological Interactions 203:266-268.

LIM, S.H.; KIM, J.G. \& KANG, H.W. 2009. Novel SCAR primers for specific and sensitive detection of Agrobacterium vitis strains. Microbiological Research 164:451-460.

LOPES, C.A. 2005. Murchadeira da batata. 1 Ed. Associação Brasileira da Batata. Itapetininga.

LOPES, C.A. \& BOITEUX, L.A. 2004. Biovar-specific and borad-spectrum sources of resistance to bacterial wilt (Ralstonia solanacearum) in Capsicum. Crop Breeding and Applied Biotechnology 4:350-355.

LOPES, C.A.; QUEZADO-SOARES, A.M. \& DE MELO, P.E. 1994. Differential resistance of tomato cultigens to biovars I and III of Pseudomonas solanacearum. Plant Disease 78:1091-1094.

LOPES, C.A.; ROSSATO, M. \& BOITEUX, L.S. 2015. The host status of coffee (Coffea arabica) to Ralstonia solanacearum phylotype I isolates. Tropical Plant Pathology 40:14.

MADDEN, T.L.; TATUSOV, R.L. \& ZHANG, J. 1996. Applications of network BLAST server. Methods in Enzymology 266:131-141.

MAHUKU, G.S. 2004. A simple extraction method suitable for PCR-based analysis of plant, fungal, and bacterial DNA. Plant Molecular Biology Reporter 22:71-81.

MARQUES, E.; UESUGI, C.H.; FERREIRA, M.A.S.V. \& REZENDE, D.V.D. 2012. Characterization of isolates of Ralstonia solanacearum biovar 2, pathogenic to Eucalyptus "urograndis" hybrids. Tropical Plant Pathology 37:399-408.

MICHELMORE, R.W.; PARAN, I. \& KESSELI, R.V. 1991. Identification of markers linked to disease-resistance genes by bulked segregant analysis: A rapid method to detect markers in specific genomic regions by using segregating populations. Proceedings of the National Academy of Sciences USA 88:9828-9832. 
NETTO, R.A.C.; PEREIRA, B.G.; NODA, H. \& BOHER, B. 2003. Caracterização de isolados de Ralstonia solanacearum obtidos de tomateiros em várzea e em terra firme, no Estado do Amazonas. Fitopatologia Brasileira 28:362-366.

NORMAN, D.J.; ZAPATA, M.; GABRIEL, D.W.; DUAN, Y.; YUEN, J.M.; MANGRAVITANOVO, A. \& DONAHOO, R.S. 2009. Genetic diversity and host range variation of Ralstonia solanacearum strains entering North America. Phytopathology 99:1070-1077.

NOURI, S.; BAHAR, M. \& FEGAN, M. 2009. Diversity of Ralstonia solanacearum causing potato bacterial wilt in Iran and the first record of phylotype II/biovar 2T strains outside South America. Plant Pathology 58:243-249.

OPINA, N.; TAVNER, F.; HOLLWAY, G.; WANG, J.; LI, T.; MAGHIRANG, R.; FEGAN, M.; HAYWARD, A.; KRISHNAPILLAI, V. \& HONG, W. 1997. A novel method for development of species and strain-specific DNA probes and PCR primers for identifying Burkholderia solanacearum (formerly Pseudomonas solanacearum). Asia-Pacific Journal of Molecular Biology and Biotechnology 5:19-30.

PAN, Z.; XU, J.; PRIOR, P.; XU, J.; ZHANG, H.; CHEN, K.; TIAN, Q.; ZHANG, L.; LIU, L. \& HE, L. 2013. Development of a specific molecular tool for the detection of epidemiologically active mulberry causing-disease strains of Ralstonia solanacearum phylotype I (historically race 5-biovar 5) in China. European Journal of Plant Pathology 137:377-391.

PARAN, I. \& MICHELMORE, R.W. 1993. Development of reliable PCR-based markers linked to downy mildew resistance genes in lettuce. Theoretical and Applied Genetics 85:985-993.

PRIOR, P.; STEVA, H. \& CADET, P. 1990. Aggressiveness of stains of Pseudomonas solanacearum from the French West Indies (Martinique and Guadeloupe) on tomato. Plant Disease 74:962-965.

QUARRIE, S.A.; LAZIĆ-JANČIĆ, V.; KOVAČEVIĆ, D.; STEED, A. \& PEKIĆ, S. 1999. Bulk segregant analysis with molecular markers and its use for improving drought resistance in maize. Journal of Experimental Botany 50:1299-1306.

REMENANT, B.; COUPAT-GOUTALAND, B.; GUIDOT, A.; CELLIER, G.; WICKER, E.; ALLEN, C.; FEGAN, M.; PRUVOST, O.; ELBAZ, M. \& CALTEAU, A. 2010. Genomes of three tomato pathogens within the Ralstonia solanacearum species complex reveal significant evolutionary divergence. BMC Genomics 11:379-395.

REZNIKOFF, W.S. 2008. Transposon Tn 5. Annual review of genetics 42:269-286.

SANTANA, B.G.; LOPES, C.A.; ALVAREZ, E.; BARRETO, C.C.; ALLEN, C. \& QUIRINO, B.F. 2012. Diversity of Brazilian biovar 2 strains of Ralstonia solanacearum Journal of General Plant Pathology 78:190-200. 
SANTIAGO, T.R.; LOPES, C.A.; CAETANO-ANOLLÉS, G. \& MIZUBUTI, E.S.G. 2016. Phylotype and sequevar variability of Ralstonia solanacearum in Brazil, an ancient center of diversity of the pathogen. Plant Pathology.

SEAL, S.; JACKSON, L.; YOUNG, J. \& DANIELS, M. 1993. Differentiation of Pseudomonas solanacearum, Pseudomonas syzygii, Pseudomonas pickettii and the blood disease bacterium by partial $16 \mathrm{~S}$ rRNA sequencing: construction of oligonucleotide primers for sensitive detection by polymerase chain reaction. Journal of general microbiology 139:1587-1594.

STULBERG, M.J.; SHAO, J. \& HUANG, Q. 2015. A multiplex PCR assay to detect and differentiate select agent strains of Ralstonia solanacearum. Plant Disease 99:333-341.

TAKATSU, A. \& LOPES, C.A. 1997. Murcha bacteriana em hortaliças: avanços científicos e perspectivas de controle. Horticultura Brasileira 15:170-177.

UNTERGASSER, A.; CUTCUTACHE, I.; KORESSAAR, T.; YE, J.; FAIRCLOTH, B.C.; REMM, M. \& ROZEN, S.G. 2012. Primer3-new capabilities and interfaces. Nucleic Acids Research 40:e115.

WENGER, J.W.; SCHWARTZ, K. \& SHERLOCK, G. 2010. Bulk segregant analysis by highthroughput sequencing reveals a novel xylose utilization gene from Saccharomyces cerevisiae. PLoS Genetics 6:e1000942.

WICKER, E.; GRASSART, L.; CORANSON-BEAUDU, R.; MIAN, D.; GUILBAUD, C.; FEGAN, M. \& PRIOR, P. 2007. Ralstonia solanacearum strains from Martinique (French West Indies) exhibiting a new pathogenic potential. Applied and Environmental Microbiology 73:6790-6801.

WICKER, E.; LEFEUVRE, P.; DE CAMBIAIRE, J.-C.; LEMAIRE, C.; POUSSIER, S. \& PRIOR, P. 2012. Contrasting recombination patterns and demographic histories of the plant pathogen Ralstonia solanacearum inferred from MLSA. The ISME Journal 6:961974.

WILLIAMS, J.G.K.; KUBELIK, A.R.; LIVAK, K.J.; RAFALSKI, J.A. \& TINGEY, S.V. 1990. DNA polymorphisms amplified by arbitrary primers are useful as genetic markers. Nucleic Acids Research 18:6531-6535.

WILLIAMSON, L.; NAKAHO, K.; HUDELSON, B. \& ALLEN, C. 2002. Ralstonia solanacearum race 3, biovar 2 strains isolated from geranium are pathogenic on potato. Plant Disease 86:987-991.

XU, X.; CHAO, J.; CHENG, X.; WANG, R.; SUN, B.; WANG, H.; LUO, S.; XU, X.; WU, T. \& LI, Y. 2016. Mapping of a novel race specific resistance gene to Phytophthora root rot of pepper (Capsicum annuum) using bulked segregant analysis combined with specific length amplified fragment sequencing strategy. PloS One 11:e0151401. 
YABUUCHI, E.; KOSAKO, Y.; YANO, I.; HOTTA, H. \& NISHIUCHI, Y. 1995. Transfer of two Burkholderia and an Alcaligenes species to Ralstonia gen. nov.: proposal of Ralstonia pickettii (Ralston, Palleroni and Doudoroff 1973) comb. nov., Ralstonia solanacearum (Smith 1896) comb. nov. and Ralstonia eutropha (Davis 1969) comb. nov. Microbiology and Immunology 39:897-904. 


\section{CAPÍTULO 3}

BUSCA POR FONTES DE RESISTÊNCIA A ISOLADOS DE Ralstonia solanacearum DIVERGENTES EM RELAÇÃO À CAPACIDADE DE INFECTAR A LINHAGEM Solanum lycopersicum 'HAWAII 7996' 


\section{Busca por fontes de resistência a isolados de Ralstonia solanacearum divergentes em relação à capacidade de infectar a linhagem Solanum lycopersicum 'Hawaii 7996'}

\section{RESUMO}

O controle da murcha bacteriana do tomateiro causada pelo complexo de espécies de Ralstonia pode ser feito com o uso de cultivares resistentes. No entanto, a existência de isolados capazes de suplantar a resistência da linhagem 'Hawaii 7996' ressalta a necessidade de antecipar ações de pesquisa nos programas de melhoramento visando buscar por novas fontes de resistência para esses isolados considerados atípicos. O objetivo deste capítulo foi avaliar uma coleção de genótipos de tomateiro silvestre da espécie Solanum peruvianum visando identificar fontes resistência a dois isolados contrastantes quanto a capacidade de suplantar a resistência da linhagem 'Hawaii 7996'. Foram empregados os isolados $R$. solanacearum CNPH-RS 488 (da raça 3/biovar 2A, que foi reportado suplantando a resistência de 'Hawaii 7996' no Estado do Paraná) e ao isolado $R$. solanacearum CNPH-RS 489 (da raça 1/biovar 1 para o qual a linhagem 'Hawaii 7996' se mostra resistente). As respostas dos 75 genótipos de S. peruvianum foram comparadas aos controles resistente ('Hawaii 7996') e a suscetível (linhagem 'L390'). Em uma inoculação por aspersão do torrão da plântula com suspensão bacteriana na concentração a $10^{7}$ ufc/mL foi possível observar, em três dias após a inoculação, o aparecimento de plantas murchas da linhagem suscetível 'L390'. A diferença entre respostas dos genótipos de $S$. peruvianum para os dois isolados empregados no presente estudo ressaltam um possível envolvimento de diferentes mecanismos de resistência. Para o isolado CNPH-RS 488, 16 acessos foram promissores, contra 31 para o isolado CNPH-RS 489. Somente sete acessos ('CNPH 201', ‘CNPH 864', ‘CNPH 938', ‘CNPH 940', ‘CNPH 1035', 'CNPH 1194' e ‘CNPH 1382') apresentaram resistência simultânea para os dois isolados.

Palavras-chave: germoplasma, murcha bacteriana e Solanum peruvianum. 


\title{
Search for sources of resistance to Ralstonia solanacearum isolates that display contrasting abilities to infect the Solanum lycopersicum 'Hawaii 7996'
}

\begin{abstract}
The control of the bacterial wilt of tomatoes (caused by Ralstonia species complex) can be accomplished by the use of resistant cultivars and root-stocks. However, the detection of 'Hawaii 7996' resistance-breaking isolates highlights the need for preemptive breeding programs, focusing on the search of new resistance sources of resistance for this kind of atypical isolate. The objective of this chapter was to search for new sources of bacterial wilt disease resistance within Solanum peruvianum accessions. Two contrasting isolates were employed: $R$. solanacearum CNPH-RS 488 (race 3/ biovar 2A isolate reported causing severe wilt symptons in 'Hawaii 7996'-derived material in Paraná State, Brazil) and one standard, non-resistance breaking isolate $R$. solanacearum CNPH-RS, 489 (race 1/biovar 1). The reactions of $75 S$. peruvianum accessions were compared to the inbred lines 'Hawaii 7996' (resistant standard) and 'L390' (susceptible standard). The inoculation was carried out by spraying inoculum directly to the plant root system with a bacterial suspension adjusted to $10^{7} \mathrm{cfu} / \mathrm{mL}$. Symptoms on the susceptible control ('L390') start appearing three days after inoculation. The clear-cut differences in the response among S. peruvianum accessions for both isolates indicated the potential presence of distinct resistance mechanisms. Sixteen accessions displayed promising resistant reaction to the isolate CNPH-RS 488 and 31 to the CNPH-RS 489 isolate. Only seven ('CNPH 201', 'CNPH 864', 'CNPH 938', 'CNPH 940', 'CNPH 1035', 'CNPH 1194', and 'CNPH 1382') out of the 75 S. peruvianum accessions showed resistance to both isolates.
\end{abstract}

Keywords: bacterial wilt, germplasm and Solanum peruvianum. 


\section{INTRODUÇÃO}

\subsection{O complexo de espécies de Ralstonia, agente causal da murcha bacteriana do tomateiro.}

O complexo de espécies de Ralstonia (CER) (agente causal da murcha bacteriana) é um dos principais grupos de fitopatógenos do mundo, afetando mais de 200 espécies de plantas em 50 famílias botânicas (Genin \& Denny, 2012). No Brasil, a murcha bacteriana é considerada um dos principais problemas sanitários do cultivo do tomateiro e outras solanáceas em condições de cultivo protegido e é o principal fator limitante para produção de tomate na região amazônica (Lopes, 2015).

Originalmente o CER foi classificado em raças (Buddenhagen et al., 1962), biovares (Hayward, 1964), filotipos e sequevares (Fegan \& Prior, 2005). Essa extensa variabilidade indicava que esse grupo de patógenos era composto por um complexo de espécies. De fato, tratamentos taxonômicos mais recentes (levando em consideração técnicas genômicas e proteômicas) resultaram na divisão do táxon em três espécies distintas: Ralstonia solanacearum, R. pseudosolanacearum e $R$. syzygii (Safni et al., 2014). A espécie $R$. solanacearum, previamente composta por isolados da raça 3/biovar 2, era originalmente considerada a "raça da batata" (Hayward, 1991). O relato da murcha bacteriana em gerânio no Brasil indicou o agente causal como sendo um isolado da biovar 2 (Almeida et al., 2003). Essa doença do gerânio veio se tornar um problema sério nos Estados Unidos e no continente europeu, em que estacas com infecções latentes levaram à disseminação da doença (Norman $e t$ al., 2009). Em 2012 foram relatados isolados da biovar 2 causando murcha em plantações de Eucalyptus (Marques et al., 2012). Diversos outros relatos de hospedeiras dessa raça e biovar foram feitos no mundo, ressaltando que isolados raça 3/biovar 2, antes considerados restritos à batata e outras solanáceas, apresentam, na realidade, uma maior gama de hospedeiras. 
Isolados do CER são um grande desafio para a produção do tomateiro no Brasil e no mundo. Esse grupo de patógenos se destaca pela persistência no solo por longos períodos, podendo também colonizar a rizosfera de plantas invasoras e/ou nativas, favorecendo a manutenção de sua população de um cultivo a outro (Lin et al., 2009).

\subsection{O controle da murcha bacteriana via melhoramento genético}

A murcha bacteriana é uma doença extremamente destrutiva, com muitos relatos de perdas que variam de acordo com a cultura. No cultivo do tomateiro, são comuns os registros de perdas totais, na batata, de 33 a 90\%; na banana, 80 a 100\%; e no amendoim de $20 \%$ (Elphinstone, 2005).

Entre 1997 e 2005 foram relatados na literatura cerca de 450 estudos sobre o CER, 24\% desses abordando melhoramento e 18\% sobre controle e manejo (Elphinstone, 2005; Nion \& Toyota, 2015). De fato, poucas opções de controle da murcha bacteriana estão disponíveis; entre elas pode-se citar a rotação de culturas (Yadessa et al., 2010; Deberdt et al., 2015), agentes de controle biológico (Yamamoto et al., 2015) e técnicas de enxertia (Rivard et al., 2012; Lopes \& Mendonça, 2016). Entretanto, a estratégia mais eficiente e prática tem sido, quando disponível, o uso de cultivares resistentes, devido ao seu baixo custo, maior eficiência e menor dano ao meio ambiente (Strange \& Scott, 2005; Jianwei et al., 2010; Wang et al., 2013; Hanson et al., 2016; Zhao et al., 2016).

Em tomateiro uma das fontes mais empregadas tem sido a linhagem Solanum lycopersicum 'Hawaii 7996', considerada como padrão de resistência à murcha bacteriana (Wang et al., 2013). A resistência de 'Hawaii 7996' é determinada por diversos QTLs que conferem um amplo espectro de eficiência (Wang et al., 1998; Carmeille et al., 2006a; Lebeau et al., 2011; Wang et al., 2013). Como relatado por Wang et al. (2013) e Wang et al. (1998), a resistência derivada de 'Hawaii 7996' tem se mostrado estável e de amplo espectro, com 
elevadas taxas de sobrevivência em experimentos de campo conduzidos em 11 países em diferentes continentes. 'Hawaii 7996' e os materiais derivados dessa linhagem têm sido empregados como porta-enxertos, apresentando resultados positivos em termos da expressão da resistência contra isolados de raça 1 biovar 1 (filotipo II) e raça 1 biovar 3 (filotipo I) (Lopes et al., 2015).

Devido a esse conjunto de características, o acesso 'Hawaii 7996' tem sido largamente usado em programas de melhoramento genético visando incorporar a resistência para murcha bacteriana. No entanto, para diversificar a base genética da resistência, distintas fontes derivadas de espécies selvagens também têm sido empregadas, tais como acessos de $S$. pennellii (Hai et al., 2008), S. pimpinellifolium (Jaworski et al., 1987) e S. peruvianum (Carmeille et al., 2006b).

\subsection{Solanum peruvianum e seu potencial como fonte de genes de resistência a} doenças

A espécie S. peruvianum foi inicialmente classificada como Lycopersicum peruvianum (L.) Miller. Estudos taxonômicos mais recentes subdividiram essa espécie em quatro taxa filogeneticamente relacionados: S. peruvianum, S. huaylasense, S. corneliomuelleri e $S$. arcanum (Peralta et al., 2005). Solanum peruvianum é uma espécie selvagem de tomateiro, primariamente encontrada no Peru e também ao longo do litoral Oeste da América do Sul, nos Andes e norte do Chile (Chetelat et al., 2009). No Chile, a espécie S. peruvianum está amplamente disseminada como uma planta invasora em consequência de sua elevada fecundidade (mais sementes por fruto e com florescimento mais precoce) quando comparada com outras espécies do gênero Solanum (Chetelat et al., 2009). Solanum peruvianum é considerada a espécie mais variável entre os parentes selvagens do tomateiro (Julián et al., 2013). É uma espécie predominantemente auto-incompatível. Além disso, seu uso como parental feminino (receptor de pólen) em cruzamentos interespecíficos com acessos de 
tomateiro tem sido evitado devido à existência de incompatibilidade unilateral (Hogenboom, 1972; Julián et al., 2013). Outra complicação associada com o uso de S. peruvianum no melhoramento do tomateiro tem sido os baixos níveis de compatibilidade de cruzamento com o tomateiro cultivado ( $S$. lycopersicum), demandando, muitas vezes, a necessidade de estratégias de resgate de embrião in vitro (Domínguez et al., 2005).

Mesmo diante dessas limitações, a espécie S. peruvianum tem sido extensivamente empregada no melhoramento genético do tomateiro devido aos inúmeros fatores de resistência contra estresses abióticos (Julián et al., 2013) tais como: tolerância à salinidade (Tal, 1971) e tolerância ao frio (Fernández-Muñoz et al., 1995). Além disso, acessos dessa espécie representam uma fonte de inúmeros genes de resistência contra fatores bióticos (doenças e artrópodes-praga) que estão atualmente sendo empregados nos programas de melhoramento genético do tomateiro.

Mais de 40 genes de resistência foram caracterizados em $S$. peruvianum e outras espécies selvagens (Rick \& Chetelat, 1995). Acessos de S. peruvianum foram fontes de importantes genes de resistência tais como: Asc para resistência ao fungo Alternaria alternata (van der Biezen et al., 1995), Frl para Fusarium oxysporum f. sp. radicis-lycopersici (Vakalounakis et al., 1997), py-1 para resistência ao fungo Pyrenochaeta lycopersici (Doganlar et al., 1998), Tm2-2 para resistência a distintos patotipos de Tomato mosaic virus (Young et al., 1988), Sw-5 que controla resistência ampla contra espécies de Tospovirus (Stevens et al., 1991; Boiteux \& Giordano, 1993; Stevens et al., 1995), Ve para Verticillium dahliae raça 1 (Diwan et al., 1999), Mi-1 e Mi-3 para resistência aos nematoides das galhas (Yaghoobi et al., 2005) e fatores de resistência quantitativa ao cancro bacteriano (Clavibacter michiganensis subsp. michiganensis) (Sen et al., 2013). Em relação os agentes causadores da murcha bacteriana, existem relatos de acessos de $S$. peruvianum com resistência parcial à raça 3 biovar 2 (filotipo II) (Carmeille et al., 2006b). 
O presente trabalho tem como objetivo ampliar a caracterização de acessos de espécies silvestres do gênero Solanum e explorar o potencial uso do germoplasma de S. peruvianum no melhoramento genético para resistência aos agentes causadores da murcha bacteriana. Além disso, é importante antecipar a busca por fontes de resistência contra novos isolados com perfil de virulência mais amplo e capazes de “quebrar” a resistência da linhagem 'Hawaii 7996'. Essa estratégia (denominada de melhoramento antecipatório ou 'preemptive breeding') é importante visando encontrar soluções genéticas antes que a potencial disseminação desses isolados se torne um problema epidêmico. Neste contexto, o presente trabalho representa uma busca por novas fontes de resistência à murcha bacteriana em uma coleção de 75 genótipos da espécie $S$. peruvianum, utilizando o isolado CNPH-RS 488 (que é capaz de quebrar a resistência da linhagem 'Hawaii 7996') e um isolado da raça 1/biovar 1 (CNPH-RS 489) que não se mostra virulento nessa linhagem.

\section{MATERIAL E MÉTODOS}

\subsection{Seleção de isolados}

O isolado CNPH-RS 488 foi obtido em 2012 a partir de plantas de porta-enxerto comercial de tomateiro (catalogado como sendo resistente à murcha bacteriana) que apresentava severos sintomas da doença em Grandes Rios, no Estado do Paraná. Experimentos conduzidos posteriormente na Embrapa Hortaliças confirmaram a capacidade, desse isolado, em "quebrar" a resistência da linhagem S. lycopersicum 'Hawaii 7996' (Lopes et al., 2015), reconhecida como uma das principais fontes de resistência à murcha bacteriana (Wang et al., 2013). O isolado CNPH-RS 488 foi posteriormente caracterizado (vide capitulo 2 dessa dissertação) como sendo pertencente à raça 3 (conhecida como "raça da batata"); biovar 2A (geralmente associada com a capacidade de causar murcha em temperaturas mais amenas) (Khoodoo et al., 2010); filotipo II, de origem geográfica no continente americano (Santana et al., 2012), e sequevar 1, que é importante como causador de grandes perdas na cultura da batata 
(Guidot et al., 2009). Em outros testes, o isolado CNPH-RS 488 também apresentou uma gama de plantas hospedeiras mais ampla e um perfil de virulência mais amplo, sendo capaz de, inclusive, infectar acessos de berinjela (S. melongena), jiló ( $S$. aethiopicum var. gilo) e Capsicum spp., que são mais tolerantes aos isolados de biovar 2 e geralmente mais suscetíveis aos isolados das biovares 1 e 3 (ver capítulo 2).

Outro isolado selecionado foi denominado de CNPH-RS 489. Esse isolado foi caracterizado como sendo da raça 1/biovar 1, que é uma raça associada com uma maior gama de hospedeiras e de origem endêmica no Brasil (Lopes, 2005) e filotipo II. A sequevar desse isolado ainda não foi determinada. Em testes prévios foi demonstrada sua maior agressividade em tomateiro, se tornando um isolado com potencial valor em sistemas de seleção de genótipos resistentes. Ambos os isolados são da coleção de bactérias da Embrapa Hortaliças, que são mantidos armazenados em tubos criogênicos com água mineral sob condições de temperatura ambiente.

\subsection{Genótipos utilizados nas avaliações}

Setenta e cinco genótipos de $S$. peruvianum pertencentes ao banco de germoplasma da Embrapa Hortaliças foram selecionados para serem desafiados com os isolados CNPH-RS 488 e CNPH-RS 489. As linhagens testemunhas foram a 'Hawaii 7996' (padrão de resistência) e 'L390' (padrão de suscetibilidade) (Wang et al., 2013; Kurabachew \& Wydra, 2014). Os genótipos foram semeados em bandejas de poliestireno de 128 células preenchidas com substrato esterilizado. Plantas foram mantidas em casa de vegetação até o estádio fisiológico de quatro folhas verdadeiras.

\subsection{Preparo do inóculo}

Os isolados foram riscados em placas de Petri com meio CPG (Kelman, 1954) com modificações (substituição da glicose por glicerol) e incubados em câmara de crescimento por 
48 horas, $28^{\circ} \mathrm{C}$. Após esse período, colônias típicas foram selecionadas e repicadas. Para a produção do inóculo, as colônias foram raspadas com a ajuda de uma alça de Drigalsky e transferidas para um béquer com água. As suspensões foram homogeneizadas e calibradas para $10^{7} \mathrm{UFC} / \mathrm{mL}$ com um espectrofotômetro, logo em seguida colocadas em vasilhames com borrifadores portáteis manuais.

\subsection{Inoculação e avaliação}

Para a inoculação, as plantas foram removidas da bandeja e o torrão foi pulverizado com aproximadamente $4 \mathrm{~mL}$ de suspensão bacteriana contendo cerca de $5 \times 10^{7} \mathrm{ufc} / \mathrm{mL}$ (Lopes et al., 2015). As diferenças no padrão de desenvolvimento inicial das linhagens testemunhas ('L390' e 'Hawaii 7996') e dos genótipos de S. peruvianum em avaliação dificultaram a padronização da idade fisiológica da planta no momento da inoculação. No entanto, a maioria dos genótipos foi inoculada com cerca de quatro folhas verdadeiras. Imediatamente após a inoculação, as plantas foram transferidas para vasos de $0,5 \mathrm{~L}$ e mantidas na casa de vegetação, com temperatura oscilando entre 20 e $40{ }^{\circ} \mathrm{C}$ com aquecimento suplementar noturno. Plantas “inoculadas" apenas com água destilada foram usadas como controle negativo. As avaliações começaram aos três dias após a inoculação devido à alta suscetibilidade de alguns genótipos e continuaram por até 13 dias após a inoculação. O experimento foi delineado como inteiramente casualizado com duas repetições com número variado de plantas por genótipo, devido à variação na germinação das sementes. A análise de área abaixo da curva de progresso da doença (AACPD) foi calculada por meio dos programas computacionais Excel ${ }^{\circledR}$ do Microsoft Office $2016^{\circledR}$ e a análise estatística pelo programa SISVAR (Ferreira, 2011) pelo método de ScottKnott $5 \%$. 


\section{RESULTADOS}

\subsection{Avaliação de genótipos de tomateiro do banco de germoplasma da Embrapa}

\section{Hortaliças}

As inoculações com os dois isolados indicaram divergências em relação às respostas dos genótipos de $S$. peruvianum e das duas linhagens testemunhas ('Hawaii 7996' e 'L390') (Figura 11). O controle suscetível 'L390' murchou rapidamente com ambos os isolados, confirmando a virulência do inóculo. Nenhuma das plantas do controle negativo (com água) apresentou sintomas.

O isolado CNPH-RS 488, mesmo causando níveis mais elevados de doença, não foi capaz de causar murcha em $100 \%$ das plantas avaliadas, indicando a existência de genótipos com potencial uso no melhoramento genético (Figura 11). Quatro grupos foram formados após análise estatística da frequência de plantas murchas usando o isolado CNPH-RS 488. O grupo A foi formado por 16 genótipos classificados com elevada resistência; o grupo $\mathrm{B}$, composto por 23 genótipos, com resistência intermediária alta; grupo $\mathrm{C}$, formado por 22 genótipos com resistência intermediária baixa (incluindo a linhagem 'Hawaii 7996'); e o grupo D composto por 14 genótipos que foram classificados com tendo baixa resistência (incluindo o controle suscetível 'L390'). A linhagem 'Hawaii 7996' foi incluída no grupo de genótipos significativamente menos suscetíveis que os demais.

Os 69 genótipos avaliados com o isolado CNPH-RS 489 foram divididos em três grupos estatísticos de acordo com a reação à inoculação. O grupo A (identificado como resistente), foi formado por 31 genótipos (incluindo a linhagem 'Hawaii 7996'); o grupo B (de resistência intermediária) foi composto por 26 genótipos (juntamente com a linhagem 'L390'); e o grupo C foi formado por 12 genótipos classificados como sendo suscetíveis, ou seja, S. peruvianum apresenta acessos ainda mais suscetíveis do que ‘L390’ (padrão de suscetibilidade). Entretanto, pode ter sido devido à interferência da idade fisiológica da muda inoculada, maior para L390, 
que provavelmente germinou mais rapidamente e teve maior vigor. Considerando esse resultado, somente os genótipos componentes do grupo A apresentaram níveis promissores de resistência ao isolado CNPH-RS 489.

Não foi possível comparar os valores absolutos de AACPD entre o isolado CNPH-RS 488 (biovar 2A) e o isolado CNPH-RS 489 (biovar 1), uma vez que a velocidade e os índices de murcha divergiram entre os experimentos. Para o isolado CNPH-RS 488, a murcha dos genótipos suscetíveis ocorreu mais rapidamente (Figura 11), forçando o encerramento do experimento mais cedo, quando comparado com o ensaio conduzido com o isolado CNPH-RS 489. Com o isolado CNPH-RS 488 ocorreu suplantação de resistência, resultando em plantas murchas na testemunha resistente 'Hawaii 7996', o mesmo não ocorreu com o isolado CNPHRS 489, que não induziu murcha nessa linhagem. A linhagem 'L390' se agrupou sempre entre os genótipos de media alta ou alta suscetibilidade nos dois experimentos. Foi possível verificar divergências nos níveis de resistência/suscetibilidade entre os genótipos ao isolado CNPH-RS 489. A linhagem 'Hawaii 7996' não apresentou nenhuma planta murcha, enquanto que os demais genótipos não alcançaram esse nível de resistência para esse isolado de biovar 1 . Genótipos originalmente identificados como resistentes ao CNPH-RS 489 não apresentaram, de maneira consistente, resposta similar quando inoculados com o isolado CNPH-RS 488. Os resultados das inoculações confirmaram, portanto, que a linhagem 'Hawaii 7996', é resistente ao isolado CNPH-RS 489, mas se mostrou suscetível (grupo de resistência intermediária baixa) quando inoculada com o isolado CNPH-RS 488. 


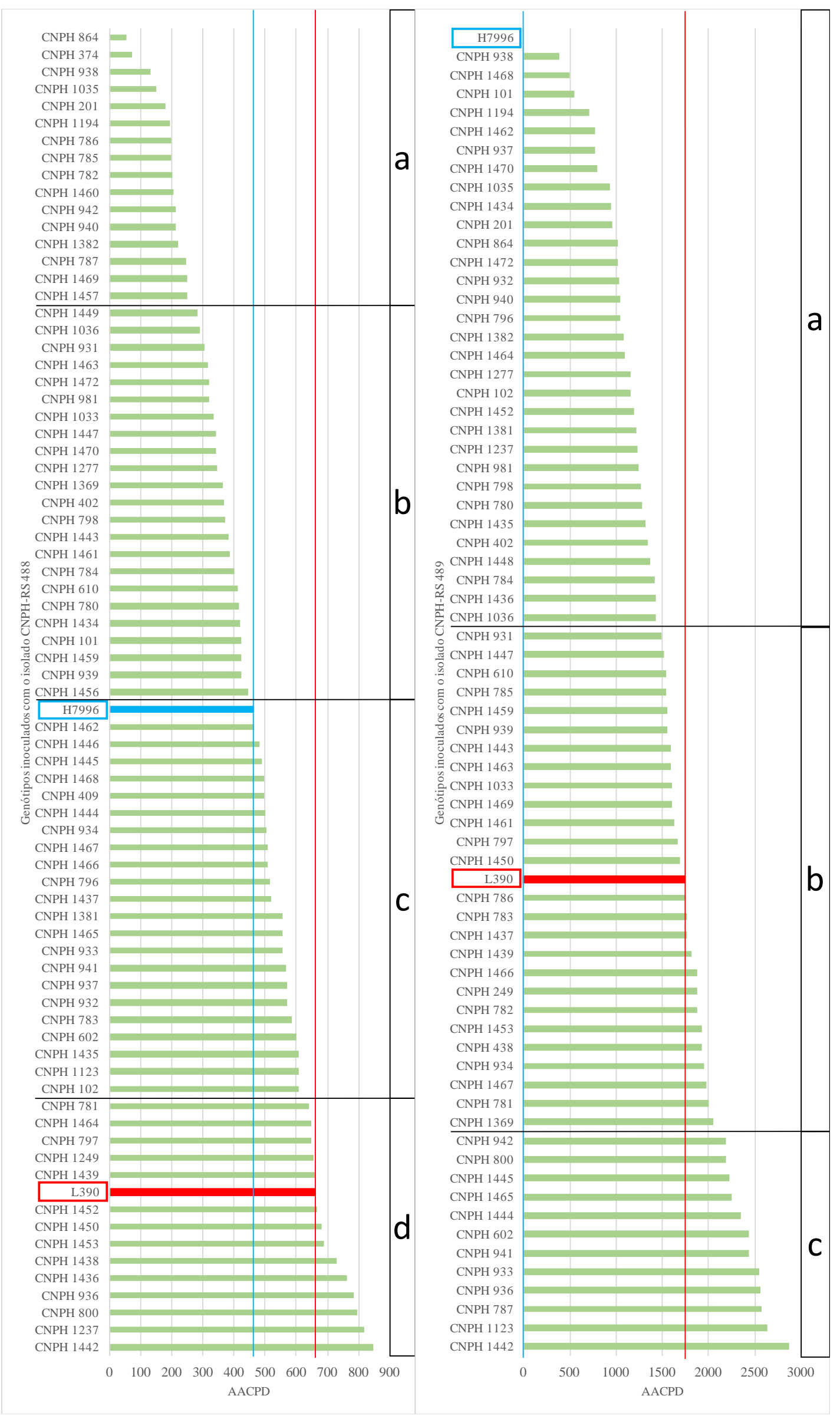


Figura 11. Gráfico da análise da área abaixo da curva de progresso da doença (AACPD) de 75 genótipos de Solanum peruvianum avaliados quanto sua resistência à murcha bacteriana com os isolados CNPH-RS 488 (raça 3/biovar 2A) e CNPH-RS 489 (raça 1/biovar 1). Os acessos foram comparados com as linhagens 'Hawaii 7996' (controle resistente) e 'L390' (controle suscetível). A barra vermelha indica o resultado da linhagem suscetível ('L390') e em azul o resultado da linhagem resistente ('Hawaii 7996'). Quadros com letras indicam os grupos estatísticos formados pelo teste Scott-Knott ao nível de significância de 5\%.

\section{DISCUSSÃO}

Segundo Hayward (1991) e Lopes \& Boiteux (2012) a resposta de resistência pode variar de acordo com método de inoculação, a concentração do inóculo e as condições ambientais. Boiteux \& Monma (1994) também observaram diferenças na frequência de escapes devido à inoculação de mudas com diferentes idades. A rápida murcha do genótipo 'L390' nos dois ensaios e a sobrevivência de diversos genótipos em avaliação indicaram que tanto a concentração de inóculo como as condições ambientais foram adequadas para discriminar a resposta dos genótipos. A eficiência para a comparação de genótipos apresentada pelo método de inoculação com jatos da suspensão bacteriana em torrões intactos se deve ao fato de que a remoção das mudas da bandeja per se já promove algum dano aos sistemas radiculares, servindo de porta de entrada para o patógeno.

Os índices de murcha encontrados nas linhagens testemunhas confirmam dados anteriores de que 'L390' é adequada como controle suscetível (Kurabachew \& Wydra, 2013; Li et al., 2014; Hanson et al., 2016). A linhagem 'Hawaii 7996' tem sido empregada como controle resistente (Wang et al., 1998), porém já existem relatos que essa resistência pode ser "quebrada" por alguns isolados (Milling et al., 2011), fato também observado no presente trabalho (vide capítulo 1). Mostrando a importância que representa identificar algum acesso que possa ser usado como referência de resistência quando se for avaliar para a raça 3/biovar 2 . 
A caracterização da agressividade e virulência do isolado CNPH-RS 488 na linhagem $S$. lycopersicum 'Hawaii 7996' foi o tema do capítulo 1 da presente tese. No entanto, não foi possível, pelos testes empregados, elucidar alguns dos fatores associados com essa característica peculiar desse isolado. Os mecanismos poderão ser potencialmente elucidados por meio do sequenciamento deste isolado e pela análise de regiões do genoma que indiquem a presença de fatores genéticos associados com a capacidade de quebra de resistência, assim como outras características que esse isolado possa ter em comparação com outros isolados da biovar 2A (de elevada agressividade) que foram previamente sequenciados, tais como o UY031 do Uruguai (Guarischi-Sousa et al., 2016).

A identificação de genótipos de $S$. peruvianum com índices de doença inferiores ao do 'Hawaii 7996' após inoculação com o isolado CNPH-RS 488 demonstra a possibilidade do uso desses genótipos como fontes de resistência. Servindo como alternativas para expandir a base genética para essa característica em programas de melhoramento genético do tomateiro e antecipar problemas decorrentes da potencial expansão geográfica de isolados com perfil de virulência similar ao do isolado CNPH-RS 488.

Solanum peruvianum já foi amplamente utilizada como fonte doadora de fatores resistência estáveis e duráveis contra uma gama de patógenos tais como A. alternata (van der Biezen et al., 1995), F. oxysporum f. sp. radicis-lycopersici (Vakalounakis et al., 1997); P. lycopersici (Doganlar et al., 1998), ToMV (Young et al., 1988); Tospovirus (Stevens et al., 1991; Stevens et al., 1995), V. dahliae (Diwan et al., 1999), nematoides das galhas (Yaghoobi et al., 2005) e cancro bacteriano (C. michiganensis subsp. michiganensis) (Sen et al., 2013).

Para o CER, já existem relatos de genótipos de S. peruvianum apresentando resistência a diferentes isolados, em especial da raça 3/biovar 2 (filotipo II) (Kim et al., 2016). Carmeille et al. (2006b) relataram genótipos moderadamente resistentes em germoplasma de S. peruvianum. 
Em um trabalho de avaliação de germoplasma conduzido por Hai et al. (2008) foram avaliados 252 acessos de tomateiros selvagens, entre esses, 42 de $S$. peruvianum, porém nenhum se mostrou resistente, ou seja, com resistência similar à da linhagem 'Hawaii 7996'. Kim et al. (2016) identificaram somente duas fontes de resistência (com média de 0 a $50 \%$ de folhas murchas por planta) em uma coleção de 285 genótipos desta espécie.

A diferença entre respostas dos genótipos de $S$. peruvianum para os dois isolados empregados no presente estudo ressaltam um possível envolvimento de diferentes mecanismos de resistência. Para o isolado CNPH-RS 488, 16 acessos foram promissores, contra 31 para o isolado CNPH-RS 489. No entanto, somente sete acessos ('CNPH 201', 'CNPH 864', 'CNPH 938', 'CNPH 940', 'CNPH 1035', 'CNPH 1194' e 'CNPH 1382') apresentaram resistência simultânea para os dois isolados.

A resistência do tipo filotipo I-específica conferida pelo QTL Bwr-12 na linhagem ‘Hawaii 7996' está associada com limitação da colonização bactéria (Wang et al., 2013). Já o QTL Bwr-6 também contribui com a resistência para filotipo I e amplia a resistência para isolados da raça 3/biovar 2. Essa resistência está em estreita ligação (em repulsão) ou pode ser alélica ao locus $M i$ (que confere resistência a espécies de Meloidogyne), dificultando a piramidização dessas duas características (Deberdt et al., 1999; Wang et al., 2013). No presente trabalho não foi utilizado nenhum isolado do filotipo I (raça 1/biovar 3) para confirmar se os acessos promissores de S. peruvianum também apresentam resistência à infecção contra essas variantes, impedindo uma análise adequada quanto a essa capacidade. Os mecanismos de resistência à murcha bacteriana associados com a espécie $S$. peruvianum nunca foram elucidados e os potenciais fatores genéticos ainda necessitam ser mapeados, o que dificulta, momentaneamente, o processo de melhoramento empregando essas fontes. 
Isolados da biovar 2A são reconhecidos por induzir doença em condições de temperaturas mais baixas e são os principais agentes causais de infecções latentes em tubérculos de batata (Ciampi et al., 1980) e em estacas de gerânio (Swanson et al., 2005). Diferentes genótipos de S. peruvianum foram identificados apresentando níveis de resistência superiores a aqueles apresentados pela linhagem 'Hawaii 7996'. Esse fato leva ao questionamento da potencial presença de infecções latentes (Prior et al., 1996) nestes genótipos classificados como resistentes. O mecanismo de resistência, geralmente atribuído à limitação da colonização dos tecidos do sistema vascular (Grimault \& Prior, 1993; Bittner et al., 2016) pode ser uma explicação para o não aparecimento de sintomas de murcha, porém pode estar associado com a presença da bactéria nos tecidos da planta. Esse tipo de resistência representa um risco inerentemente associado com patógenos de solo. Para avaliar de forma mais detalhada a eficiência de cultivares resistentes na supressão da doença e de infecções latentes, já existem protocolos empregando isolados geneticamente modificados para emissão de luminescência (Cruz et al., 2014) que podem auxiliar na diagnose de infecções latentes.

\section{CONCLUSÕES}

* Alguns acessos de S. peruvianum mostraram potencial para uso no melhoramento para a raça 1/biovar 1 e raça 3/biovar 2, inclusive ao isolado CNPH-RS 488 (capaz de suplantar a resistência da linhagem 'Hawaii 7996’);

* Essas novas fontes de resistência descritas no presente trabalho podem, desta forma, representar fontes de fatores de resistência visando antecipar o potencial problema de disseminação de isolados com perfil de virulência similar ao observado para o isolado CNPH-RS 488.

\section{PERSPECTIVAS}

- Realizar coletas para verificar a existência, predominância e proporção de isolados com perfil de virulência similar ao do isolado CNPH-RS 488; 
- Sequenciar o genoma completo do isolado CNPH-RS 488 e conduzir análises genômicas comparativas com isolados semelhantes, mas que não são capazes de induzir murcha na linhagem 'Hawaii 7996';

- Estudar a capacidade do isolado CNPH-RS 488 de causar murcha em 'Hawaii 7996'e outros genótipos em temperaturas mais amenas (ex. $\left.25^{\circ} \mathrm{C}\right)$;

- Avaliar a estabilidade da resistência dos novos acessos diante de oscilações de temperaturas e contra uma gama mais ampla de isolados;

- Avaliar os acessos promissores com isolados de R. pseudosolanacearum filotipo I (raça 1/biovar 3).

\section{REFERÊNCIAS BIBLIOGRÁFICAS}

ALMEIDA, I.M.G.; DESTÉFANO, S.A.L.; RODRIGUES NETO, J. \& MALAVOLTA JÚNIOR, V.A. 2003. Southern bacterial wilt of geranium caused by Ralstonia solanacearum biovar 2/race 3 in Brazil. Revista de Agricultura 78:49-56.

BITTNER, R.J.; ARELLANO, C. \& MILA, A.L. 2016. Effect of temperature and resistance of tobacco cultivars to the progression of bacterial wilt, caused by Ralstonia solanacearum. Plant and Soil 408:1-12.

BOITEUX, L.S. \& GIORDANO, L.D.B. 1993. Genetic basis of resistance against two Tospovirus species in tomato (Lycopersicon esculentum). Euphytica 71:151-154.

BOITEUX, L.S. \& MONMA, S. 1994. Effect of plant age on expression of the resistance to Pseudomonas solanacearum in tomato in response to root dipping inoculation. Fitopatologia Brasileira 19:102-106.

BUDDENHAGEN, I.W.; SEQUEIRA, L. \& KELMAN, A. 1962. Designation of races of Pseudomonas solanacearum. Phytopathology 52:726-730.

CARMEILlE, A.; CARANTA, C.; DINTINGER, J.; PRIOR, P.; LUISETTI, J. \& BESSE, P. 2006a. Identification of QTLs for Ralstonia solanacearum race 3-phylotype II resistance in tomato. Theoretical and Applied Genetics 113:110-121.

CARMEILlE, A.; PRIOR, P.; KODJA, H.; CHIROLEU, F.; LUISETTI, J. \& BESSE, P. 2006b. Evaluation of resistance to race 3, biovar 2 of Ralstonia solanacearum in tomato germplasm. Journal of Phytopathology 154:398-402. 
CHETELAT, R.T.; PERTUZÉ, R.A.; FAÚNDEZ, L.; GRAHAM, E.B. \& JONES, C.M. 2009. Distribution, ecology and reproductive biology of wild tomatoes and related nightshades from the Atacama Desert region of northern Chile. Euphytica 167:77-93.

CIAMPI, L.; SEQUEIRA, L. \& FRENCH, E.R. 1980. Latent infection of potato tubers by Pseudomonas solanacearum. American Potato Journal 57:377-386.

CRUZ, A.P.Z.; FERREIRA, V.; PIANZZOLA, M.J.; SIRI, M.I.; COLL, N.S. \& VALLS, M. 2014. A novel, sensitive method to evaluate potato germplasm for bacterial wilt resistance using a luminescent Ralstonia solanacearum reporter strain. Molecular Plant-Microbe Interactions 27:277-285.

DEBERDT, P.; GOZÉ, E.; CORANSON- BEAUDU, R.; PERRIN, B.; FERNANDES, P.; LUCAS, P. \& RATNADASS, A. 2015. Crotalaria spectabilis and Raphanus sativus as Previous Crops Show Promise for the Control of Bacterial Wilt of Tomato Without Reducing Bacterial Populations. Journal of Phytopathology 163:377-385.

DEBERDT, P.; OLIVIER, J.; THOQUET, P.; QUÉNÉHERVÉ, P. \& PRIOR, P. 1999. Evaluation of bacterial wilt resistance in tomato lines nearly isogenic for the Mi gene for resistance to root-knot. Plant Pathology 48:415-424.

DIWAN, N.; FLUHR, R.; ESHED, Y.; ZAMIR, D. \& TANKSLEY, S.D. 1999. Mapping of Ve in tomato: a gene conferring resistance to the broad-spectrum pathogen, Verticillium dahliae race 1. Theoretical and Applied Genetics 98:315-319.

DOGANLAR, S.; DODSON, J.; GABOR, B.; BECK-BUNN, T.; CROSSMAN, C. \& TANKSLEY, S.D. 1998. Molecular mapping of the py-1 gene for resistance to corky root rot (Pyrenochaeta lycopersici) in tomato. Theoretical and Applied Genetics 97:784-788.

DOMÍNGUEZ, E.; CUARTERO, J. \& FERNÁNDEZ-MUÑOZ, R. 2005. Breeding tomato for pollen tolerance to low temperatures by gametophytic selection. Euphytica 142:253-263.

ELPHINSTONE, J.G. 2005. The current bacterial wilt situation: a global overview. In: ALLEN, C.; PRIOR, P. \& HAYWARD, A.C. eds. Bacterial wilt disease and the Ralstonia solanacearum species complex.1 ed.APS Press. Estados Unidos. p. 9-28.

FEGAN, M. \& PRIOR, P. 2005. How complex is the Ralstonia solanacearum species complex? In: ALLEN, C.; PRIOR, P. \& HAYWARD, A.C. eds. Bacterial wilt disease and the Ralstonia solanacearum species complex.1 ed.APS Press. Estados Unidos. p. 449-461.

FERNÁNDEZ-MUÑOZ, R.; GONZÁLEZ-FERNÁNDEZ, J.J. \& CUARTERO, J. 1995. Genetics of the viability of pollen grain produced at low temperatures in Lycopersicon Mill. Euphytica 84:139-144.

FERREIRA, D.F. 2011. Sisvar: a computer statistical analysis system. Ciência e Agrotecnologia 35:1039-1042. 
GENIN, S. \& DENNY, T.P. 2012. Pathogenomics of the Ralstonia solanacearum species complex. Annual Review of Phytopathology 50:67-89.

GRIMAULT, V. \& PRIOR, P. 1993. Bacterial wilt resistance in tomato associated with tolerance of vascular tissues to Pseudomonas solanacearum. Plant Pathology 42:589-594.

GUARISCHI-SOUSA, R.; PUIGVERT, M.; COLL, N.S.; SIRI, M.I.; PIANZZOLA, M.J.; VALLS, M. \& SETUBAL, J.C. 2016. Complete genome sequence of the potato pathogen Ralstonia solanacearum UY031. Standards in Genomic Sciences 11:1-9.

GUIDOT, A.; ELBAZ, M.; CARRÈRE, S.; SIRI, M.I.; PIANZZOLA, M.J.; PRIOR, P. \& BOUCHER, C. 2009. Specific genes from the potato brown rot strains of Ralstonia solanacearum and their potential use for strain detection. Phytopathology 99:1105-1112.

HAI, T.T.H.; ESCH, E. \& WANG, J.-F. 2008. Resistance to Taiwanese race 1 strains of Ralstonia solanacearum in wild tomato germplasm. European Journal of Plant Pathology 122:471-479.

HANSON, P.; LU, S.-F.; WANG, J.-F.; CHEN, W.; KENYON, L.; TAN, C.-W.; TEE, K.L.; WANG, Y.-Y.; HSU, Y.-C. \& SCHAFLEITNER, R. 2016. Conventional and molecular marker-assisted selection and pyramiding of genes for multiple disease resistance in tomato. Scientia Horticulturae 201:346-354.

HAYWARD, A. 1964. Characteristics of Pseudomonas solanacearum. Journal of Applied Bacteriology 27:265-277.

HAYWARD, A.C. 1991. Biology and epidemiology of bacterial wilt caused by Pseudomonas solanacearum. Annual Review of Phytopathology 29:65-87.

HOGENBOOM, N.G. 1972. Breaking breeding barriers in Lycopersicon: The genus Lycopersicon, its breeding barriers and the importance of breaking these barriers. Euphytica 21:221-227.

JAWORSKI, C.A.; PHATAK, S.C.; GHATE, S.R.; GITAITIS, R.D. \& WIDRLECHNER, M.P. 1987. Ga 1565-2-4 Bwt, Ga 219-1-2 Bwt, Ga 1095-1-4 Bwt, And Ga 1405-1-2 Bwt bacterial wilt-tolerant tomato. HortScience (USA) 22:324-325.

JIANWEI, L.; HUIFANG, J.; XIAOPING, R.; XIAOJIE, Z. \& BOSHOU, L. 2010. Identification and molecular traits of ICRISAT mini core collection of peanut species with resistance to bacterial wilt. Chinese Agriculture Science Bulletin 26:47-51.

JULIÁN, O.; HERRÁIZ, J.; CORELLA, S.; DI-LOLLI, I.; SOLER, S.; DÍEZ, M.J. \& PÉREZDE-CASTRO, A. 2013. Initial development of a set of introgression lines from Solanum peruvianum PI 126944 into tomato: exploitation of resistance to viruses. Euphytica 193:183-196. 
KELMAN, A. 1954. The relationship of pathogenicity in Pseudomonas solanacearum to colony appearance on a tetrazolium medium. Phytopathology 44:693-695.

KHOODOO, M.H.R.; GANOO, E.S. \& SAUMTALLY, A.S. 2010. Molecular Characterization and Epidemiology of Ralstonia solanacearum Race 3 biovar 2 Causing Brown Rot of Potato in Mauritius. Journal of Phytopathology 158:503-512.

KIM, S.G.; HUR, O.-S.; RO, N.-Y.; KO, H.-C.; RHEE, J.-H.; SUNG, J.S.; RYU, K.-Y.; LEE, S.-Y. \& BAEK, H.J. 2016. Evaluation of Resistance to Ralstonia solanacearum in Tomato Genetic Resources at Seedling Stage. The Plant Pathology Journal 32:58-64.

KURABACHEW, H. \& WYDRA, K. 2013. Characterization of plant growth promoting rhizobacteria and their potential as bioprotectant against tomato bacterial wilt caused by Ralstonia solanacearum. Biological Control 67:75-83.

KURABACHEW, H. \& WYDRA, K. 2014. Induction of systemic resistance and defenserelated enzymes after elicitation of resistance by rhizobacteria and silicon application against Ralstonia solanacearum in tomato (Solanum lycopersicum). Crop Protection $57: 1-7$.

LEBEAU, A.; DAUNAY, M.C.; FRARY, A.; PALLOIX, A.; WANG, J.F.; DINTINGER, J.; CHIROLEU, F.; WICKER, E. \& PRIOR, P. 2011. Bacterial wilt resistance in tomato, pepper, and eggplant: genetic resources respond to diverse strains in the Ralstonia solanacearum species complex. Phytopathology 101:154-165.

LI, C.-H.; WANG, K.-C.; HONG, Y.-H.; CHU, T.-H.; CHU, Y.-J.; CHOU, I.C.; LU, D.-K.; CHEN, C.-Y.; YANG, W.-C. \& LIN, Y.-M. 2014. Roles of different forms of lipopolysaccharides in Ralstonia solanacearum pathogenesis. Molecular Plant-Microbe Interactions 27:471-478.

LIN, C.-H.; HSU, S.-T.; TZENG, K.-C. \& WANG, J.-F. 2009. Detection of race 1 strains of Ralstonia solanacearum in field samples in Taiwan using a BIO-PCR method. European Journal of Plant Pathology 124:75-85.

LOPES, C.A. 2005. Murchadeira da batata. 1 Ed. Associação Brasileira da Batata. Itapetininga.

LOPES, C.A. 2015. Bacterial Wilt - a disease threatening disease of tomato cultivated under warm temperatures. Comunicado Técnico 109:4.

LOPES, C.A.; BOITEUX, L.S. \& ESCHEMBACK, V. 2015. Eficácia relativa de portaenxertos comerciais de tomateiro no controle da murcha-bacteriana. Horticultura Brasileira 33:125-130.

MILLING, A.; BABUJEE, L. \& ALLEN, C. 2011. Ralstonia solanacearum extracellular polysaccharide is a specific elicitor of defense responses in wilt-resistant tomato plants. PloS One 6:e15853. 
NION, Y.A. \& TOYOTA, K. 2015. Recent trends in control methods for bacterial wilt diseases caused by Ralstonia solanacearum. Microbes and Environments 30:1-11.

PERALTA, I.E.; KNAPP, S. \& SPOONER, D.M. 2005. New species of wild tomatoes (Solanum section Lycopersicon: Solanaceae) from Northern Peru. Systematic Botany 30:424-434.

PRIOR, P.; BART, S.; LECLERCQ, S.; DARRASSE, A. \& ANAIS, G. 1996. Resistance to bacterial wilt in tomato as discerned by spread of Pseudomonas (Burholderia) solanacearum in the stem tissues. Plant Pathology 45:720-726.

RICK, C.M. \& CHETELAT, R.T. Utilization of related wild species for tomato improvement. Proceedings of the I International Symposium on Solanacea for Fresh Market 412, 1995, 21-38.

RIVARD, C.L.; O'CONNELL, S.; PEET, M.M.; WELKER, R.M. \& LOUWS, F.J. 2012. Grafting tomato to manage bacterial wilt caused by Ralstonia solanacearum in the southeastern United States. Plant Disease 96:973-978.

SAFNI, I.; CLEENWERCK, I.; DE VOS, P.; FEGAN, M.; SLY, L. \& KAPPLER, U. 2014. Polyphasic taxonomic revision of the Ralstonia solanacearum species complex: proposal to emend the descriptions of Ralstonia solanacearum and Ralstonia syzygii and reclassify current $R$. syzygii strains as Ralstonia syzygii subsp. syzygii subsp. nov., $R$. solanacearum phylotype IV strains as Ralstonia syzygii subsp. indonesiensis subsp. nov., banana blood disease bacterium strains as Ralstonia syzygii subsp. celebesensis subsp. nov. and $R$. solanacearum phylotype I and III strains as Ralstonia pseudosolanacearum sp. nov. International Journal of Systematic and Evolutionary Microbiology 64:3087-3103.

SANTANA, B.G.; LOPES, C.A.; ALVAREZ, E.; BARRETO, C.C.; ALLEN, C. \& QUIRINO, B.F. 2012. Diversity of Brazilian biovar 2 strains of Ralstonia solanacearum Journal of General Plant Pathology 78:190-200.

SEN, Y.; FENG, Z.; VANDENBROUCKE, H.; VAN DER WOLF, J.; VISSER, R.G.F. \& VAN HEUSDEN, A.W. 2013. Screening for new sources of resistance to Clavibacter michiganensis subsp. michiganensis (Cmm) in tomato. Euphytica 190:309-317.

STEVENS, M.R.; LAMB, E.M. \& RHOADS, D.D. 1995. Mapping the Sw-5 locus for tomato spotted wilt virus resistance in tomatoes using RAPD and RFLP analyses. Theoretical and Applied Genetics 90:451-456.

STEVENS, M.R.; SCOTT, S.J. \& GERGERICH, R.C. 1991. Inheritance of a gene for resistance to tomato spotted wilt virus (TSWV) from Lycopersicon peruvianum Mill. Euphytica 59:9-17.

STRANGE, R.N. \& SCOTT, P.R. 2005. Plant disease: a threat to global food security. Phytopathology 43:83-116. 
SWANSON, J.K.; YAO, J.; TANS-KERSTEN, J. \& ALLEN, C. 2005. Behavior of Ralstonia solanacearum race 3 biovar 2 during latent and active infection of geranium. Phytopathology 95:136-143.

TAL, M. 1971. Salt tolerance in the wild relatives of the cultivated tomato: Responses of Lycopersicon esculentum, L. peruvianum, and L. esculentum minor to sodium chloride solution. Crop and Pasture Science 22:631-638.

VAKALOUNAKIS, D.J.; LATERROT, H.; MORETTI, A.; LIGOXIGAKIS, E.K. \& SMARDAS, K. 1997. Linkage between Frl (Fusarium oxysporum f. sp. radicis lycopersici resistance) and Tm- 2 (tobacco mosaic virus resistance-2) loci in tomato (Lycopersicon esculentum). Annals of applied biology 130:319-323.

VAN DER BIEZEN, E.A.; GLAGOTSKAYA, T.; OVERDUIN, B.; JOHN, H.; NIJKAMP, J. \& HILLE, J. 1995. Inheritance and genetic mapping of resistance to Alternaria alternata f. sp. lycopersici in Lycopersicon pennellii. Molecular and General Genetics 247:453461.

WANG, J.-F.; HO, F.-I.; TRUONG, H.T.H.; HUANG, S.-M.; BALATERO, C.H.; DITTAPONGPITCH, V. \& HIDAYATI, N. 2013. Identification of major QTLs associated with stable resistance of tomato cultivar 'Hawaii 7996'to Ralstonia solanacearum. Euphytica 190:241-252.

WANG, J.F.; HANSON, P. \& BARNES, J.A. 1998. Worldwide evaluation of an international set of resistance sources to bacterial wilt in tomato. In: PRIOR, P.; ALLEN, C. \& ELPHINSTONE, J. eds. Bacterial Wilt Disease.1 ed.Springer. Alemanha. p. 269-275.

YADESSA, G.B.; VAN BRUGGEN, A.H.C. \& OCHO, F.L. 2010. Effects of different soil amendments on bacterial wilt caused by Ralstonia solanacearum and on the yield of tomato. Journal of Plant Pathology 92:439-450.

YAGHOOBI, J.; YATES, J.L. \& WILLIAMSON, V.M. 2005. Fine mapping of the nematode resistance gene Mi-3 in Solanum peruvianum and construction of a S. lycopersicum DNA contig spanning the locus. Molecular Genetics and Genomics 274:60-69.

YAMAMOTO, S.; SHIRAISHI, S.; KAWAGOE, Y.; MOCHIZUKI, M. \& SUZUKI, S. 2015. Impact of Bacillus amyloliquefaciens S13- 3 on control of bacterial wilt and powdery mildew in tomato. Pest Management Science 71:722-727.

YOUNG, N.D.; ZAMIR, D.; GANAL, M.W. \& TANKSLEY, S.D. 1988. Use of isogenic lines and simultaneous probing to identify DNA markers tightly linked to the tm-2a gene in tomato. Genetics 120:579-585.

ZHAO, Y.; ZHANG, C.; CHEN, H.; YUAN, M.; NIPPER, R.; PRAKASH, C.S.; ZHUANG, W. \& HE, G. 2016. QTL mapping for bacterial wilt resistance in peanut (Arachis hypogaea L.). Molecular Breeding 36:1-11. 


\section{CAPÍTULO 4}

CARACTERIZAÇÃO DO CAFEEIRO (Coffea arabica - FAMÍLIA RUBIACEAE) COMO HOSPEDEIRO DE ISOLADOS DE Ralstonia pseudosolanacearum FILOTIPO I. 


\section{Caracterização do cafeeiro (Coffea arabica - família Rubiaceae) como hospedeiro de isolados de Ralstonia pseudosolanacearum filotipo I.}

\section{RESUMO}

O complexo de espécie de Ralstonia apresenta uma ampla gama de hospedeiros, podendo infectar mais de 250 espécies em 54 famílias botânicas, com frequentes novos relatos de novos hospedeiros ou novos variantes infectando hospedeiros já relatados. Níveis elevados de similaridade filogenética foram observados entre os genomas das famílias Rubiaceae e Solanaceae que se refletem no tamanho dos genomas, na organização cromossomal e na composição gênica. Devido a proximidade entre as duas famílias, e a grande quantidade de solanáceas hospedeiras do complexo de espécies de Ralstonia, esse trabalho teve como objetivo avaliar a espécie Coffea arabica como um possível hospedeiro deste grupo de patógenos. Três cultivares de C. arabica (Catuaí, Catuaí vermelho e Catuaí amarelo) foram inoculadas com nove isolados do complexo de espécies de Ralstonia. As plantas de tomateiro suscetível 'San Vito' (usadas com controle suscetível) murcharam rapidamente, enquanto que as plantas de cafeeiro levaram até 2 semanas para iniciar a expressão de sintomas. Os sintomas não foram somente de murcha verde, uma vez que ocorreu necrose de folhas cotiledonares, nanismo, perda de brilho e turgidez de folhas mais velhas além de necrose das mesmas. Somente um subgrupo de isolados da espécie $R$. pseudosolanacearum (raça 1/biovar 3/filotipo I) foram capazes de induzir sintomas no cafeeiro. A capacidade desses isolados em infectar o cafeeiro levanta a espécie R. pseudosolanacearum como possível ameaça à cultura do cafeeiro no Brasil.

Palavras-chave: café, Ralstonia pseudosolanacearum, suscetível, patogenicidade. 


\title{
Characterization of coffee (Coffea arabica - family Rubiaceae) as a host of Ralstonia pseudosolanacearum phylotype I isolates
}

\begin{abstract}
The Ralstonia solanacearum species complex presents a wide range of hosts, capable of infecting over 250 species in 54 botanic families with frequent new reports of new hosts or new strains infecting already reported hosts. Phylogenetic similarities were observed between the genomes of Rubiaceae and Solanaceae families, including genome size, cromossomal organization and genomic architecture. Due to the close relationship of both botanic families in association with the large number of solanaceous species that are hosts of the Ralstonia species complex, this chapter had as an objective to explore the potential of Coffea arabica as a host of this group of pathogens. Thee cultivars of C. arabica (Catuaí, Catuaí vermelho, and Catuaí amarelo) were inoculated with nine isolates from the $R$. solanacearum species complex. The susceptible tomato plants 'San Vito' (used as susceptible control) displayed wilting symptoms in a short period of time, while coffee plants took two weeks to initiate symptom expression. The symptoms in C. arabica were not only the usual wilt but also necrosis of cotyledonal leaves, dwarfism, and dull green color on the upper surface of older leaves associated with partial leaf necrosis (similar to that induced by water stress). Only a subgroup of $R$. pseudosolanacearum (race 1/biovar 3/phylotype I) isolates were capable of inducing symptoms on coffee plants. The capacity of those isolates on infecting coffee indicates that $R$. pseudosolanacearum might be a possible threat for the coffee crop under Brazilian conditions.
\end{abstract}

Keywords: coffee, host range, Ralstonia pseudosolanacearum and pathogenicity. 


\section{INTRODUÇÃO}

O cafeeiro (Coffea arabica e C. canephora - família Rubiaceae) é uma importante ‘commodity’ no Brasil. Segundo o MAPA (2016) (Ministério da Agricultura, Pecuária e Abastecimento), o país tem uma área cultivada de 2,25 milhões hectares e 287 mil produtores distribuídos em 15 Estados. Em 2015 o Brasil manteve sua posição como maior produtor e exportador de café do mundo, considerado o segundo maior consumidor. O café arábica $(C$. arabica) é cultivado principalmente sob temperaturas mais amenas, com média entre $19^{\circ} \mathrm{C}-$ $22^{\circ} \mathrm{C}$ e em 2015 alcançou a produção de 32,05 milhões de sacas, superior aos 11,19 milhões de café conilon (C. canephora), geralmente cultivado em regiões mais quentes com temperatura média entre $22^{\circ} \mathrm{C}-26^{\circ} \mathrm{C}$ (Nunes et al., 2005; Ricci \& Neves, 2006; MAPA, 2016).

Diversas doenças de etiologia fúngica têm sido descritas afetando o cafeeiro no Brasil como, por exemplo, a ferrugem, cercosporiose, mancha-de-phoma, mancha-de-ascochyta, mancha aureolada, rizoctoniose, roseliniose, mancha anular e amarelinho (Carvalho \& Chalfoun, 2000). Entre os patógenos bacterianos, pode-se citar Burkholderia andropogonis, agente causal da doença 'mancha foliar' (Gonzalez et al., 2007) e Pseudomonas syringae pv. garcae (Rodrigues et al., 2015).

O que atualmente é conhecido como complexo de espécies de Ralstonia (CER) foi inicialmente dividido em raças (Buddenhagen et al., 1962), biovares (Hayward, 1991), filotipos e sequevares (Fegan \& Prior, 2005). No Brasil são encontradas as espécies $R$. solanacearum, previamente conhecida como os isolados de filotipo II e $R$. pseudosolanacearum que corresponde aos filotipos I e III, (Santiago et al., 2016). Até o presente momento, apenas isolados do filotipo I têm sido relatados no país (Rodrigues et al., 2011; Santiago et al., 2016). Esse complexo de espécies existe em regiões tropicais e subtropicais, com dispersão por todos os estados brasileiros (Elphinstone, 2005; Lopes, 2005) e elevado risco para produtores de diferentes espécies hospedeiras já relatadas. 
O CER apresenta uma ampla gama plantas de hospedeiras, infectando mais de 250 espécies em 54 famílias botânicas (Prior et al., 2016). Novos relatos de plantas hospedeiras são frequentes na literatura como, por exemplo, os registros de doenças em espécies ornamentais (Weibel et al. (2016), rúcula (Albuquerque et al., 2016) e figo (Jiang et al. (2016), causadas por membros do complexo, demonstrando o potencial infectivo desse complexo (Genin, 2010).

As espécies hospedeiras mais conhecidas do CER pertencem à família Solanaceae, como o tomate, batata, pimentas (Capsicum) e berinjela (Elphinstone, 2005). Existe também um grupo de hospedeiras "não tradicionais" que foram relatadas no Brasil, tais como: eucalipto (Eucalyptus spp.), rúcula (Eruca sativa), abóbora (Cucurbita spp.), pepino (Cucumis sativus), feijão (Phaseolus vulgaris), cariru, maracujá (Passiflora edulis) e pimenta longa (Piper hispidinervium) (Akiba et al., 1980; Dristig et al., 1988; Parente et al., 1988; Lopes et al., 1997; Lopes et al., 1999; Lopes et al., 2001; Sinigaglia et al., 2001; Malavolta et al., 2008; Albuquerque et al., 2016).

Até o momento poucas rubiáceas foram relatadas como suscetíveis ao patógeno, com registros se limitando a plantas invasoras como Oldenlandia corymbosa na Índia (Hayward, 1994) e a Borreria alata na Colômbia (Romo, 2012). No Brasil ainda não existem relatos de infecções pelo CER em rubiáceas (Malavolta et al., 2008).

Em um estudo realizado por Lin et al. (2005), foi observado uma similaridade filogenética entre as famílias Rubiaceae e Solanaceae, com evidências de que o tomate e o café possam ter divergido entre 83 e 89 milhões de anos atrás (Guyot et al., 2012). Entre as evidências, encontrase um conjunto de similaridades entre as duas espécies, como tamanho de genoma, organização cromossomal e arquitetura genômica. A partir dessas observações de estreito relacionamento filogenético de tomateiro e do cafeeiro, uma hipótese plausível seria que o processo coevolutivo da potencial interação Coffea-Ralstonia, embora ainda não relatado em condições 
naturais, pode ter sido estabelecido antes mesmo das divergências evolucionárias entre as famílias Rubiaceae e Solanaceae. Neste contexto, o objetivo do presente estudo foi explorar a espécie $C$. arabica como possível hospedeira do CER e verificar a potencial ameaça da murcha bacteriana para o cultivo e para a indústria cafeeira do Brasil e do mundo.

\section{MATERIAL E MÉTODOS}

Três cultivares de C. arabica ('Catucaí', 'Catuaí Amarelo' e 'Catuaí Vermelho') foram selecionadas e propagadas via sementes em bandejas de poliestireno de 72 células preenchidas com substrato esterilizado. As plântulas de café foram mantidas em casa de vegetação até a germinação e formação das folhas cotiledonares, quando foi feita a inoculação (Figura 12). Plantas de tomateiro suscetível ('San Vito') foram propagadas por semente em bandeja de 128 células com substrato esterilizado e mantidas em casa de vegetação até o momento da inoculação quando a planta tinha três folhas verdadeiras.

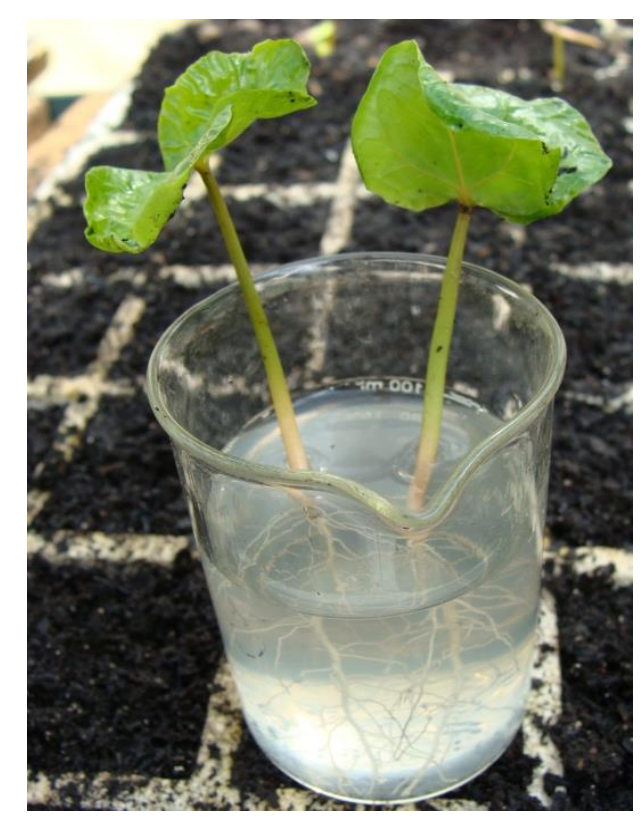

Figura 12. Plântulas de Coffea arabica em estágio de inoculação (com folhas cotiledonares) imersas em suspensão bacteriana de um isolado do complexo de espécies de Ralstonia. Foto: C. A. Lopes. 
Nove isolados do CER com diferentes origens geográficas e de diferentes hospedeiros (Tabela 13) foram selecionados para inoculação nas mudas de cafeeiro. Os isolados foram cultivados em meio CPG com modificações, substituindo a sacarose pelo glicerol, e mantidos em câmara de crescimento por 48 horas a $28^{\circ} \mathrm{C}$. Colônias típicas foram repicadas para outras placas e mantidas pelo mesmo período em câmara de crescimento. O inóculo foi produzido pela raspagem das colônias das placas com meio, suspensas em água comum, homogeneizadas e calibradas por espectrofotômetro para a concentração de $10^{8} \mathrm{UFC} / \mathrm{mL}$.

Para a inoculação, as plantas foram removidas das bandejas, o substrato removido do sistema radicular por lavagem das raízes, o terço inferior da raiz foi cortado e então imerso em suspensão bacteriana de cada isolado por 1 minuto. Após a inoculação as plantas foram transplantadas para vasos de plástico de $1 \mathrm{~L}$ com solo autoclavado e mantidas em casa de vegetação com temperatura entre 20 e $40^{\circ} \mathrm{C}$ e com aquecimento suplementar noturno, visando minimizar a frequência de escapes. Foram inoculadas 10 plantas de cafeeiro por cultivar por isolado, 10 plantas de tomateiro por isolado e, como controle das condições ambientais, 10 plantas de cafeeiro e 10 de tomateiro foram "inoculadas" apenas com água. O delineamento experimental foi inteiramente casualizado com duas repetições de cinco plantas por cultivar por isolado.

O método de avaliação utilizado foi de contagem de plantas murchas e uma média foi gerada para cada cultivar/isolado. Outros sintomas também foram avaliados devido ao não conhecimento de respostas que possam ser geradas pela infecção por isolados do CER nesta hospedeira.

\section{RESULTADOS}

As plantas de tomateiro 'San Vito' (controle suscetível) murcharam rapidamente, confirmando a virulência de todos isolados. Nenhuma planta do controle negativo (água) 
apresentou qualquer tipo de sintomas. As condições ambientais também foram favoráveis para o desenvolvimento da doença. Alguns dos sintomas observados nas plantas de café foram diferentes daqueles encontrados no tomateiro (caracterizados pela típica presença de 'murcha verde') (Figura 13). Os seguintes sintomas foram observados em plantas de cafeeiro: (1) murcha e seca de uma ou ambas folhas cotiledonares, com morte das plantas no segundo caso; (2) perda de turgidez, com perda de brilho na face adaxial foliar; (3) epinastia, redução do crescimento sem murcha aparente. Duas semanas após a inoculação, 40 a $67 \%$ das plantas de café apresentaram sintomas quando inoculadas com os isolados CNPH-RS 322, CNPH-RS 359 e CNPH-RS 376, todos pertencentes ao filotipo I, atualmente classificados como $R$. pseudosolanacearum (Tabela 13).

As plantas sintomáticas foram avaliadas quanto a exsudação de fluxo bacteriano, apresentando grande volume do mesmo. A partir do fluxo bacteriano foi feito o isolamento e bactérias brancas de aparência típica de isolados do CER foram obtidas. Em seguida foram inoculadas em plantas de tomateiro 'San Vito' que então apresentaram sintomas claros de murcha. Os isolados foram mais agressivos nas plantas de tomate, induzindo sintomas em cinco dias comparados aos 15 que levou para o café. A cultivar 'Catucaí' apresentou sintomas mais rapidamente que a 'Catuaí Amarelo' e 'Catuaí Vermelho' 
Tabela 13. Porcentagem de plantas murchas de Coffea arabica 'Catucaí', 'Catuaí Amarelo' e 'Catuaí Vermelho' (média das três cultivares) e de plantas de tomateiro 'San Vito' inoculados por imersão de raízes podadas em suspensão bacteriana de nove diferentes isolados de origens e hospedeiras diferentes.

\begin{tabular}{cccccc}
\hline Isolado & $\begin{array}{c}\text { Biovar/ } \\
\text { Filotipo }\end{array}$ & $\begin{array}{c}\text { Hospedeira } \\
\text { original }\end{array}$ & Cidade-Estado & $\begin{array}{c}\text { Café } \\
(\%)^{3}\end{array}$ & $\begin{array}{c}\text { Tomate } \\
(\%)\end{array}$ \\
\hline CNPH-RS 210 & 1/II & Banana & Manaus - Amazonas & 0 & 0 \\
CNPH-RS 217 & 1/II & Chicória & Santa Isabel - Pará & 0 & 100 \\
CNPH-RS 221 & 1/II & Tomate & Brasília - Distrito Federal & 0 & 100 \\
CNPH-RS 252 & $2 /$ II & Batata & Contenda - Paraná & 0 & 20 \\
CNPH-RS 265 & $1 /$ II & Eucalipto & Eunápolis - Bahia & 0 & 80 \\
CNPH-RS 322 & 3/I & Tomate & Fortaleza do Tabocão - & 67 & 100 \\
CNPH-RS 329 & 3/I & Jiló & Tocantins & 0 & 100 \\
CNPH-RS 359 & 3/I & Berinjela & Matinha -Tocantins & 0 \\
CNPH-RS 376 & 3/I & Tomate & Sinop - Mato Grosso & 40 & 100 \\
\hline
\end{tabular}




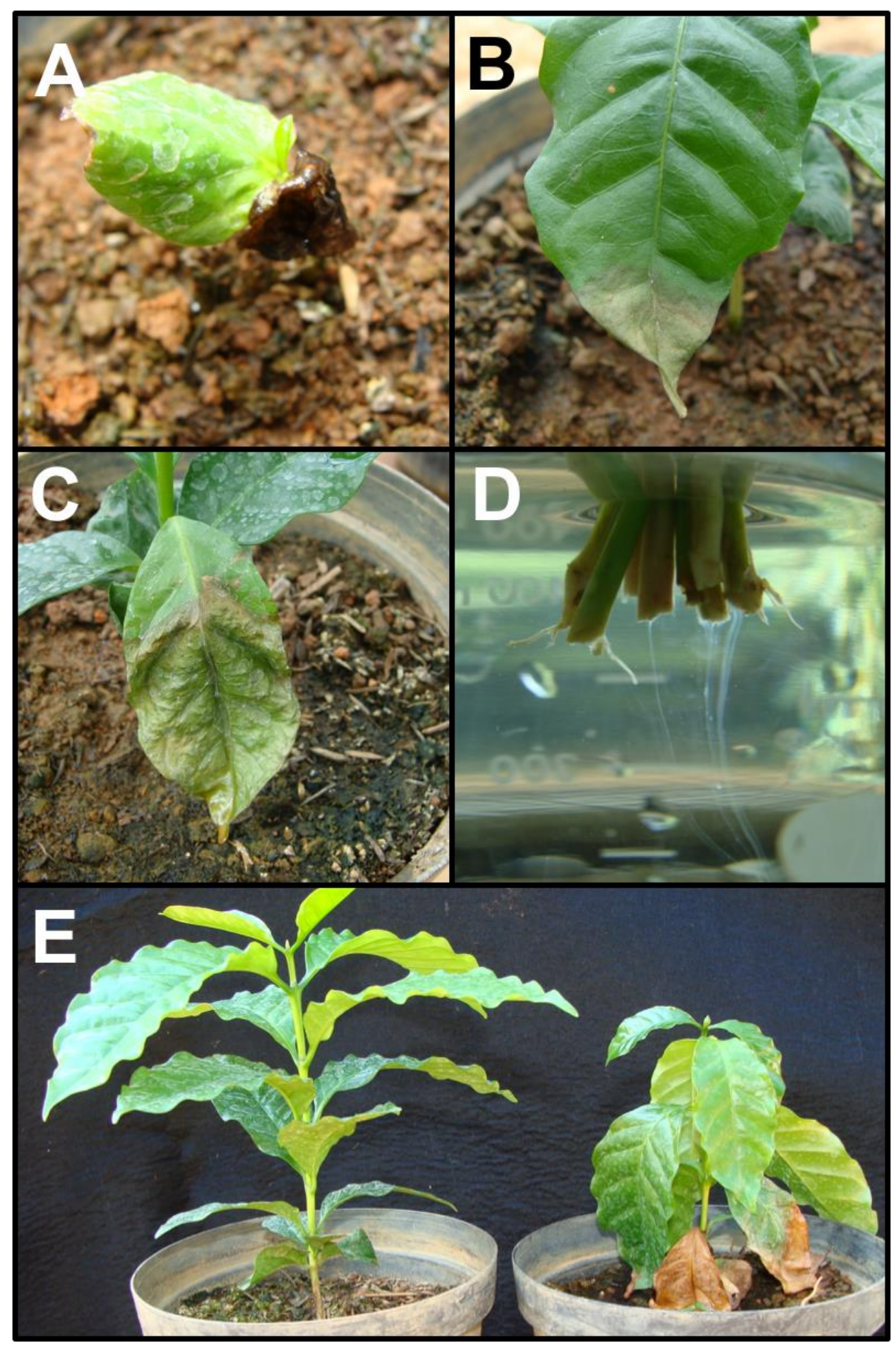

Figura 13. Sintomas de murcha bacteriana em plantas de cafeeiro Coffea arabica. (A) Necrose de uma das folhas cotiledonares; (B) Perda de turgidez e brilho da face adaxial foliar; (C) Evolução da perda de turgidez seguido de início de necrose da folha; (D) Fluxo bacteriano exsudando de caules seccionados de plantas de cafeeiro infectadas e sintomáticas; (E) À esquerda uma planta não inoculada e à direita planta inoculada com isolado do complexo de 
espécies de Ralstonia apresentando sintomas de murcha verde também com necrose em folhas mais velhas. Fotos: C. A. Lopes.

\section{DISCUSSÃO}

Os tipos de sintomas encontrados, como necrose de bordos foliares e perda do brilho da face adaxial indicam sintomas de estresse hídrico, foram condizentes com o efeito físico de entupimento de vasos, induzido pelas colônias da bactéria (Huang \& Allen, 2000; Tans-Kersten et al., 2001). Além dos sintomas, as plantas apresentaram o fluxo bacteriano na realização do teste do copo, demonstrando a colonização dos vasos pela bactéria. Seis dos isolados não causaram sintomas em café, cinco deles do filotipo II, sendo um deles da raça 2 (banana) e os demais de variadas hospedeiras. Isolados da raça 2 são mais limitados na sua gama de hospedeiras.

Os isolados que causaram infecções em plântulas de café foram identificados exclusivamente como pertencentes ao filotipo I, atualmente $R$. pseudosolanacearum (Safni et al., 2014). Esse filotipo apresenta as maiores taxas evolutivas e a mais ampla distribuição geográfica (Lebeau et al., 2011; Wicker et al., 2012). Esses resultados levantam a possibilidade não de uma capacidade de causar infecção no cafeeiro do tipo filotipo-especifica, mas do tipo isolado-especifica, corroborando informações recentes de que seis de dez isolados do filotipo I causaram sintomas de murcha em acessos de café (dados não publicados).

O baixo número de plantas utilizadas nos ensaios impossibilita a inferência de níveis de resistência ou tolerância das cultivares. Em relação à comparação entre espécies de cafeeiro, trabalhos preliminares realizados pelo nosso grupo de pesquisa (dados não publicados) mostraram que acessos de C. canephora apresentam uma resposta similar de suscetibilidade à murcha bacteriana. Coffea canephora é uma espécie mais adaptada a temperaturas mais 
elevadas, o que permite inferir um maior risco dessa espécie sofrer, de maneira mais severa, perdas pela bactéria.

De acordo com o conceito de Kelman (1953), espécie hospedeira é aquela que apresenta sintomas de murcha em condições de campo e os mesmos sintomas devem ser reproduzidos em ensaios, usando inoculação artificial após isolamento do patógeno. Entretanto, para Alvarez et al. (2008), verdadeiras hospedeiras do CER devem permitir a colonização dos vasos do xilema e as espécies tolerantes seriam aquelas em que poucos ou ocasionais vasos são colonizados. Como até o momento não foram observados sintomas em cafeeiro no campo, segundo Kelman, o cafeeiro ainda seria uma espécie alternativa, podendo, por exemplo, ser empregada na rotação de culturas com espécies suscetíveis. Porém, com base nos resultados apresentados, tal rotação poderia levar ao aumento da população bacteriana e consequente pressão de seleção a favor de isolados capazes de infectar o cafeeiro. Mesmo aplicando o conceito de "tolerante" dado por Alvarez et al. (2008), o cafeeiro serviria como um potencial disseminador do patógeno, por meio de infecções latentes por viveiros de mudas contaminadas, similar ao ocorrido em algumas áreas de cultivo com eucalipto (Alfenas et al., 2009).

Confirmado a capacidade de $R$. pseudosolanacearum em causar murcha em mudas de cafeeiro, surge a necessidade de testes que visem a diagnose precoce, para evitar a disseminação do patógeno em áreas de cultivos dessa potencial hospedeira. Os sintomas similares aos de estresse hídrico podem levar a um diagnóstico equivocado, o que pode atrasar o estabelecimento de práticas de manejo que evitem potenciais perdas na cultura. Por ser uma doença vascular, os sistemas de diagnose frequentemente levam a destruição da amostra, como no caso do teste do copo ou outros que necessitem do sistema vascular central.

O aquecimento global é um assunto constante nos dias de hoje e suas consequências surgem mais fortemente a cada ano. Esse fenômeno eventualmente atingirá regiões produtoras 
de café, levando novos patógenos de clima tropical a afetar essa cultura, ou por adaptação ou simplesmente por fornecer melhor ambiente para o desenvolvimento dos mesmos.

Com modificações nas temperaturas mundiais citadas anteriormente, o CER poderá se tornar um problema em novas regiões onde previamente não podia se estabelecer, em especial, devido a sua temperatura ideal para sobrevivência e multiplicação entre $27^{\circ} \mathrm{C}$ a $35^{\circ} \mathrm{C}$ (Hayward, 1991). Para reduzir os riscos de perdas pelas mudanças climáticas, Savary et al. (2011) indicam a necessidade de antecipar o estabelecimento de potenciais epidemias. La Porta et al. (2008) destacam também a importância de identificar patógenos de elevado potencial destrutivo, tendo como objetivo alertar as autoridades e a sociedade cientifica sobre os riscos de eventuais epidemias.

Até o momento esse é o primeiro relato de infecção artificial do cafeeiro por $R$. pseudosolanacearum, expandindo a gama de hospedeiras desse patógeno. Mais recentemente, comparações genéticas de distintos isolados do CER indicaram que o grupo de genes envolvidos na gama de hospedeiras e virulência está evoluindo mais rapidamente que o genoma da bactéria como um todo (Remenant et al., 2010).

O presente trabalho evidencia o cafeeiro como um dos hospedeiros de $R$. pseudosolanacearum (filotipo I - biovar 3), podendo trazer uma ameaça em potencial para essa importante cultura e para o agronegócio do café, em especial em novas fronteiras geográficas que possam apresentar condições ambientais favoráveis a epidemias naturais. O melhoramento do cafeeiro tem entre suas linhas, o desenvolvimento de materiais genéticos com maior capacidade de produção em temperaturas mais elevadas, sendo recomendado também a busca por possíveis fontes de resistências a fitopatógenos de clima tropical, incluindo $R$. pseudosolanacearum. 


\section{CONCLUSÕES}

- O cafeeiro (C. arabica), é hospedeiro de R. pseudosolanacearum (filotipo I - biovar 3);

- Apenas isolados de R. pseudosolanacearum (filotipo I - biovar 3) foram capazes de infectar plântulas de cafeeiro, induzindo sintomas;

- O aparecimento de sintomas no cafeeiro é mais lento e sutil (nanismo e seca de folhas) do que aqueles observados em tomateiro, que é um hospedeiro natural de $R$. pseudosolanacearum (filotipo I - biovar 3);

- A ausência de sintomas típicos de murcha pode levar a equívoca diagnose da causa, reduzindo a possibilidade de controle do patógeno;

- Devido ao plantio do cafeeiro geralmente ocorrer em regiões de clima mais frio, possivelmente haja escape da infecção por R. pseudosolanacearum (filotipo I - biovar 3), porém, espécies de cafeeiro mais adaptadas a altas temperaturas (ex. C. canephora) poderão permitir o desenvolvimento de epidemias de murcha;

- A migração da cultura do cafeeiro rumo à Região Norte do país e o fenômeno de aquecimento global indicam que os programas de melhoramento genético da cultura devem levar em consideração a possível ameaça que venha representar a $R$. pseudosolanacearum (filotipo I - biovar 3) para a cafeicultura nacional.

\section{PERSPECTIVAS}

- Avançar na busca por variedades resistentes de C. canephora e C. arabica, visando estabelecimento de uma base genética para resistência a murcha bacteriana;

- Analisar geneticamente os isolados quanto à capacidade de infectar o cafeeiro, para identificar quais características genéticas estariam vinculadas a esse atributo;

- Procurar, em condições de campo plantas de cafeeiro com sintomas de murcha bacteriana similares aos induzidos nas condições experimentais empregadas no presente trabalho. 


\section{REFERENCIAS BIBLIOGRÁFICAS}

AKIBA, F.; KIMURA, O.; PIMENTEL, J.P.; RIBEIRO, R.L.D. \& ROBBS, C.F. 1980. Murcha bacteriana do feijão vagem: doença nova para o Brasil. Fitopatologia Brasileira 6:379.

ALBUQUERQUE, G.M.R.; SILVA, A.M.F.; SILVA, J.R.; SOUZA, E.B.; GAMA, M.A.S. \& MARIANO, R.L.R. 2016. First Report of Bacterial Wilt Caused by Ralstonia pseudosolanacearum on Eruca vesicaria subsp. sativa in Brazil. Plant Disease 100:2319.

ALFENAS, A.C.; ZAUZA, E.A.F.; MAFIA, R.G. \& ASSIS, T.F. 2009. Clonagem e doenças de eucalipto. 2 Ed. Editora UFV. Viçosa, MG.

ALVAREZ, B.; VASSE, J.; LE-COURTOIS, V.; TRIGALET-DÉMERY, D.; LÓPEZ, M.M. \& TRIGALET, A. 2008. Comparative behavior of Ralstonia solanacearum biovar 2 in diverse plant species. Phytopathology 98:59-68.

BUDDENHAGEN, I.W.; SEQUEIRA, L. \& KELMAN, A. 1962. Designation of races of Pseudomonas solanacearum. Phytopathology 52:726-730.

CARVALHO, V.L.D. \& CHALFOUN, S.M. 2000. Doenças do cafeeiro: diagnose e controle. 1 Ed. EPAMIG. Belo Horizonte.

DRISTIG, M.C.G.; DIANESE, J.C. \& TAKATSU, A. 1988. Characterization of Pseudomonas solanacearum isolated from Eucalyptus. Fitopatologia Brasileira 13:106-108.

ELPHINSTONE, J.G. 2005. The current bacterial wilt situation: a global overview. In: ALLEN, C.; PRIOR, P. \& HAYWARD, A.C. eds. Bacterial wilt disease and the Ralstonia solanacearum species complex.1 ed.APS Press. Estados Unidos. p. 9-28.

FEGAN, M. \& PRIOR, P. 2005. How complex is the Ralstonia solanacearum species complex? In: ALLEN, C.; PRIOR, P. \& HAYWARD, A.C. eds. Bacterial wilt disease and the Ralstonia solanacearum species complex.1 ed.APS Press. Estados Unidos. p. 449-461.

GENIN, S. 2010. Molecular traits controlling host range and adaptation to plants in Ralstonia solanacearum. New Phytologist 187:920-928.

GONZALEZ, C.F.; VENTURI, V. \& ENGLEDOW, A.S. 2007. The phytopathogenic Burkholderia. In: COENYE, T. \& VANDAMME, P. eds. Burkholderia: Molecular Microbiology and Genomics.1 ed.Horizon Scientific Press. Reino Unido. p. 153-176.

GUYOT, R.; LEFEBVRE-PAUTIGNY, F.; TRANCHANT-DUBREUIL, C.; RIGOREAU, M.; HAMON, P.; LEROY, T.; HAMON, S.; PONCET, V.; CROUZILLAT, D. \& DE KOCHKO, A. 2012. Ancestral synteny shared between distantly-related plant species from the asterid (Coffea canephora and Solanum sp.) and rosid (Vitis vinifera) clades. BMC Genomics 13:1-13. 
HAYWARD, A.C. 1991. Biology and epidemiology of bacterial wilt caused by Pseudomonas solanacearum. Annual Review of Phytopathology 29:65-87.

HAYWARD, A.C. 1994. The hosts of Pseudomonas solanacearum. In: HAYWARD, A.C. \& HARTMAN, G.L. eds. Pseudomonas solanacearum: The disease and its causative agent. 1 ed.CABI International. Reino Unido. p. 101-115.

HUANG, Q. \& ALLEN, C. 2000. Polygalacturonases are required for rapid colonization and full virulence of Ralstonia solanacearum on tomato plants. Physiological and Molecular Plant Pathology 57:77-83.

JIANG, Y.; LI, B.; LIU, P.; LIAO, F.; WENG, Q. \& CHEN, Q. 2016. First report of bacterial wilt caused by Ralstonia solanacearum on fig trees in China. Forest Pathology 46:256258.

KELMAN, A. 1953. The bacterial wilt caused by Pseudomonas solanacearum. In. Raleigh: North Carolina Agricultural Experiment Station, 194.

LA PORTA, N.; CAPRETTI, P.; THOMSEN, I.M.; KASANEN, R.; HIETALA, A.M. \& VON WEISSENBERG, K. 2008. Forest pathogens with higher damage potential due to climate change in Europe. Canadian Journal of Plant Pathology 30:177-195.

LEBEAU, A.; DAUNAY, M.-C.; FRARY, A.; PALLOIX, A.; WANG, J.-F.; DINTINGER, J.; CHIROLEU, F.; WICKER, E. \& PRIOR, P. 2011. Bacterial wilt resistance in tomato, pepper, and eggplant: genetic resources respond to diverse strains in the Ralstonia solanacearum species complex. Phytopathology 101:154-165.

LIN, C.; MUELlER, L.A.; MC CARTHY, J.; CROUZILlAT, D.; PETIARD, V. \& TANKSLEY, S.D. 2005. Coffee and tomato share common gene repertoires as revealed by deep sequencing of seed and cherry transcripts. Theoretical and Applied Genetics 112:114-130.

LOPES, C.A. 2005. Murchadeira da batata. 1 Ed. Associação Brasileira da Batata. Itapetininga.

LOPES, C.A.; POLTRONIERI, L.S.; ALBUQUERQUE, F.C. \& TRINDADE, D.R. 1997. A murcha bacteriana em pimenta longa. Horticultura Brasileira resumo 140.

LOPES, C.A.; POLTRONIERI, L.S. \& POLTRONIERI, M.C. 2001. Cariru, nova hospedeira de Ralstonia solanacearum. Horticultura Brasileira Resumo 19.

LOPES, C.A.; POLTRONIERI, L.S.; QUEZADO-SOARES, A.M.; TRINDADE, D.R. \& ALBUQUERQUE, F.C. 1999. Maracujazeiro, mais um hospedeiro de Ralstonia solanacearum. Summa Phytopathologica 25.

MALAVOLTA, J.; BERIAM, L.; ALMEIDA, I.; RODRIGUES NETO, J. \& ROBBS, C. 2008. Bactérias fitopatogênicas assinaladas no Brasil: uma atualização. Summa Phytopathologica 34:9-87. 
MAPA 2016. O cafeeiro no Brasil [http://www.agricultura.gov.br/vegetal/culturas/cafe/saibamais] Consultado em 05/07/2016.

NUNES, A.M.L.; SOUZA, F.F.; COSTA, J.N.M.; SANTOS, J.C.F.; PEQUENO, P.L.; COSTA, R.S.C. \& VENEZIANO, W. 2005. Cultivo do Café Robusta em Rondônia. Sistemas de Produção 5 [http://sistemasdeproducao.cnptia.embrapa.br/] Consultado em 05/05/2016.

PARENTE, P.M.G.; TAKATSU, A. \& LOPES, C.A. 1988. Ocorrência de Pseudomonas solanacearum em pepino. Horticultura Brasileira Resumo 25.

PRIOR, P.; AILLOUD, F.; DALSING, B.L.; REMENANT, B.; SANCHEZ, B. \& ALLEN, C. 2016. Genomic and proteomic evidence supporting the division of the plant pathogen Ralstonia solanacearum into three species. BMC Genomics 17:90-101.

REMENANT, B.; COUPAT-GOUTALAND, B.; GUIDOT, A.; CELLIER, G.; WICKER, E.; ALLEN, C.; FEGAN, M.; PRUVOST, O.; ELBAZ, M. \& CALTEAU, A. 2010. Genomes of three tomato pathogens within the Ralstonia solanacearum species complex reveal significant evolutionary divergence. BMC Genomics 11:379-395.

RICCI, M.S.F. \& NEVES, M. 2006. Cultivo do Café Orgânico [http://sistemasdeproducao.cnptia.embrapa.br/FontesHTML/Cafe/CafeOrganico_2ed/in dex.htm. ] Consultado em 02/05/2016.

RODRIGUES, L.M.R.; DESTÉFANO, S.A.L.; DINIZ, M.C.T.; R., C. \& RODRIGUES NETO, J. 2011. Pathogenicity of Brazilian strains of Ralstonia solanacearum in Strelitzia reginae seedlings. Tropical Plant Pathology 36:409-413.

RODRIGUES, L.M.R.; QUEIROZ-VOLTAN, R.B. \& GUERREIRO FILHO, O. 2015. Anatomical changes on coffee leaves infected by Pseudomonas syringae pv. garcae. Summa Phytopathologica 41:256-261.

ROMO, J.P. 2012. Identification of new hosts for Ralstonia solanacearum (Smith) race 2 from Colombia. Revista de Protección Vegetal 27:151-161.

SAFNI, I.; CLEENWERCK, I.; DE VOS, P.; FEGAN, M.; SLY, L. \& KAPPLER, U. 2014. Polyphasic taxonomic revision of the Ralstonia solanacearum species complex: proposal to emend the descriptions of Ralstonia solanacearum and Ralstonia syzygii and reclassify current $R$. syzygii strains as Ralstonia syzygii subsp. syzygii subsp. nov., $R$. solanacearum phylotype IV strains as Ralstonia syzygii subsp. indonesiensis subsp. nov., banana blood disease bacterium strains as Ralstonia syzygii subsp. celebesensis subsp. nov. and $R$. solanacearum phylotype I and III strains as Ralstonia pseudosolanacearum sp. nov. International Journal of Systematic and Evolutionary Microbiology 64:3087-3103.

SANTIAGO, T.R.; LOPES, C.A.; CAETANO-ANOLLÉS, G. \& MIZUBUTI, E.S.G. 2016. Phylotype and sequevar variability of Ralstonia solanacearum in Brazil, an ancient center of diversity of the pathogen. Plant Pathology. 
SAVARY, S.; NELSON, A.; SPARKS, A.H.; WILLOCQUET, L.; DUVEILLER, E.; MAHUKU, G.; FORBES, G.; GARRETT, K.A.; HODSON, D. \& PADGHAM, J. 2011. International agricultural research tackling the effects of global and climate changes on plant diseases in the developing world. Plant Disease 95:1204-1216.

SINIGAGLIA, C.; LOPES, M.; ALMEIDA, I.M.G. \& RODRIGUES NETO, J. 2001. Bacterial wilt of summer squash (Cucurbita pepo) caused by Ralstonia solanacearum in the State of São Paulo, Brazil. Summa Phytopathologica 27:251-253.

TANS-KERSTEN, J.; HUANG, H. \& ALLEN, C. 2001. Ralstonia solanacearum needs motility for invasive virulence on tomato. Journal of bacteriology 183:3597-3605.

WEIBEL, J.; TRAN, T.M. \& BOCSANCZY, A.M. 2016. A Ralstonia solanacearum Strain from Guatemala Infects Diverse Flower Crops, Including New Asymptomatic Hosts Vinca and Sutera, and Causes Symptoms in Geranium, Mandevilla Vine, and New Host African Daisy (Osteospermum ecklonis). Plant Health Progress 17:114.

WICKER, E.; LEFEUVRE, P.; DE CAMBIAIRE, J.-C.; LEMAIRE, C.; POUSSIER, S. \& PRIOR, P. 2012. Contrasting recombination patterns and demographic histories of the plant pathogen Ralstonia solanacearum inferred from MLSA. The ISME Journal 6:961974. 


\section{CONCLUSÕES GERAIS}

- O isolado CNPH-RS 488 Ralstonia solanacearum, capaz de suplantar a resistência da linhagem 'Hawaii 7996' é mais agressivo e apresenta capacidade de murchar também as espécies berinjela e jiló. Não sendo possível explicar tal capacidade por meio da quantificação de exopolissacarídeo ou biofilme;

- O meio semi-seletivo SMART limitou o crescimento de isolados brasileiros das biovares 1, 2A e 2T do complexo de espécies de Ralstonia, não sendo recomendado seu uso para isolamento de isolados desse complexo;

- A estratégia de bulk segregant analysis associado com o desenho de primers SCAR e o sistema de marcadores RAPD permitiu a identificação de um conjunto de primers informativos para as biovares 1 e 2A do complexo de espécies de Ralstonia;

- A estratégia de subtração in silico usando genomas completos de isolados do complexo de espécies de Ralstonia permitiu o desenvolvimento de um par de primers especifico para o gene sorbitol desidrogenase (pols), que, no presente estudo, está presente somente nos isolados de biovar 3.

- Um subgrupo de genótipos de Solanum peruvianum apresentou potencial para uso em programas de melhoramento do tomateiro visando resistência à murcha bacteriana devido à sua resistência superior que a linhagem resistente 'Hawaii 7996'.

- O cafeeiro (C. arabica), quando artificialmente inoculado em casa de vegetação, se mostrou ser hospedeiro apenas de isolados de R. pseudosolanacearum. 